\title{
MÁS Y NUEVOS DESTELLOS DE VICO EN PERIÓDICOS ESPAÑOLES DURANTE LA RESTAURAGIÓN (1885-1902): DE LA REGENGIA DE MARÍA GRISTINA AL GOMIENZO DEL REINADO DE ALFONSO XIII. [Adenda V a El Espejo de la Época]
}

\author{
José M. Sevilla \\ (Universidad de Sevilla)
}

A Antonio Heredia Soriano y José Luis Mora García, maestros de hispanismo filosófico.

RESUMEN: Continuación de los anteriores trabajos añadidos al estudio sobre la recepción de Vico en la prensa española del siglo XIX. Esta quinta entrega recorre en la historia y en la cultura de España, a partir de la muerte del rey Alfonso XII, la continuación de la Restauración monárquica con la regencia de María Cristina desde 1885 hasta el advenimiento del reinado de Alfonso XIII en 1902.

Palabras Clave: Vico, Hispanismo, Historia de España, Restauración Borbónica, Periódicos, Adendas a El espejo de la Época. Capítulos sobre G. Vico y la cultura hispánica (1735-2005) (Nápoles, 2007).

ABSTRACT: A continuation of the previous works added to the study on Vico's reception in the Spanish press of the 19th Century. This fifth addendum covers the continuation of the monarchical Restoration -through the history and the culture of Spain from the death of king Alfonso XII- with the regency of María Cristina from 1885 until the advent of king Alfonso XIII in 1902.

KEY Words: Vico, Hispanism, History of Spain, Bourbon Restoration, Newspapers, Addenda to The Mirror of the Time. Chapters on G. Vico and Hispanic Culture (1735-2005) (book in spanish, Naples 2007).

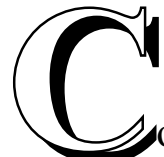

on la presente Adenda $\mathrm{V}$ aportamos algunas indagaciones más a la serie de las hasta ahora anejadas a El espejo de la época. Capítulos sobre

Texto original e inédito propuesto para su publicación por el Autor y superados los criterios de valoración y del proceso de aceptación requeridos, incluido reconocimiento externo por especialistas. 
G. Vico y la cultura hispánica (1737-2005). ${ }^{1}$ Entre estas adendas, ${ }^{2}$ hace ya un par de años que hemos complementado algunos aspectos del periodo recorrido entre 1840 y 1940, investigados y articulados para la contribución al volumen de Rocinante. Rivista di filosofia e cultura iberica e iberoamericana (2018), homenaje por el $350^{\circ}$ Aniversario de Vico, aunque hasta la fecha sin haber visto aún la luz. ${ }^{3}$ Hay también artículos de prensa y referencias de interés para este periodo ya expuestos y analizados por nosotros en otro cercano estudio por la celebración del aniversario viquiano, esta vez en el Bollettino del Centro di Studi Vichiani. ${ }^{4}$ En este último nos hemos centrado en la recepción de Vico en la derecha española a través de periódicos diarios o semanarios comprendidos entre 1902, mayoría de edad de Alfonso XIII y final de la Regencia, y el inicio de la Guerra Civil española en julio de 1936. Más recientemente, en una contribución a la Società Filosofica Italiana, hemos ampliado nuestra investigación al periodo entre 1668 y 1885 , marcado por la Revolución Gloriosa, el Sexenio Revolucionario y el inicio de la Restauración. ${ }^{5}$ Es en ese contexto en el que ahora nos adentramos nuevamente siguiendo en el periodo comprendido desde 1885 hasta 1902 el ensanche de la línea de referencias, de citas y resúmenes de ideas y doctrinas del napolitano. Se advertirá, al igual que en los anteriores citados estudios, que la interpretación de Vico oscila entre aquella dicotomía ideológica

1. J.M. Sevilla, El espejo de la época. Capitulos sobre G. Vico y la cultura hispánica (1735-2005), pres. de G. Cacciatore y pról. de A. Heredia Soriano, La Città del Sole, Nápoles, 2007. Volumen de 676 páginas, inaugural de la colección Pensamiento Latino.

2. ID., «Destellos de Vico en revistas culturales y literarias españolas. Nuevos capítulos viquianos en la cultura española entre 1841 y 1936», Cuadernos sobre Vico, 30-31, 2016-2017 Volumen XXV Aniversario, pp. 349-384. Se trata de la ADENDA I a El espejo de la época, citado, cuyo trabajo está dedicado a revistas, no a prensa periódica diaria o semanal.

3. ID., «Ráfagas de Vico en la prensa diaria española del siglo XIX (1840-1868)», Rocinante. Rivista di Filosofia Iberica, Iberoamericana e Interculturales, ISPF-CNR, II, n. 11, 2018 (e.p.): volumen especial Le trame dell'ingegno. Vico nell'orizzonte della cultura iberica e iberoamericana, a cargo de G. CACCiatore, M. SANNA y A. Mascolo. Según información de los editores en 2019, volumen previsto de publicación impresa por Diogene Ed. (Nápoles) y en edición digital en http://www.rocinante.it/archivio . Este trabajo constituye la ADENDA III a El Espejo de la Época.

4. ID., «¿Un Vico monarquista? Su recepción derechista en la prensa española (1902-1936)», Bollettino del Centro di Studi Vichiani, n. 48, 2018, pp. 115-127. Es la ADENDA II a El Espejo de la Época.

5. ID., “"Aludir con la palabra Vico”. Nuevas ráfagas viquianas en la prensa periódica española durante el Sexenio Revolucionario (1868-1874) y la Restauración alfonsina (1874-1885)», Bollettino della Società Filosofica Italiana, nuova serie n. 228, sett.-dic. 2019, pp. 25-50. Volumen impreso por Carocci Ed. (Roma). La contribución constituye la ADENDA IV a El Espejo de la Época. 
apreciada croceanamente entre "católicos" y "liberales", ahora confrontación política entre tradicionalistas y progresistas o, más en la acción de modelo estatal, entre partidarios de la monarquía y partidarios de la república. ${ }^{6}$ En ese contexto histórico sobre el que acontecen los hechos durante el último cuarto del siglo decimonono y comienzos del siglo veinte, estos se despliegan girando entre dos ejes principales, coetáneos, que son la Restauración canovista ${ }^{7} \mathrm{y}$ la emergencia y asalto al poder de los partidos de izquierda. ${ }^{8}$

El periodo ahora delimitado y que en esta Adenda abordamos recorre en la historia y en la cultura de España el tramo histórico que va desde la muerte del rey Alfonso XII, la continuación de la Restauración monárquica con la regencia de María Cristina (1885-1902), hasta el inicio del reinado de Alfonso XIII. Se continuará en una próxima adenda el tramo compuesto por el reinado de Alfonso XIII (1902-1931), la dictadura de Primo de Rivera (1923-1930) y la II República (1931-1936), hasta el comienzo de la Guerra Civil (1936-1939).

Como en alguna otra adenda anterior, también en esta que estamos presentando sólo pretendemos relatar — según ya hemos dicho- :

6. Vid. J.M. SEVILLA, «¿Un Vico monarquista? Su recepción derechista en la prensa española (19021936)», cit., p. 115. Cfr. parte II de El espejo de la época, cit.: «La recepción de Vico en la cultura hispánica en el siglo XIX», pp. 73-201. Vid. ID., Material Didáctico Introductorio a las Áreas de Conocimiento de Filosofia, vol. 3. Pensamiento Hispánico. Fénix Editora, Sevilla, 2017: "Introducción al Curso de Ideas" (pp. 9-13) y parte última "IV. Tendencias de la filosofia española en el siglo XIX. Filosofía, ideología y política" (pp. 97-115). Versión en PDF en la página web de la Facultad de Filosofía de la Universidad de Sevilla: http://www.centro.us.es/filosofia/web/

7. El periodo de 1875 a 1923, o sea, desde la restauración de la monarquía en España con la figura de Alfonso XII llegando a España el día de Reyes tras haber sido proclamado el 29 de diciembre de 1874 por el general Arsenio Martínez Campos. El gran muñidor de la política española, Antonio Cánovas del Castillo, había escrito el Manifiesto de Shandurst en el que el 1 de diciembre el Borbón anunciaba su retorno como regente de España. El Dr. D. Pedro Pascual Martínez sintetiza el periodo de la Restauración canovista de modo informativo y periodístico, como una fotografía histórica: «Durante casi cincuenta años, el sistema diseñado por Antonio Cánovas del Castillo se sostuvo y permaneció con unas connotaciones prácticamente inalteradas, a pesar de las diversas crisis sufridas. El turnismo, el entendimiento en la cúpula de los partidos entre los grandes caciques, que eran, en rigor, los únicos a los que se puede calificar de caiques - lo mismo conservadores que liberales - , las corruptelas permanentes, el clientelismo, la ocupación de escaños en el Congreso de los Diputados que se quería presentar como el resultado auténtico y puro de unas elecciones hechas con toda limpieza y que con precisión de relojería cada bandazo repetía unos resultados turnantes-alternantes, y el mantener congeladas y sin dejar pasar de la raya a las aspiraciones de crecimiento de otros partidos que no fueran el conservador y el liberal, forman un entramado que no sufrió grandes variaciones a lo largo de toda la Restauración canovista.» (P. PAScual, Escritores y editores en la Restauración canovista (1875-1923), Ediciones de la Torre, Madrid, 1994, tomo I, p. 21).

8. En junio de 1879 nace el Partido Socialista Obrero Español. 
«la dinámica de esa imagen de Vico emergente como flashes entre las páginas de la prensa diaria, expandiendo su recepción, más allá de en pensadores e intelectuales, a una mente civil escindida bipolarmente en ideologías contrapuestas y enfrentadas entre derechas e izquierdas, a su vez también fragmentadas. No en vano en alguna prensa del s. XIX se distinguía tipológicamente entre "periódicos democráticos" y "periódicos reaccionarios"»."

Recordemos que finalizábamos la entrega IV, acogida en la sede del Bollettino della Società Filosofica Italiana, con el siguiente párrafo:

«En el devenir de la vida política y social española hay acontecimientos notables y de preocupación e inestabilidad durante el proceso de Restauración: al fallecer el rey el 25 de noviembre de 1885 sin continuidad en el trono, ejerce la regencia su esposa, María Cristina de Habsburgo, gestando en su vientre a quien reinará a los 16 años con el nombre de Alfonso XIII. En el Gobierno, Sagasta lidera hasta 1890 un periodo de reformas liberales dentro de la Restauración, iniciada con el acabamiento de la I República Española y que terminará al proclamarse la II República el 14 de abril de 1931. Otra imagen de curvatura circular, tal vez viquiana.

[Se continuará]».10

Continuamos, pues, ese relato de destellos viquianos en periódicos españoles en otro nuevo tramo, el que transita entre la muerte de un rey y el advenimiento al trono por otro.

\section{De la conciencia de siglo del error al inicio del fin de siglo. «Sale al encuentro Vico».}

Persiste en relación con Vico la imagen cíclica de la historia y la doctrina de los cursos y recursos históricos, como hace el abogado y político liberal Federico Schwartz (1851-1929) en la Semblanza histórica publicada

9. Del prefacio "De ráfagas y otros aires", párrafo inicial de nuestra Adenda III «Ráfagas de Vico en la prensa diaria española del siglo XIX (1840-1868)», Rocinante, ya citado.

10. ID., “Aludir con la palabra Vico”. Nuevas ráfagas viquianas en la prensa periódica española durante el Sexenio Revolucionario (16868-1874) y la Restauración alfonsina (1874-1885)», Bollettino della Società Filosofica Italiana, cit., pp. 46-47. 
por el Diario de Tortosa el 18 de septiembre de 1885 al referirse a que «No en vano el ilustre Vico ideó sus ricorsi ó vastas edades que, á modo de cerrado círculo, la humanidad en su marcha recorre indefectiblemente al través del tiempo y del espacio». ${ }^{11}$ Esa imagen de fatalismo asociada a Vico, tan persistente en la prensa decimonónica española, se sigue tras la muerte del monarca Borbón un mes antes de la Navidad de 1885. Así se contrasta al año después en una extensa y positiva reseña a cargo de Ildefonso López de Hediger (†1890), en el «periódico religioso» La Verdad de Manresa, del libro del Dr. Vilaseca y Rius en tres volúmenes en octavo Apuntes de Historia Universal, por un Graduado en Filosofia y Letras (Barcelona, 1885-1886). Aunque se trata una Historia, eso sí, que - siguiendo a De Maistre - el recensor considera prejuiciosamente «está llena de mentiras, como llenos de mentiras están casi todos los libros de este siglo, que bien pudiera llamarse el siglo del error». ${ }^{12} \mathrm{Y}$ así escribe el joven licenciado en Derecho, López de Hediger:

\begin{abstract}
«[...] hánse empeñado los historiadores en corromper la verdad, esa verdad que descansa sobre adamantinas inconmovibles columnas; $y$ han creído que dominaba todavía Satanás, en el mundo con todo su poder funesto, y que la Humanidad seguía hoy aquellas edades sucesivas ó ricorsi que diría Vico (2) durante las cuales pasaban las generaciones de una dominación á otra dominación, á cual más tiránica y opresora; y que era posible en nuestros dias poner en boca de los personajes históricos arengas fingidas como lo hicieron Tito Livio y Jenofonte; ó hablar y escribir sin freno y sin respeto á nada, cual aquellos implacables enemigos de la verdad, los sofistas griegos.» ${ }^{\mathbf{1 3}}$
\end{abstract}

11. Diario de Tortosa, a. IV, n. 1.028, 18 de noviembre de 1885, p. 1 c. 1 (al igual que la abreviatura "p." designa "página", la "c." significa "columna”) . Cfr. nuestra Adenda IV «"Aludir con la palabra Vico". Nuevas ráfagas viquianas ...», cit., p. 45. El mismo «Diario católico, de intereses comerciales y agrícolas», como reza en su cabecera, que el año anterior en la continuación de un reaccionario artículo en defensa del clericalismo frente al liberalismo, atribuye a la «escuela clerical» su verdadera visión «en la historia de los designios de la Providencia», y así esgrime que esta escuela «enseña con San Agustín y con Bossuet, que todos los hechos concurren en su final resultado al triunfo de Cristo, y avisa con Vico que la historia es la justificación de la Providencia» («Escuelas clericales y escuelas liberales» (Continuación), Diario de Tortosa, a. III, n. 694, 10 de diciembre de 1884, p. 1 cc. 2-3).

N.B.- En todas las citas de aquí en adelante mantendremos la ortografía original del texto citado. 12. La Verdad, a. I, n. 71, miércoles 15 de diciembre de 1886, p. 586 c. 1. La intervención sigue inmersa en la polémica acerca de las escuelas y los sistemas de enseñanza.

13. Ibid. En la cita (2) indica a pie de página: (2) «Principi di sciensa [sic] nuova.» Ildefonso López de 
En el mismo año otra referencia religiosa la ofrece un Viernes Santo, en el periódico católico La Unión (1882-1887) — con un sermón del ya tradicionalista Juan Donoso Cortés en portada-, el escritor extremeño Eugenio Fernández Hidalgo, “cruzado” para quien sólo «á la luz de la historia sagrada» se condiciona la elaboración de la filosofía de la historia «por genios tan excelsos» como San Agustín, Vico, Bossuet o Donoso. ${ }^{14}$

En las antípodas de estas perspectivas catolicistas se halla el semanario radical madrileño, eco del espíritu republicano y revolucionario del Sexenio Democrático (1868-1874), Las Dominicales del Libre Pensamiento (18831909). En un ejemplar en honor de Giordano Bruno, con colaboraciones de conocidos ilustres republicanos y librepensadores, se reproduce traducida la «opinión» del francés Christian Bartholmess (1815-1856) sobre «numerosas afinidades» entre el nolano y el napolitano. Igual que pocos meses después, en el mismo semanario racionalista y librepensador, el poeta J. López Pérez empareja a Vico y Voltaire en su poema Excelsior, en memoria de su amigo C.J. Espinosa. ${ }^{15}$ Mientras que, también progresista, reluce entre anuncios de corsés, chocolates y cafés, dentistas a precios populares, reconstituyentes y linimentos, un relámpago viquiano a pie de la última página del diario federalista La República, del jueves 8 de octubre de 1885, en una entrega del poema en prosa La pitié suprême (pub. 1879) del insigne Víctor Hugo (1802-1885), uno de los llamados 'poemas de combate' traducido al castellano por el famoso escritor y periodista Ángel Rodríguez Chaves (1849-1907) para la sección del «Folletín de la República». El afamado literato y político francés, fallecido unos meses atrás (como recordará para siempre su multitudinario funeral de

Hediger, Graduado en 1886 por la Universidad de Barcelona y doctor en Derecho por la Universidad Central (Examen especial de la pena de muerte considerada en el triple aspecto de la filosofia del derecho, de la historia del derecho y del derecho positivo español - 11-XI-1887). Fallecido muy joven, en 1890 (vid. nota Diario de Cataluña, 4 de septiembre de 1890), siendo redactor del periódico carlista y católico El Correo Catalán.

14. La Unión, viernes 3 de abril de 1885, p. 2 c. 3. Vid. nuestra Ad. IV «"Aludir con la palabra Vico". Nuevas ráfagas viquianas ...», ya citado, pp. 44-45. E. Fernández Hidalgo, natural de Coria (Cáceres), licenciado en Filosofía y Letras y en Derecho; siguió colaborando como redactor en La Unión Católica (1887-1899), periódico continuador de La Unión tras la escisión del mismo, y extremo más conservador del canovismo.

15. Respectivamente en Las Dominicales del Libre Pensamiento, a. III, n. extra, 17 de febrero de 1885, p. 6 c. 4; e ib., a. III n. 117, 3 de mayo de 1885, p. 4 c. 2-3. Veáse nuestra ya citada Ad. IV «"Aludir con la palabra Vico". Nuevas ráfagas viquianas ...», pp. 45-46, donde recogemos parte del poema, y anticipamos unos versos: «[...] y una antorcha que puso en su sendero. / Vico y Voltaire: lo eterno y lo imposible; / lo ciego y lo sensible; [...]» (n. 117 citado). 
Estado el 1 de junio bajo el Arco del Triunfo), interpela a los filósofos para que confronten la verdad del presente con la enseñanza de la historia, tal que adviertan la circularidad de un hoy y aquí que se debate entre el tradicionalismo catolicista y el progresismo indefinido y ciego:

«Sí; yo lo repito, id, filósofos, interrogad las leyes, las costumbres, los juicios, los viejos siglos sangrientos, esos testigos unánimes; cavad, revolved la historia, panteón de los crímenes; abrid ese sarcófago de las muertas dinastías, escrutad los atestados, sondead les [sic] trajedias, y arrojando á los grandes palacios los resplandores de los incendios, ¿qué halláis?» ${ }^{16}$

Insensatos «que han caído débiles y desnudos en el poder sin fondo» y de los que sólo queda apiadarse; tener lástima del implacable «opresor» que, sin embargo, por una cuasihegeliana dialéctica de la fatalidad es «el oprimido más sombrío», escribe quien de hijo de un general napoleónico pasaría a ser exiliado tras el golpe de Estado de Napoleón III. Dice el proscrito republicano:

«iQue el amor es frágil y el ódio persistente! ¿Y en virtud de qué ley ha de ser inexorable? ¡Cielo sombrío! ¡Es hermoso protestar, querer romper ese ananké, saltar por encima de esa desesperación! La áspera luz reaparece siempre sorda y helada! Ve, filósofo, prueba, subleva el pensamiento, la razón, la sabiduría humana, la claridad contra la noche, la fatalidad y el horror. Llama en tu ayuda esos santos motines, Job, los Esenios, Pilón, los Terapéuticos, Voltaire, Diderot, Vico, Beccaria. Siempre vuelve á aparecer Satán con el esclavo, siempre el infierno vomita, como un doble torrente de lava, al demonio en el cielo, sobre la tierra la esclavitud, el mal en el infierno, la desgracia aquí abajo. Compadecer á Jesús es bueno; pero compadecer á Barrabás es también justo. La grandeza resplandece en rehabilitar á Caifás, en consolar á Pilatos; la cumbre más alta de la virtud es aquella en que Sócrates, espirante, es bueno para Anitus.

¡Oh! Los que siembran la desolación son los más tristes.» ${ }^{17}$

También republicano comprometido, no menos reconocido que Hugo en su patria como intelectual y político demócrata-liberal, el gaditano univer-

16. V. Hugo, «La piedad suprema», La República. Diario Federal, a. II n. 528, Madrid, 8 de febrero de 1885 , p. 4 c. 2.

17. Ib., c. 4 . 
sal Emilio Castelar (1832-1899), exaltado por el propio poeta francés como «una de las más luminosas inteligencias que han esclarecido a nuestro siglo», ${ }^{18}$ no pocas veces se ha referido y citado a Vico en sus escritos y dis$\operatorname{cursos}^{19}$ sino que, además, ha adoptado incluso sus doctrinas. Rememórese, por ejemplo, su famoso Discurso leido ante la Academia española en la recepción pública del señor D. Emilio Castelar, el 25 de Abril de 1880, publicado en diversos lugares. ${ }^{20} \mathrm{Y}$ ahora —en el momento que referimosseis años después del famoso Discurso recuerda el orador gaditano de nuevo a Vico en su texto La blanca luna, recogido en el anuario Almanaque de La Ilustración (1874-¿?) para el año 1887. Ahí dice Castelar, motivado por el desengaño ante el contenido de una conferencia popular sobre la 'blanca luna', y refiriéndose a Vico entre admiración y crítica pro-progresista hacia la tesis principal de la obra maestra viquiana, ésta «tan olvidada hoy á pesar de su mérito»:

«Juan Bautista Vico incapacitaba en su profunda Ciencia nueva, tan leida en otro tiempo y tan olvidada hoy á pesar de su mérito, al hombre para conocer efectos de que no fuera él causa, y obras de que no fuera él autor. Mas, á la verdad, si hubiéramos de proclamar como cosas verdaderas y sabidas tan sólo aquellas experimentadas en nuestras observaciones y experiencias personales, diariamente recomenzaríamos trabajos ya concluidos por otros, y lo que ganáramos en certidumbre, habríamos de perderlo en sabiduría.» ${ }^{21}$

Uno de los veinticinco ilustres colaboradores - con un bosquejo biográfico sobre el Cardenal Cisneros - del número del citado volumen del Almanaque es el académico y ateneísta Luis Vidart Schuch (1833-1897), de cuya figura como también de sus numerosas recepciones de Vico ya hemos

18. Víctor Hugo en: El Fígaro. Diario liberal, científico, literario y algo más, a. II, n. 140, Madrid, 31 de mayo de 1880 , p. 1 c. 4 ; cfr. ib., p. 2 c. 2.

19. Cfr. Ad. IV «"Aludir con la palabra Vico". Nuevas ráfagas viquianas ...», cit., pp. 34-35, 39-40 y 43; y también el apdo. II en la Ad. III «Ráfagas de Vico en la prensa diaria ...», en Rocinante, también ya citado.

20. Ad. IV citada en n. supra, p. 39 n. 27.

21. «La Blanca Luna, por el Excmo. Sr. D. Emilio Castelar, individuo de número de la Real Academia española», Almanaque de la Ilustración, a. XIV, Est. Tip. "Sucesores de Rivadeneyra”, Madrid, 1886, pp. 72-80; cita p. 79 c. 2. [Errata en encabezado de página dice "Almanaque de la Ilustsación"]. Cfr. Ad. I «Destellos de Vico en revistas culturales y literarias españolas. ...», Cuadernos sobre Vico, cit., pp. 366367. 
dado referida cuenta en anteriores trabajos. ${ }^{22}$ En el verano de 1886, el matinal asturiano El Carbayon (1879-1936) del viernes 27 de agosto de 1886 recoge — publicado por entregas - el artículo del capitán de artillería anteriormente publicado en el número de julio por la «Revista literaria, científica y artística» La Ilustración Nacional (1886-1901), ${ }^{23}$ donde - transcribiendo las palabras del comandante Arturo Cotarelo (1840-1848) sobre el método de Juan de Madariaga en sus Reflexiones Militares - se lee que

«hay, pues, en el trabajo del autor signos característicos de que conoce la escuela de un maestro eminente en cuestiones de historia, áun cuando se rechace su especial sistema de edades, aquel que pasó casi desapercibido en su tiempo y que se llamaba Juan Bautista Vico». ${ }^{24}$

Juicio similar expresado por Vidart al año siguiente en el extremeño republicano progresista La Crónica («Periódico democrático, de intereses morales y materiales», 1870-1892), ${ }^{25}$ diario que, por su interés para sus lectores, reproduce «con mucho gusto» el «último trabajo del distinguido escritor» en El Liberal (1879-1939). Bajo el título de «La historia militar de España», Vidart reseña un libro sobre historia de la artillería española en los siglos XIV-XV, del también comandante artillero José Arántegui, al que considera «uno de los más eruditos historiadores de la milicia española, y de la ciencia de la guerra». ${ }^{26}$ Escribe Vidart:

22. Así en nuestro citado volumen El espiritu de la época, pp. 125-129; y posteriormente en la Adenda I, también citada, pp. 358-360 y notas en pp. 379-380; y en el apdo. II de la también citada Ad. III «Ráfagas de Vico en la prensa diaria ...».

23. L. VIDART, «El autor de las 'Reflexiones Militares' y sus biógrafos D. Juan de Madariaga y D. Máximo Fuentes Acevedo» (Continuación), La Ilustración Nacional, t. IV, a. VII, n. 20, Madrid, julio de 1886, pp. 317-318. Cfr. Ad. I citada «Destellos de Vico en revistas culturales y literarias españolas. ...», pp. 359-360 y nn. 48-51 en pp. 379-380.

24. ID., «El autor de las 'Reflexiones Militares' y sus biógrafos D. Juan de Madariaga y D. Máximo Fuentes Acevedo» (Continuación), El Carbayon, a. VIII, n. 1673, Oviedo, 27 de agosto de 1886, p. 1 c. 3. Gfr. La Ilustración Nacional, cit., p. 318. Sobre Cotarelo, vid. Ad. I «Destellos de Vico en revistas culturales y literarias españolas. ...», cit., nota 49 en p. 379.

25. Periódico republicano correspondiente a la segunda época de Crónica de Badajoz (1864-1870) y al que siguió luego La Región Extremeña (1892-1920), que cambió de título varias veces con objeto de evitar suspensiones «especialmente a partir de señalarse afecto a las ideas de Salmerón» (MERCEDES Pulido, «La prensa extremeña en el tránsito del siglo XIX al XX», Revista de Estudios Extremeños, V, 54, n. 2, 1998, p. 740).

26. L. VIDART, «La historia militar de España», La Crónica, a. XXIII, n. 1.887, Badajoz, 8 de octubre 
«De los dos elementos que constituyen el conocimiento histórico, la erudicion que reune y clasifica los datos segun las reglas de la critica, y la reflexion razonada que procura estudiar el histórico en sus causas y en sus efectos, es el primer elemento que realmente se debe llamar Historia; porque el segundo suele transformarse en lo que el insigne Vico calificaba hace algunos siglos de ciencia nueva, y hoy conocemos con el nombre de filosofía de la historia. Y librenos Dios de condenar como perjudicial, ó cuando menos como inútil á la filosofía de la historia; pero es lo cierto que nada más sencillo que encerrarse en su gabinete de estudio, aguzar un poco el ingenio, y con ayuda de cuatro ideas de Hegel y dos de Krause, y alguna formulilla del positivismo que hoy priva, construir una síntesis en que se resumen toda la $\mathrm{h}[\mathrm{i}]$ storia de la humanidad, desde el mono-hombre, nuestro ilustre antepasado, hasta el hombre-mono de la Edad de Piedra, y el hombre sin cola y de orejas inamovibles que son las últimas perfecciones á que ha llegado nuestra naturaleza física. ${ }^{27}$

No sin hacer una concesión — en favor de la obra reseñada y de la metodología historiográfica de su autor - a la historia frente a la filosofía de la historia cuyas cualidades ha defendido otras veces igualmente identificada a la original, pero - siguiendo el prototipo interpretativo impuesto por Micheletdesconocida y nada influyente en su época, scienza nuova del napolitano, continúa escribiendo el hombre de libros y obuses:

"Queremos indicar con lo que acabamos de escribir, que entre perderse en los espacios imaginarios de la falsa filosofía de la historia, y seguir el camino de la concienzuda investigacion de los hechos, revolviendo archivos y bibliotecas, la eleccion no es dudosa; y el Sr. Arántegui ha procedido con gran cierto desdeñando el fácil renombre que puede adquirirse al tratar de asuntos históricos con un poco de imaginacion y un mucho de osadia, porque al fin y al cabo con razon se ha dicho, que la celebridad es la moneda falsa de la gloria, y el autor de los Apuntes históricos sobre la artillería española de los

de 1887, p. 2 c. 4 y p. 3 c. 1-2; cit. p. 2 c. 4 . Con la obra Apuntes historicos sobre la Artillería española en los siglos XIV y XV (1887), el comandante de artillería Jose Arántegui y Sanz ingresó en la Real Academia de la Historia; obra a la que siguen los Apuntes históricos sobre la Artilleria española en la primera mitad del siglo XVI (1891). Cfr. Fernando Pinto Cebrí́n, Ejército e historia. El pensamiento profesional militar español a través de la literatura castrense decimonónica, Tesis Doctoral (Facultad de Filosofía y Letras, Universidad de Valladolid, 2011, dirigida por la Dra. Da Elena Maza), Ministerio de Defensa, diciembre de 2013, NIPO: 083-13-202-3 (edición libro-e), n. 176 en p. 133.

27. L. VIDART, «La historia militar de España», La Crónica, cit., p. 2 c. 4. 
siglos $X I V$ y $X V$, es merecedor de más alto premio que el aplauso del vulgo y la fama de un día. ${ }^{28}$

En el diario de tendencia liberal dinástica El Constitucional (1880-?) de Gerona, el jurista y escritor salmantino Manuel Gil Maestre (1844-1912) recuerda la doctrina de la circularidad histórica de Vico, justo a propósito de una extensa crítica «á los adversartios del progreso constante ó indefinido, á los detractores de nuestro siglo; á los que ciegos partidarios de otras edades, condenan las conquistas y adelantos modernos». ${ }^{29}$ De tal modo que, combatiendo los idearios antiliberales y anarquistas en que «se reproduce la cruzada contra la emision libre del pensamiento», ${ }^{30}$ el magistrado de la Audiencia de Gerona sociológicamente se opone de cara a todos los contrarios a un Estado constitucional liberal, y de este modo también se enfrenta a políticos y poderosos que, ayer al igual que hoy, bajo el pretexto de regularizar «derechos indiscutibles», olvidan sus principios,

«prepondera la osadía, y se fomenta el desconcierto, y se reproducen al parecer sucesos olvidados cual si fuesen una verdad los círculos del Italiano Vico, y los enemigos implacables del progreso aprestan sus huestes, y se reniega del presente y se desconfía del porvenir.» ${ }^{31}$

Un jueves de agosto de 1886 abre portada de su número en Madrid el diario federal La República (1884-1891), órgano del partido republicano federal español de inspiración pimargaliana, donde analiza — probablemente de mano de su Director- ${ }^{32}$ la crónica política de la tarde a la vez que critica la sordera periodística de su rival La Correspondencia (1859-[1925]), y

28. $I b$.

29. M. Gil Maestre, «Conclusión», El Constitucional, Órgano del partido liberal dinástico de la Provincia de Gerona, a. VI, n. 798, Gerona, viernes 7 mayo 1886, p. 1 c. 4. Se trata de la última entrega del artículo que con ese título se inicia en el n. 796 el 2 de mayo.

30. $I b$.

31. $I b .$, p. 2 c. 1.

32. El abogado y político Pablo Correa y Zafrilla (1844-1888), «republicano federal de toda la vida», fue director del Diario Federal La República después de Telésforo Ojea y antes de Enrique Vera, y falleció de una «congestión cerebral» en la madrugada del 20 de abril de 1888 hallándose trabajando en la redacción del periódico, el mismo día en que venía de entrevistarse con su correligenionario Pi y Margall, jefe del Partido Federal. Véase la portada del número 1.319 de La República (año V) correspondiente al viernes 20 de abril de 1888, y el número 1.320 dedicado al día siguiente al Director finado. Cfr. M. OSSORIO y BERnard, Ensayo de un catálogo de periodistas españoles del siglo XIX, Imprenta y Litografia de José Palacios, Madrid, 1903 (1908), p. 92. 
enfoca su análisis en torno a la emergencia del general Martínez Campos como eje articulador y alma en la futura crisis otoñal de la política española. Todo ello a la vez que, repartiendo estopa al conservador Cánovas y al liberal Sagasta, la redacción federalista de La República desvela la política fusionista de los ya referidos turnos 'alternantes' de gobierno propios del diseño canovista:

«Decíamos que al general estaba reservada la gloria de suceder á Sagasta para dar paso á la izquierda que, seguramente, hubiéralo dado á su vez, como sucedió en otra ocasión, á los conservadores; como si todo el fin de esta política se redujese á demostrar prácticamente la teoría de Vico (no el actor ${ }^{33^{*}}$, sino el filósofo), reduciéndola á un círculo verdaderamente vicioso, que á tanto ha llegado el talento monstruoso de Cánovas, y no ha podido aprender más el mediocre talento de Sagasta.» ${ }^{34}$

Un año más tarde, en el antiliberal y reaccionario Diario Católico $E l$ Siglo Futuro (1875-1936), revuelto en sus páginas contra «la falsa interpretacion dada por los liberales y por los católicos-liberales, y áun tambien por otros pocos católicos» a la Alocución del 23 de mayo de 1887 del Papa León XIII (acerca de la renuncia de la Iglesia de Roma sobre su soberanía temporal), el sábado 20 de agosto de 1887 firma M.S.A. la sexta columna entrega del artículo «El poder temporal del Papa», en que discute la tesis acerca de la mayoría de edad y de la voluntad libre de un pueblo usada por «liberales y masones, lanzados contra su Dios, y su Cristo, y el Vicario de Cristo en la tierra», para ceder el poder temporal del Papa al Estado italiano. ${ }^{35}$ El autor ataca a los mantenedores del «falso principio» de la mayoría de edad de un

33. * Se refiere al famoso actor teatral Antonio Vico Pinto (1840-1902), natural de Jerez de la Frontera y fallecido en Cuba durante una gira teatral, miembro destacado de una saga familiar de actores.

34. [ ], «Madrid 18 de Agosto», La República. Diario Federal, a. III, n. 797, Madrid, 19 de agosto de 1886, p. 1 c. 1. «Martínez Campos piensa, según, que aquí no debe haber más jefe liberal que Sagasta, ni más presidente fusionista, dure lo que durare; pero que al término de este Gobierno, ya sea de un año, ya sea de un siglo, debe suceder Cánovas, que según un médico de baños asegura, vivirá mucho. En lo cual, así como en la conveniencia de que Cánovas suceda á Sagasta, el general cuenta con el decidido apoyo de los conservadores, que no es poco contar.» (Ib.).

35. M.S.A., «El poder temporal del Papa», VI, El Siglo Futuro. Diario Católico, a. XIII, n. 3.733, Madrid, 20 de agosto de 1887, p. 1, c. 1. Cfr. cita anterior en ib., c. 5, en la crónica «Carta de Roma». El periódico tuvo entre principales redactores y colaboradores a los tradicionalistas y apologetas católicos Gabino Tejado, Francisco Navarro Villoslada, Manuel Tamayo y Baus, Juan Manuel Ortí y Lara, 
pueblo, con capacidad plena, por tanto, para autogobernarse gracias a los progresos y «adelantos» de su edad. Dice así aliado del integrismo, en un texto que citaremos en extenso:

«Pero esto suponiendo con los progresistas que los pueblos siempre se encaminan á un bien mayor que el actualmente poseido, que les sirve de escalon para ulterior y máximo bien. ¿Pero esto es indudable? ¿No pueden tener razon los contrarios, los pesimistas que dicen ser ley de toda sociedad el decaimiento?

¿No puede tener razon Vico, que esplica los progresos de los pueblos recorriendo un círculo, en que el bien y el mal se suceden, alternan y como reentran uno en otro? ¡No puede tener razon Balbo, que prudentemente compara la vida del pueblo con la vida del hombre, y aquél como éste adelanta y retrasa, aprende y olvida, cae y se levanta, y redime más que por fuerza propia, por invisible y tutelar Providencia?

Propiamente hablando, los pueblos no tienen edades; tienen, sí, principio y fin, como todas las otras cosas del mundo; ique ni son expontáneos ni son eternos! Pero en ellos no pueden señalarse, como en los séres de vida fisica, por decirlo así, esos distintos y marcados é inalterables períodos en órden de sucesion, que se llaman infancia, virilidad y senectud. ¿Cuántos pueblos, robustísimos, prepotentes en su formacion, desaparecieron enfermizos ó sucumbieron débiles como el niño, bajo el poder, la tutela de otros pueblos? ¿Y cuántos otros débiles y atrasados nacieron para morir despues robustos, poderosos y llenos de sabiduría? ¿Tendremos necesidad de consultar la Historia? ¿No se recuerda la Roma pagana? ¿Nada se sabe de aquellos poderosos y florecientes imperios, allende los mares, que el valor de ínclitos españoles pusieron bajo la tutela de Cárlos I y sus sucesores[?].

¿Y cuándo tiene el pueblo voluntad para disponer de sí? ¿Cuándo puede escoger un pueblo libremente sus destinos? [...]; el pueblo no tiene poder, esto es, facultad legítima segun órden, para deponer á su arbitrio un rector y escoger otro, para cambiar una por otra la forma de su gobierno. Y esto, porque autoridad y gobierno, aunque nacidos de humanas condiciones, reciben de Dios autoridad [...].

\footnotetext{
José Fernández Montaña, etc. Las siglas del acrónimo M.S.A. muy probablemente pertenezcan a Manuel Sánchez Asensio (1860-1909), redactor desde 1886 y colaborador a diario durante este periodo ultracatólico y antiliberal del periódico madrileño, que más adelante en el siglo XX se volvería aún más fundamentalista. El periodista extremeño, más tarde miembro del partido integrista, fue fundador y director de varios efímeros proyectos periodísticos ultracatólicos, entre ellos El Observador de Cádiz en 1899. Volvió en sus útimos años a la redacción de El Siglo Futuro, donde trabajó hasta su muerte.
} 
Los pueblos, como los hombres, ni niños, ni adultos, ni ancianos, pueden obrar la iniquidad sin que Dios en lo eterno con su tremendo fallo, y la historia, con su juicio severo en lo temporal, exijan la debida reparacion, marcando el protervo para confusion suya, para enseñanza de las gentes, para satisfacción de la justicia.»>

Como se advierte, el redactor hace amplio uso, si bien crítico, de la tesis viquiana de la circularidad de la historia, del supuesto «pesimismo» histórico de Vico, aunque se admite como base de argumentación la doctrina providencialista del destino de los pueblos; pero no, en cambio, la doctrina evolutiva de las tres edades de las naciones, en cuyo último estado alcanzarían éstas con la humanidad plena la mejor forma de gobierno en el democrático, sea de la monarquía electa sea de la república popular.

A la contra del ideario reaccionario de El Siglo Futuro, vamos de vuelta nuevamente a las posiciones progresistas de Las Dominicales del Libre Pensamiento (1883-1909), que teniendo como redactores a sus cofundadores Ramón Chíes y «Demófilo», ${ }^{37}$ el sábado 10 de marzo de 1888, tras una primera página dedicada a la emancipación de los pueblos, en la segunda página vuelve a aparecer Vico relacionado con el nombre del herético Giordano Bruno y a propósito de «uno de los libros más singulares é interesantes del siglo XVI». ${ }^{38} \mathrm{Al}$ año siguiente, la página principal del mismo periódico librepensador trae a portada la tesis viquiana de la circularidad de la historia, criticada a propósito de una defensa del progreso total de la Humanidad. El filosófico artículo del escritor y periodista Eduardo Zamacois (1873-1971), reconocido ateo y anticlerical, no hace gala de apoyarse en doctrinas biológicas evolucionistas, como el darwinismo, sino que para defender la idea de un progreso no parcial sino pleno del género humano lo hace argumentando una completud que sobrepasa la idea de evolución de los organis-

36. M.S.A., «El poder temporal del Papa», VI, cit., p. 1 c. 2-4. «[...] todas estas nociones que después han dado origen al espíritu de la mitología, á la filosofía de las religiones y de la historia, á la ciencia de Vico y de Creuzer son para el Spaccio una vena inagotable de agudezas [...]» (ib., c. 3).

37. «Demófilo» era el pseudónimo masón utilizado por el militar republicano y periodista librepensador Fernando Lozano Montes (1844-1935); no debe confundirse con Antonio Machado Álvarez (18481893) que coetáneamente también usaba el mismo pseudónimo en Sevilla. Por su parte, el político y periodista Ramón Chíes (1846-1893) usó el pseudónimo de «Eduardo de Riofranco».

38. Ch. Bartholméss, «La expulsión de la Bestia triunfante. Obra de Giordano Bruno», I «Prólogo», Las Dominicales del Libre Pensamiento, a. VI, n. 279, Madrid, 10 de marzo de 1888, p. 2 c. 4. 
mos saltando a la evolución histórica cultural de las letras, la filosofía, las sociedades. Una columna y media resumen y concentran un repaso de doctrinas y perspectivas, desde la antigüedad hasta la modernidad, acerca del problema en torno al progreso universal, que hay que considerar «uno de los frutos del espiritu moderno». La defensa a ultranza que Zamacois realiza del sentido comunal del progreso histórico y de la implicación de los sistemas filosóficos (especialmente de la historia) en éste, se evidencia en algunas de sus rotundas afirmaciones, en las que se aprecia un acuerdo con la doctrina viquiana de la procesualidad de la historia de las naciones, aunque no con la asunción que Vico hace de la decadencia (descenso) como elemento tan determinante como el progreso (ascenso) en el proceso histórico de la humanidad. Ciertamente, Zamacois no alcanza a apreciar que esta doctrina viquiana de la historia, incompatible con el dogma de un progreso rectilíneo e indefinido, no significa circularidad repetitiva sino progreso en espiral, que de este modo hace que la humanidad vaya avanzando por fases de ascenso y descenso. El avance universal y pleno para Vico no es rectilíneo, como proponen los modernos defensores de la idea de progreso, sino curvilíneo. Mas esa originalidad de Vico queda oculta por la machacona presencia en las páginas de periódicos y revistas de la cansina metáfora de los «círculos de hierro», que Juan Donoso Cortés, Marqués de Valdegamas, llegó a exponer con gran entusiasmo y a popularizar con inusitada expansión. ${ }^{39}$ Zamacois, el novelista aliado del progresismo tanto como del republicanismo, afirma expresamente su creencia de que «Todos, absolutamente todos los hombres, ejercen una influencia más ó menos directa en el Progreso de los pueblos»; y que las ciencias «no progresan con independencia de las demás» sino «simultáneamente», hasta el punto de que llegan a darse «la mano las ciencias de observación y las filosóficas, antes tan divorciadas». Evidentemente, cree en el progreso de las «ciencias filosóficas»:

«ninguna revolución, por grande que pueda parecer, lleva inmediatamente la ruina total á un sistema: el vencido no se perderá, se amoldará solamente á las condiciones impuestas por el vencedor, podrá perderse en el tiempo totalmente, pero siempre vivirá en la historia»,

39. Vid. J. Donoso Cortés, «Filosofía de la Historia. Juan Bautista Vico. (Once artículos publicados en El Correo Nacional de Madrid en sept.-oct. de 1838)», ed. y nota por J.M. Sevilla, Cuadernos sobre Vico, n. 17/18, 2004-2005, pp. 489-526. Cfr. nuestro El espejo de la época..., cit., Parte II, cap. III «La modernidad de Vico como clave interpretativa del bifronte Donoso Cortés», en pp. 181-201. 
como «un paso más en la senda del progreso». ${ }^{40}$ Más aún, Zamacois deriva - sin mencionar a Vico - en tales viquianas consideraciones hacia la tesis de que «esto que sucede en filosofía, también acontece en las grandes revoluciones de los pueblos, como la historia nos enseña»; e incluso literalmente admite que la humanidad «desde los tiempos remotos» hasta nuestros días «no habrá caminado en línea recta, pero tampoco habrá retrocedido; ha marchado en zig-zag»..11 Nada más expresivo que esta consideración del avance zigzagueante para entender la propuesta de Vico (del movimiento serpenteante a semejanza del avance ondulatorio del ofidio sobre la duna de arena y no por analogía con la serpiente que se muerde la cola) que, sin embargo, Zamacois no advierte 'viquianamente' pues tiene a Vico como doctrinario del retroceso histórico. Lástima por la falta de conjunción, quizás debida a una falta real de lectura de la Ciencia nueva en vez de un conocimiento indirecto de interpretaciones a través de mediadores y de artículos de prensa. Así, y pese a todo, con gran intuición llega Zamacois a decir:

«No es la humanidad, como dice Vico, semejante á la bola de Sísifo, que cuando llega á cierto grado de esplendor, vuelve á sumergirse en los abismos de la ignorancia y de la barbarie para volver á empezar su trabajo de perfeccionamiento; antes al contrario, si vemos que una nación llega á la cúspide de su esplendor, y después decae y desaparece como la historia frecuentemente nos enseña, esta ruina no es total: acaba porque es preciso que ceda su puesto á otros pueblos que por sus condiciones especiales pueden llevar á cabo con mucha más facilidad la obra magna del progreso universal». ${ }^{\mathbf{2}}$

Recurrente siempre la referencia a los círculos de hierro, esta vez aparece la tópica metáfora de la mano de Pedro Sánchez en el diario cántabro El Atlántico (1886-1896), dirigido por Enrique Gutiérrez Cueto, prensa liberal dinástica e incluso posibilista, transeúnte por la senda abierta en los críticos tiempos anteriores por la gran cabecera — conservadora moderada-

40. E. Zamacois, «El progreso universal», Las Dominicales del Libre Pensamiento, a. VII, (¿n. 325?), Madrid, sábado 12 enero 1889, p. 1 cc. 3-4.

41. $I b$., c. 4 .

42. $I b$. 
La Abeja Montañesa (1857-1870). El autor recuerda experiencias norteafricanas de la civilidad e historia marroquí, ${ }^{43}$ en clave viquiana:

«Ya lo tenía bien sabido, y ello me satisfacía mucho, no saltábamos de la culta Europa á los pueblos orientales, medio amaestrados por la vieja civilización asiática en combinación con la nueva de aquella parte del mundo, sinó de ésta á la barbarie africana más ó menos lavada en la costa por el mar que la circunda. Iba á un pueblo, ejemplo mejor que ninguno del exagerado círculo de hierro de Vico, inmenso y prepotente de un día y hoy débil y envilecido, $[\ldots] . .{ }^{44}$

También hallamos citado a Vico en clave irónica y cómica, como así fuera hecho ya, por ejemplo, en 1858 por el «escritor humorista y agudo» Heliodoro del Busto ${ }^{45}$ cuando en el también conservador-moderado Diario de Córdoba (1849-1938) el escritor demócrata recogía con soberbia progresista decimonónica en Uno de tantos el nombre del napolitano junto al de otros filósofos modernos: «Bossuet, Vico, Kant y César Cantú no han hecho más que balbucear: nosotros hemos hablado». ${ }^{46} \mathrm{Se}$ lee treinta años después, en el semanario barcelonés — dirigido por J. Fernández de la Reguera y E. Belliure - La Semana Cómica (1887-¿1891/94?), en un diálogo escrito por su redactor José Borrás, la siguiente imaginaria conversación:

«-iBueno, bueno, don Genaro!

— ¡Vaya, vaya, don Andrés!

- Vengo asustado. - ¿Qué pasa?

-Nada; es que vengo de ver

á un genio, á un prodigio, á un hombre

43. El escrito se halla ubicado históricamente entre la ya sucedida Primera Guerra de Marruecos (la llamada "Guerra de África", 1859-1862) y la por llegar Primera Guerra del Rif (o "Guerra de Margallo”, 1893-1894) contra las cabilas que asediaban Melilla. Les habría de seguir, ya en el siglo nuevo, la Segunda Guerra hispano-marroquí (o “Guerra del Rif”, 1911-1926).

44. P. Sánchez, «Recuerdos de Tánger. Apuntes de cinco días». I. «De España á Africa», El Atlántico, a. III, n. 122, Madrid, viernes 4 mayo 1888, pp. 1-2; cit. p. 2 c. 1. «Pedro Sánchez» era el pseudónimo del escritor santanderino José María Quintanilla (1867-1925), uno de los fundadores de la Sociedad Menéndez Pelayo. Recuerdos de Tánger fue su único libro que dejó, junto a multitud de artículos.

45. Cfr. Rodolfo GiL, Córdoba Contemporánea, Impr. y Papelería Catalana, Córdoba, 1982, t. 1 (18591891), p. 100.

46. Diario de Córdoba, a. IX, n. 2.349, 17 de octubre de 1858; folletín p. 2 c. 4. Cfr. nuestra citada Adenda III: «Ráfagas de Vico en la prensa diaria ...», en la revista italiana Rocinante. 
atroz. Figúrese usted

que se sabe de memoria

todo lo que hay que saber;

las obras de los filósofos

no son nada para él,

y le dice á usté enseguida

lo mismo que el A, B, C,

quienes fueron Epicuro,

Spencer, Balmes, Janer,

Platon, Epitecto, Kant,

Diderot, Scheling [sic], Bossuet,

Maquiavelo, Condillac,

Descartes, Kempis, Voltaire,

Pascal, Bentham, Sainz del Rio,

Stuart Mil y Lamennais.

¿Y de escritos? ¡No digamos!

El conoce los de Behr,

Salmeron, San Agustin,

Schopenhauer, Lerminier,

Büchuer, Gonzalez Serrano,

Maimónides, D' Alembert,

Ahrens, Stahl, Taparelli,

Montesquiu [sic], Proudhon, Litré,

Hegel, Hobles [sic], Zoroastro,

Azcárate, Wolff, Cousin,

Séneca, Gall, Aristóteles,

Fichte, Fenelon, Giner,

Roeder, Hartmann, Compte, Vico,

Malebranche y Tiberghien.

¿Y de Teólogos?......—¡Basta!

Basta, por Dios, Don Andrés!

¿Y dónde está ese prodigio?

- ¿Que no lo adivina usted?

- No por cierto.-Pues es fácil.

-No caigo.-Piénselo bíen.

_ ¿En la Academia Española?

—iQuiá! No señor.-iEn la de.....

la Historia?-Tampoco._¿En la......

de Ciencias?-Menos._¿En el...... 
Ateneo?-Ni por pienso.

— ¿Tampoco? ¡Pues no lo sé!

-Pues hombre.. ¿dónde ha de estar?

Ya se sabe... ¡¡En Leganés!!» ${ }^{47}$

Hemos querido citar por extenso con objeto de mostrar cómo el nombre Vico aparece acogido en el seno de la lista de filósofos considerados más eminentes e influyentes en el siglo XIX español. Y como indica el final, se advierte que está presente este conocimiento en la calle, ${ }^{48}$ siempre gracias a la prensa, y no sólo en las Academias ni Ateneos. Lo mismo que con comicidad y cierta sorna se constata en la breve ficción literaria del polígrafo salmantino y filokrausista Fernando Araujo Gómez (1857-1915), donde imaginariamente acontece que, a propósito de las fechas de exámenes, un estudiante dice a otro:

$\ll[\ldots]$

-Dispénsame que te interrumpa; tu estás enterado y vengo á pedirte un favor. ¿Me podrias decir algo de los sistemas de Filosofía de la Historia?

- ¿Es broma?

- Hombre, no; me veo en un compromiso; tengo una lección en el programa que trata de eso y no sé ni chispa. [...]

— ¿Lo sabías? Aguárdate un poco. Pues bien, ya sabes que san Agustín fue un santo... - ¿Vaya noticia!

- ¿Lo sabías? Pues ya sabes tanto como yo; porque es lo único que sé de sistemas de Filosofía de la Historia; Bossuet, Vico, Herder, Hegel, Schlegel, Krause y demás compañeros mártires los conozco de nombre; pero ni sé si fueron ministros de Hacienda ó escribientes de algún Gobierno civil, y en cuanto á sus sistemas nunca me he metido á averiguarlos.

—Me has fastidiado!» ${ }^{49}$

47. José Borrás, «Pues claro!», La Semana Cómica, a. II, n. 47, Barcelona, 20 de abril de 1888, p. 3 c. 1. 48. Leganés, barrio castizo y popular de Madrid.

49. F. Araujo, «Los exámenes. (Cuadros al vivo)», La Ilustración Artística, a. VII, n. 339, Barcelona, 25 de junio de 1888, pp. 2-3 (en el ejemplar: pp. 215-216; cita en p. 216 c. 1). Este diálogo satírico de Araujo ya había sido publicado antes en el periódico constitucional La Mañana, a. IV, n. 1.021, León, 7 de junio de 1879, p. 1 c. 4 (cfr. nuestra ya citada Adenda IV en Bollettino della Società Filosofica Italiana, pp. 38-39); y años después aparecerá también en el periódico político bisemanal, dirigido por el propio Araujo, El Progreso, a. I, n. 14, Salamanca, 8 de junio de 1884, p. 1 c. 2. Lo cual denota que en décadas parece que no perdiera actualidad. 
Hasta el mismísimo conocido escritor y crítico literario Leopoldo Alas «Clarín» (1852-1901), en plena reflexión y comentario sobre el romanticismo, pues «han hablado algunos gacetilleros, muy metidos en harina estética, de si convenía ó no restaurar el romanticismo» — y vale más que no, según Clarín, y no tanto por ello mismo «sino por los disparates que habían de llamar romanticismo»-, dice en uno de sus cínicos y críticos apartes en el Madrid Cómico (1890-1923) —dirigido por Sinerio Delgado-:

«En estos asuntos de literatura española yo soy partidario de la teoría de Vico, no el cómico, sino el otro (el otro Mercier, como dice Cánovas),* Vico el de la Scienza nuova. Sí, creo en los cielos, en la vuelta de los Herranz, Retes, Castro, Díaz, Larra y otros aparecidos.» ${ }^{\mathbf{5 0}}$

Equívoco entre el filósofo napolitano y el conocido actor teatral con el que también juega más tarde el escritor y periodista aragonés Luis Royo Villanova (1867-1900) en el jaranero e ilustrado periódico La Semana Cómica - que ya hemos referido- denunciando grandes confusiones, tanto de gente común como de notables pantólogos ${ }^{51}$ opinadores de todo y sabedores de poco o nada, que pululan por doquier. Así, por ejemplo, redacta con ironía el «escritor festivo» un agudo aguijonazo a los enterados de Salón:

«[...] —En España, - se decía en una ocasión,- - hay familias privilegiadas. Ahí tiene usted los Silvela, los Madrazo, los Benlliure...

-Y los Cano,- - añadió un circunstante.

- Hombre, no: fuera de D. Leopoldo...

- ¿Y Melchor Cano y Alonso Cano, no son nadie?

Hay dinástico que perdona á Zorrilla todos sus manejos revolucionarios por el Tenorio y Margarita la Tornera; abonado al Español que felicita á Vico por su Scienza nuova, y católico escrupuloso que se resiste á leer el "Tratado de lo sublime" por Longino, acordándose de aquella lanzada de la Pasión».52

50. Clarín, «Palique», Madrid Cómico. Periódico semanal, a. 10, n. 363, Madrid, 1 de febrero de 1890, p. 3, citas c. 2. *Véanse notas 33 y 34 supra.

51. Tomo la expresión prestada de José Villalobos, Elogio de la radicalidad, Secretariado de Publicaciones (Universidad de Sevilla), Sevilla, 2004 ( $2^{\mathrm{a}}$ ed. rev. y amp.), Ap. 2: Fascinatio nugacitatis, p. 126. ID., «Vico, ensayador», Cuadernos sobre Vico, 30/31, 2016-2017, pp. 473-480; cfr. pp. 473-475.

52. L. Royo Villanova, «Confusiones», La semana Cómica, a. V, n. 41 , Barcelona, 5 de noviembre de 1891, pp. $3^{\text {a }}-4^{\text {a }}$ (pp. 387-388), cit. p. 387. El periodista zaragozano colaboró también con el semanario satírico Gedeón y con La Ilustración Española, fue redactor de El Nacional y más tarde de Blanco y Negro (cfr. Manuel Ossorio y Bernal, Ensayo de un catálogo de Periodistas Españoles del siglo XIX, Imprenta y Litografía de J. Palacios, Madrid, 1903, entrada en p. 396). 
Y con igual sentido entre comedia e ironía, que denuncia el fácil error con que Vico podría - por su importancia en el discurso literario o académico no menos que en el artículo de prensa - ser citado más por ignorancia que por conocimiento, confundido incluso con el famoso actor teatral, es por lo que, en un discurso crítico con la política gubernamental, a modo de editorial leemos en la primera del Diario Federal La República (1884-1891):

«Llega el otoño, y vuelta á empezar. La historia de nuestra política, contrariando las leyes de la historia humana, se repite siempre. Vico, no el actor, (no vaya á confundirlo el duque de Tetuán o Martínez Campos) presintió á los políticos españoles cuando afirmó las bases de su sistema filosófico.

En el círculo vicioso que exponemos se desenvuelve constantemente la política española, que considerada en su aspecto fundamental responde perfectamente á su historia. $[\ldots]\rangle .^{\mathbf{5 3}}$

Recurso éste utilizado también por el palafrugellence Pedro Bofill (1840-1894) en su repaso al libro de Ricardo Sepúlveda El corral de la Pacheca (apuntes para la historia del teatro español), cuando en el artículo que el crítico teatral publica a mediados de junio de 1893 en La Época (18491936) se finaliza diciendo:

«Pero repito lo que dije al principio: Nihil novum sub sole. Lo que ocurrió ayer, pasa hoy, y sucederá mañana, mientras la humanidad no cambie de condición, lo cual lo considero muy difícil.

La Zarabanda y la Danse du ventre, se dan la mano al través de los siglos.

Vico tenía razón... (no el actor español, sino el filósofo italiano), cuando decía en su Scienza nuova que los hechos se repetían á grandes intervalos al través de la Historia.

Es la simbólica serpiente que se muerde la cola. En la cabeza está la Mariflores, y la Bella Chiquita constituye el rabo.» ${ }^{\mathbf{5 4}}$

53. [ ], «Política de verano», La república. Diario Federal. Iniciador y Órgano de la Coalición Republicana, a. VIII, n. 2.328, Madrid, miércoles 22 julio 1891, p. 1 c. 1. Periódico creado y sostenido por el aristócrata revolucionario Enrique Pérez Guzmán, finalizó su actividad el 28 de noviembre de 1891 debido a los desacuerdos de estrategia política periodística entre el Marqués republicano y Pi y Margall.

54. P. BofiLl, «La Mariflores y la Bella Chiquita», La Época. Últimas noticias y telegramas de la tarde, a. XLV, n. 14.639, Madrid, sábado 17 de junio de 1893, p. 1 cc. 4-5; cit. c. 5. «Pere Bofill (Palafrugell, 1840 - Madrid, 1894) fue bibliotecario del Cuerpo de Telégrafos en Madrid. Colaboró en El Globo, El Progreso, El Pueblo y La Época, donde desarrolló el cargo de responsable de la sección literaria y teatral. 
Comicidad y juego de equívocos que llegan hasta 1900 en las páginas del semanario satírico madrileño Gedeón subtitulado «Ex-Diputado á Cortes por Madrid»(1895-1912), periódico conservador (siempre con el Partido Liberal de Sagasta en el punto de mira) que incluye entre los versos de una humorística «Elegía» dedicada al recién cesado ministro de Hacienda, el conservador Fernández Villaverde, tras haber accedido a la presidencia el también conservador Silvela (a quien, paradójicamente, en julio de 1903 sucederá Villaverde de presidente tras la dimisión de Silvela):

«Ya no es nadie! ... Perdida su arrogancia, perdió también sus clásicos encantos, no es el hombre feliz en su importancia ¡hoy es uno de tantos!

Sin uso de galones, Ya no recibe cartas ni secretos, ¡tendrá que pasearse en los simones por el Prado, el Retiro y Recoletos!

Con sombrero de paja,

Y muy modestamente

Se le ve por la calle... ¿Estando en baja

Ya no le admira la perdutta gente!

¡Ley de la historia! Eternas vanidades

que ya explicaba el tratadista Vico.

(No confundirle con el grande en chico

que asombraba hace poco en Novedades)..> ${ }^{55}$

Mas la ironía, la comedia y la sátira, incluso — como en el último caso - el cinismo, no hacen sino evidenciar el anuncio de la gran crisis de fin de siglo. «Atravesamos una crisis histórica; leyes, instituciones y doctrinas comparecen ante el tribunal de la razón», dice Víctor Oscáriz y Lasaga (1831¿?) en un denso Discurso depuesto en el Congreso Espiritista de Barcelona en 1888. En él, el conocido y brillante expositor de la doctrina espirita esgrime

Fue también adaptador de teatro francés» (JOAN MARTORÍ, La projecció d’Àngel Guimerà a Madrid (18911924), Curial Edicions Catalanes, Barcelona, 1995, p. 29, nota 49 [en catalán]; y cfr. Anales galdosianos, v. 17-18, 1982, p. 38, n. 6).

55. [ ], «Elegía á las ruinas de Villaverde», Gedeón (Ex-Diputado á Cortes por Madrid), a. VI, n. 242, Madrid, 11 de julio de 1900, p. 2 c. 3 y p. 3 c. 1 (citación). El semanario incluía en su cabecera la leyenda «GEDEÓn es el periódico de menos circulación de España». 
que «Si es admirable la Exposición de Barcelona, no lo es menos la exposición universal de todos los sistemas filosóficos que se agitan en estos Congresos para dar una solución al problema del porvenir». Y así, al dar la bienvenida a la delegación italiana al Congreso, loando las excelencias filosóficas del país vecino llega a decir Oscáriz, según se lee en el Periódico Federal madrileño que publica su disertación, que «cuando se visitan sus bibliotecas, salen al encuentro Vico, Filangieri, Volta y Galliani». ${ }^{\mathbf{5 6}}$ Mas no se tenga esta descripción como una mera figura retórica por parte del profesor, pues Oscáriz ha reconocido en Vico desde años atrás al filósofo moderno iniciador de la Filosofía de la Historia. ${ }^{57}$ Uno de aquellos filósofos modernos que nos salen al encuentro a luchar junto a nosotros ante nuestros propios problemas (que es lo que, dicho sea de paso, orteguianamente define a un clásico).

Sí que, en cambio, gusta dar razón a «la quisicosa de la rueda de Vico» el poeta y literato Ramón de Campoamor (1817-1901), a quien ya nos hemos referido en anteriores sedes, ${ }^{\mathbf{5 8}}$ mas en esta ocasión lo recordamos porque - a cuenta de la historia de las ideas de Marcelino Menéndez Pelayo (1856-1912) — el académico de la historia, filósofo ideísta e ideólogo conservador repasa someramente una línea de historia de la filosofía de la historia para mostrar que las ideas operan en la historia tanto por ausencia como lo hacen por presencia, de modo que no existe ninguna presunta ley histórica que fuese tan universal como para comprender la «lucha eterna» entre el espíritu y el cuerpo, entre la idea y la materia. Así lo leemos en la primera entrega para el semanario badajoceño La Idea (1889-?) del artículo que, con el título «De la marcha de las ideas en la Historia», ${ }^{\mathbf{5 9}}$ sin embargo no es más

56. V. OscárIz, «Discurso», Las Regiones. Periódico Federal, a. II, n. 59, Madrid, 10 de noviembre de 1888, p. 3 c. 2. El catedrático de Retórica y Poética en el Instituto de Santander y, desde 1879, en el de Teruel, había escrito y publicado años antes, en 1875, un mamotreto titulado Universo espiritista. Con frecuencia, en el siglo XIX español, la doctrina espiritista estuvo vinculada al movimiento activista del liberalismo frente al absolutismo monárquico o católico, y tuvo gran despliegue entre intelectuales y políticos en esta época finisecular.

57. Cfr. nuestra Adenda IV citada, pp. 27, 28 y 38.

58. Véase El Espejo de la época, cit., pp. 104-106.

59. R. DE CAMPOAMOR, «De la marcha de las ideas en la historia», La Idea. Órgano de la Enseñanza, a. II, n. 25, Badajoz, 26 de marzo de 1890, pp. 2-3 (numeradas son pp. 74-75). Sobre Vico: en la segunda página, p. 74 c. 1 («Vico reduce la vida de los pueblos á tres edades, de crecimiento, virilidad y decrepitud, haciéndoles girar dentro de ellas perpétua y fatalmente.»); c. 2 (refiriéndose a la concepción cristiana de Bossuet: «Nuevo fatalismo, no menos ineludible que el destino pagano, ni menos inque- 


\section{que un capítulo extraído de su obra El Ideísmo (1883). ${ }^{60}$}

«Pero ¿puede haber una ley de la historia? ¡No.! Ni la rueda de Vico, más vertiginosa que la de un molino; ni la Providencia, obrando á gusto de Bossuet en un rinconcito de la tierra; ni los canjilones de noria de la idea hegeliana, ni el gas poético con que el Sr. Menendez Pelayo infla los hechos, son sistemas ideológicos que puedan abarcar la universidad de la vida y constituir lo que se llama ciencia.» ${ }^{\mathbf{6 1}}$

Por el mismo año, mediando el mes de julio, el periódico semanal anticlerical y republicanista El Motín (1881-1926), fundado y dirigido por el conocido periodista republicano José Nakens (1841-1926), publica la tercera de las Cartas al Obispo redactada por la pluma del escritor y periodista Luis París (1863-1936), uno de los miembros del activista grupo «Gente Nueva». ${ }^{62}$ París arremete contra quienes, como el obispo, cuestionan que Giordano Bruno fuera quemado vivo en la romana Plaza de las Flores, y por el contrario lo eleva a «mártir de la intolerancia católica». En su apología de la cientificidad de Bruno, París lo relaciona entre otros autores con Vico:

«Vamos á insistir acerca de Bruno, filósofo; [...]. Bruno se guió en todas sus enseñanzas, sus juicios y sus libros por el criterio experimental, sancionado hoy por la ciencia moderna, que aplicó así á la exposición del método analítico como al examen de las doctrinas de la evolución de la materia y de su unidad orgánica. Compañero en sus adivinaciones de Kepler, Ticho Brahe y Copérnico, exploradores del

brantable que el circulo de hierro de Vico»; y también la cita infra); y en la tercera, p. 75 c. 1 (al hablar del movimiento que va del despotismo a la anarquía para comenzar de nuevo por el absolutismo: «y así incesantemente, hasta dar una sobra de razon á la quisicosa de la rueda de Vico, que, en momentos dados y en puntos reducidos, parece que efectivamente los acontecimientos políticos obedecen á una ley histórica fatal.»).

60. R. DE CAmPOAMOR, El ideísmo (1883), cap. VII «De la marcha de las ideas en la historia», apdo. II «Leyes históricas de Vico, Bossuet, Montesquieu y Hegel». En Obras completas de R. DE CAMPOAMOR (Madrid, 1901-1903) a cargo de Urbano González Serrano, Vicente Colorado y Mariano Ordóñez. Cfr. El espejo de la epoca, cit., p. 104, n. 73.

61. R. DE GAMPOAMOR, «De la marcha de las ideas en la historia», La Idea, cit., p. 74 c. 1.

62. Un «grupo rebelde» - tanto en política como en generación literaria - en el que estaban integrados, además de París y del propio Nakens, también Alejandro Sawa, Ricardo Fuente, Manuel Paso, Joaquín Dicenta, Luis Bonafoux, entre otros (cfr. José Luis Cano, Historia y poesía, Anthropos, Barcelona, 1992, p. 90). Luis París fue también empresario teatral y director del Teatro Real de Madrid, además de autor de la obra en 1889 Gente nueva. Crítica inductiva (hay una reciente edición a cargo de Jesús Rubio Jiménez en Athenaica Ediciones, 2017). Entre algunos de los principales literatos de la época durante la Restauración se relacionó con Clarín y coincidió con Azorín en algunos periódicos. 
infinito, fué predecesor de Bacon y anuncio de Descartes. Kant y Schelling han sancionado su metafísica, con las doctrinas de la razón teórica y la razón práctica; desde Leibnitz, Newton, Clarke, Vico y Spinosa hasta Hegel, toda la filosofía moderna ha seguido el plan que trazaran Bruno y su antecesor Raimundo Lulio, y enfrente de la opinión de unos cuantos clérigos fanáticos é iletrados se levanta el grito de admiración de filósofos italianos tan ilustres como Campanella Tomaso [sic], Mazuchelli, Tiraboschi, Sarpi, Rosmini, Mamiani y Levi, y extranjeros tan eminentes como Bruker Rixner, Cousin, Frank, Littré, "Nicerón, Clemens, y otros cien que aclaman, comparten y propagan el espíritu del renacimiento filosófico que tan gloriosamente inició Bruno.» ${ }^{63}$

Algunas breves citas y referencias más aparecen durante ese mismo año inicial de 1890 en noticiarios generales, ${ }^{64}$ por ejemplo el 14 de abril en El Ripollés (1888-1889), semanario surgido de la fusión de El Taga y El Jueves. ${ }^{65}$ En un artículo en castellano copando toda la segunda página a tres columnas, José de Capdevila arremete contra el sofisma imperante que ve en la sociedad narcotizada por «la charla de un sicofanta, largo en discursos y en razones breve, que al calor de mal planteadas hipótesis y peor demostrados teoremas prétenda esclavizar á su capricho las masas». Y así escribe el ínclito redactor:

«La sofisticacion ha enarbolado su bandera en mengua de la verdadera filosofía, y sus satélites, no pudiendo albergarse en el seno de la ciencia, sentaron sus reales entre las espesas nubes de la ignorancia á fin de con adulteradas hipótesis producir la descentralización de la sociedad encenegándola en la molicie y hediondez hasta descender á la crápula venal.

\footnotetext{
* Algunos años más adelante puede encontrarse una cita de Littré sobre Vico en la cuarta entrega para el folletín de La Autonomía: véase «Las evoluciones de la Historia. Por E. Littré. (Traducido exprofeso para La Autonomía)» (4), La Autonomía. Diario Republicano, Defensor del Partido Único, a. IV, n. 902, Reus, sábado 20 noviembre 1897, p. 2. «Finalmente, no es verdad que la evolución sea circular como había imaginado Vico. El círculo es excluido por el progreso científico, que está necesariamente en una dirección rectilínea» (ib., c. 3).

63. Luis París, «Cartas al Obispo», III, El Motín. Periódico Satírico Semanal, a. X, n. 27, Madrid, 10 julio 1890, pp. 1-2; cita p. 2 c. 1.

64. Como en El Eco de Valls. Periódico político de avisos y noticias, Órgano del Partido Liberal del distrito de Valls-Montblanch, a. VII, n. 51, Valls, Domingo 23 de junio de 1889, p. $1^{\text {a }}$ (en fascículo p. 17, acerca de la idea de Vico sobre el primigenio gobierno de Roma).

65. Joan Givanel i Mas (Comp.), Bibliografia catalana. Premsa, Instituciò Patxot, Barcelona, 1937, vol. II, p. 355.
} 
El sofisma reduce al sér humano á un autómata dentro del mecanismo social y considera á los pueblos como meras formas del espíritu mundano sin personal entidad ni derecho. Tal es la brevísima tésis de la teoría de Hegel. Y no se crea que tamaños males hayan nacido entre nosotros, pues Juan Bautista Vico sostiene que todas las naciones por distintas que sean y lejanas que estén, corren idénticas vicisitudes, como nos lo prueba Grecia en tiempos posteriores á Esquilo..» ${ }^{66}$

En la misma órbita ideológica católica hallamos el diario liberal-progresista mallorquín El Isleño (1857-1898 [con interrupciones]), en su número dedicado a continuar relatando el Congreso Católico celebrado en Madrid, centrado en su octava sesión en el celebrado discurso del apologeta Alejandro Pidal y Mon (1846-1913), del cual destaca y cita el redactor, a propósito del problema de la existencia de Dios el siguiente argumento ontoteológico:

«La existencia de Dios no se puede demostrar por argumentos a prio$r i$, que merecen la acusación de impiedad, porque justamente los anatemizaba Vico, en razòn à que estos argumentos le negarían en vez de demostrarlo, toda vez que intentar demostrar à priori á Dios equivale á asignar una causa à lo que precisamente se llama Dios por ser causa de todas las causes [sic] del Universo.» ${ }^{67}$

Argumento de Pidal y Mon que se refiere, sin hacerse constar, al De Antiquissima, donde Vico expresa este razonamiento a propósito del criterio verum-factum (pues ya Vico había resuelto en 1710, de conformidad con el principio verum ipsum factum, que centra toda su doctrina metafísica y epistemológica, que intentar demostrar a Dios mediante argumentos ontológicos sería tanto como pretender haberlo hecho, pues sólo por su causa demuestra el autor); y tesis que esgrime Pidal y Mon frente a los argumentos ontológicos y racionalistas de Kant, Jacobi o Lamennais y a favor de las vías demostrativas de Tomás de Aquino.

66. J. de CAPdevila, «El sofisma en este siglo», El Ripollés. Semanario de avisos y noticias. Defensor de los intereses del país, 1, n. 60, Ripoll, domingo 14 abril 1889, p. 2 c. 2.

67. [], «Congreso Católico», El Isleño. Periódico de intereses materiales, a. XXIII, n. 10.671, Palma de Mallorca, jueves 9 de mayo de 1889. Resumen del Discurso de Pidal y Mon en p. 2 cc. 2-4; citado c. 2 [ref. a Vico] y c. 3 . 
Entre otros periódicos que reseñan por entregas las actividades del Congreso Católico español se encuentra también el semanario El Orden, que en su número de 12 de mayo de 1889 precisamente interrumpe los relatos sobre el Congreso, pero en cambio publica el Discurso de Pidal y Mon a tres páginas completas, anunciando al final su continuación. ${ }^{68}$ Discurso publicado también por La Unión Católica, Diario Religioso, Político y Literario (1887-1899), que en el mes de agosto vuelve a poner el nombre de Vico en portada como colofón del artículo del tradicionalista cacereño Eugenio Fernández Hidalgo acerca de San Agustín, una loada y empalagosa admiración por «su vastísima construccion de la filosofía de la historia, que inspiró al gran Bossuet, y cuyo influjo se ha dejado sentir hasta en los sistemas deterministas ó racionalistas de Vico, Hegel, Condorcet, Herder, Krausse [sic], y en el sistema cristiano de Scheleyer [sic] sobre todo.» ${ }^{69}$

\section{El decenio de camino al '98. La doctrina de Vico «puede aplicarse á nuestra patria».}

La década de los años '90 en el siglo XIX mantiene esa misma tensión beligerante, ejemplarizada en la prensa periódica, entre conservadores y progresistas, entre liberales y tradicionalistas, entre católicos y laicos independientes, entre monárquicos y republicanos, cualesquiera que fuesen sus combinaciones de pares y sus alianzas.

Además de las iniciales recepciones viquianas en 1890, ya referidas más arriba, 1891 acoge algunas también significativas, como la del noticiario insular Diario de Tenerife (1886-¿1887?), que señala entre las efemérides aquélla de la muerte de Vico, «filósofo italiano», tal día como la fecha del periódico de 20 de enero, con noticia en portada de que en Toulouse ha descendido la temperatura a veinte grados centígrados bajo cero, y con el recordatorio de que justo un año antes había fallecido quien fuera rey de España,

68. «Discurso pronunciado en la sesión última del Congreso católico por el Excmo. Sr. Don Alejandro Pidal y Mon», El Orden, a. III, n. 19, Tortosa, 12 de mayo de 1889, pp. 2-4. Cita a Vico en p. 2 c. 4.

69. E. Fernández HidAlgo, «El águila de Hipona», La Unión Católica, a. III. N. 672, Madrid, miércoles 28 de agosto de 1889, p. 1 c. 2. Véase un criterio similar del mismo autor expresado años atrás en La Unión, el viernes santo 3 de abril de 1885. Vid. nota 14 supra. 
Amadeo de Saboya. ${ }^{70}$ Meses después el mismo periódico canario recoge un artículo del periodista y conocido político liberal Julio Burell (1859-1919), aparecido dos semanas antes en La Lucha (1871-), Órgano del Partido Liberal de la Provincia de Gerona. En el artículo Burell analiza la política francesa desde el prisma de la pequeña historia en torno al suicidio del general Boulanger tras su hundimiento por el amor de la pálida Mme. Bonnemain. El Boulanger que rompe la espada del poder antes de ser vencido por Constans, al igual que Marco Antonio con Octavio impulsado por la atracción hacia la reina egipcia. Césares sin llegar a emperadores debido a la subyugación frente al amor y las noches de alcoba. Para el autor, que se desliza entre teoría política y misoginia: «La política es fuerza; y el amor, cuando no es desmayo, es algo que pone plomo en los piés y ligaduras en las manos». Al «hombre de Estado, [...], nunca le servirá de aliento el suspiro cercano de una mujer». ${ }^{71}$ Consideraciones más mundanas que históricas, para las que Burrell busca un gratuito ataque a la filosofía moderna, en pro de la doctrina cíclica de Vico:

«Y he aquí à la filosofía cruzándose de brazos y al naturalismo en el arte con sus fórmulas destrozadas. A los diecinueve siglos Marco Antonio es continuado por Boulanger... ¿Qué dice á esto la filosofía moderna, que se ríe de los círculos concéntricos de Vico? ¿Qué dicen

70. [Efemérides], Diario de Tenerife. Periódico de intereses generales, noticias y anuncios, a. V, n. 1.265, Santa Cruz de Tenerife, martes 20 de enero de 1891, p. 1 c. 2. La creencia común es que Vico falleció en ese día 20 de enero, según relato del marqués de Villarosa (Gli ultimi anni del Vico; en la edición de Mario Fubini de: G. VICO, Autobiografia seguita da una scelta di lettere, oriazioni e rime, Einaudi, Turín, 1960: «tranquillamente spirò nel dì 20 gennaio 1744, avendo l'anno settantasei di età sua trapassato»). Benedetto Croce corrigió las fechas de nacimiento y de fallecimiento: 23 de junio de 1668 la primera (y no de 1670 que dice Vico en su Vita) y 23 de enero de 1744 la segunda (y no el 20 de enero, como decían los biógrafos). B. Croce, «Intorno alla vita e al carattere di G.B. Vico» (conferencia impartida en la Società Napoletana di Storia Patria el 14 de abril de 1909), recogida como apéndide I en su obra La filosofia di G.B. Vico (1911), sexta edición en Laterza, Bari, 1962 (4a ed. económica en marzo 1980, la aquí citada: pp. 253-280, ref. en nota a pie de página 253). Cfr. el Vico de EnRICo Nuzzo (Valecchi ed., Florencia, 1974, p. 36): «Questa [la muerte] sopravvenne tra il 22 e il 23 gennaio de 1744». La «ceremonia de su sepultura, con honores universitarios y con un día de retraso, se celebró el 24 de enero de 1744», pocos meses antes de que saliera de imprenta la tercera, última y —obligadamentedefinitiva edición de la Scienza nuova (M. GonzÁlez García y J. Martínez Bisbal, «La autobiografía de G. Vico. Claves para una lectura», en la edición a cargo de ambos de la Autobiografia de Giambattista Vico, Siglo Veintiuno de España Editores, Madrid, 1998, p. 51). Al año siguiente, en el número 1.563 de miércoles 20 enero 1892, el mismo diario tinerfeño reproduce en su primera página la misma esquela de Efemérides. También en el n. 1.861 del a. VII en 1893; en el n. 2.157 del a. VIII en 1894; y así, más actualizada y extensa la lista, en el n. 2.753 del a. X en 1896.

71. J. BuRELL, «La política y el amor», La Lucha. Diario político, de avisos, noticias é intereses generales, a. XXI, n. 4.503, Gerona, miércoles 7 de octubre de 1891, pp. 1-2; cita p. 2 c. 3. J. BureLL, «La política y el amor», Diario de Tenerife. Periódico de intereses generales, noticias y anuncios, a. V, n. 1.488, Santa 
á esto los naturalistas, que combinan los caracteres como las sustancias minerales? ${ }^{72}$

En el periódico canovista La Libertad (1890-1892), dirigido por Javier Betegón, ${ }^{73}$ se halla un interesante relato sobre Edgard Quinet (1803-1875), el joven traductor francés de la Introducción a la filosofía de la historia de Herder, firmado en la columna «Palabras y Plumas» por las iniciales de "M. de C.”. Viene a propósito de la denuncia acerca de la presunta acción explotadora en beneficio de su producción que llevaría a cabo el ecléctico Victor Cousin con sus jóvenes discípulos, en que el anónimo bajo acrónimo autor cita a Vico al reproducir un texto del propio Quinet refiriéndose éste a sí mismo $-\mathrm{y}$ su proyecto sobre Herder - y a su colega Michelet — y su proyecto sobre Vicoen un encuentro con el viejo Cousin. Dice Quinet, según recoge "M. de C.”:

«Una de las cosas que me sorprendieron extraordinariamente, se refieren á mis primeras entrevistas con Michelet, M. Cousin nos llenaba de cumplimentos y de elogios á entrambos, preguntándonos por nuestros trabajos y por nuestros proyectos. Expuesto nuestro plan para el porvenir, y los dos en el camino de la filosofía de la Historia, Michelet con Vico, y yo con Herder, M. de Cousin nos pronunció un magnífico discurso, y con su acostumbrada solemnidad, tomando un aire grave, nos habló de la santidad del sacrificio, de la necesidad de inmolar nuestros gustos, nuestras aspiraciones, el porvenir á que nos creíamos llamados. Según M. Cousin, nuestro deber nos imponía trabajos obscuros, dificultosos, fastidiosos, á los cuales habíamos de entregarnos dedicándoles diez años de nuestra juventud.

Exaltándose con sus propias palabras y cogiéndonos las manos, exclamó: "Sí, jóvenes amigos míos, no veo porvenir más hermoso que aquel cuyo plan voy yo mismo á trazar. Quinet emprenderá, durante

Cruz de Tenerife, 20 de octubre de 1891, p. 3 cc. 2-3; citas c. 3. [La firma aparece "Burell" en La Lucha y "Burrell" en el Diario de Tenerife]. Debe de tratarse del cordobés Julio Burel y Cuéllar, apreciado periodista relacionado con la Generación del '98 y reconocido político que, en tiempos de crisis, además de gobernador civil con Alfonso XIII, entre 1910 y 1918, tuvo carteras ministeriales con Canalejas, Romanones y García Prieto. Ejerciendo de ministro de Instrucción Pública y Bellas Artes otorgó una cátedra a Emilia Pardo Bazán y decretó el acceso de la mujer a la Universidad y a la función pública ministerial. Valle-Inclán lo representa como el ministro de Gobernación Don Paco en Luces de Bohemia.

72. Ib., La Lucha, p. 2 c. 2; Ib., Diario de Tenerife, p. 3 c. 2.

73. Francisco Javier Betegón (1857-1919) fue un director liberal-conservador y monárquico, influyente durante la restauración canovista y secretario general de la Asociación de la Prensa de Madrid (APM) entre 1897 y 1909. Betegón dirigió La Unión (1887), La Monarquía (1888-1889) y La Libertad (1891); y desde 1909 fue redactor jefe de La Epoca (cfr. www.apmadrid.es). 
diez años, una traducción de los Comentarios de Olympiodoro, y á Michelet reservo San Bernardo. Esta misión es digna de ambos y algún día, amigos míos, me agradeceréis que os la indique."

Dicho esto nos despidió. Cuando bajábamos la escalera nos miramos Michelet y yo en el colmo del asombro, preguntando yo á Michelet qué le parecían los consejos de M. Cousin, manifestándole que por mi parte no me hallaba dispuesto á seguirlos, y si él pensaba enterrarse diez años en las obras de San Bernardo. Nunca, contestó Michelet, ¿dedicaréis á Olympiodoro vuestra existencia?

Por nada del mundo, repliqué, y estuvimos algún tiempo sin volver á casa de M. Cousin. $\gg^{74}$

En la senda del castelarismo cántabro, el montañés Patricio Pérez Cuevas resultó un mediador entre cristianismo y democracia liberal, y él mismo en sus escritos destilaba un compromiso demócrata cristiano, como mostraban sus artículos en el excomulgado periódico La Montaña ${ }^{75}$ En esa línea de cristianismo progresista y no clerical, conciliador en lo político y no ultramontano, Pérez Cuevas describe el problema de la vida social vinculado a la dimensión economicista de relación entre capitalismo y proletariado, en el que tanto las propuestas del «economista ráncio», como aquellas de los «oráculos» colectivistas, golpean «la más excelsa prerogativa [sic] del hombre, la libertad, el ejercicio espontáneo de las facultades, sometiéndole á la tutela abrumadora del Estado, mónstruo, que empieza alhagándole y concluye por devorarle». El economista que ha descubierto unas leyes regidoras universalmente de la fuerza del trabajo, y ha previsto un orden preconcebido, armónico y cosmológico del orden social en la quimera de la economía, ése no desea ni se presta a ninguna «perturbación arbitraria de esas leyes». Así se sigue expresando Pérez Cuevas en El Correo de Cantábria (1882-1905):

«El círculo fatal de Vico se ha roto, para no cerrarse; la humanidad no retrocede, no desanda lo tan penosamente andado; pasaron los tiempos del convento jurídico, y estamos en los de la libertad y responsabilidad del trabajo.

74. M. DE G., «La juventud de Edgar Quinet», La Libertad, a. II, n. 188, Madrid, 22 de febrero de 1891, p. 1 cc. 3-5; cita de Quinet en c. 4.

75. Cfr. Julio de la Cueva Merino, Clericales y Anticlericales. El Conflicto entre Confesionalidad y Secularización en Cantabria (1875-1923), Universidad de Cantabria-ARC, Santander, 1994, p. 127. 
Mal aboga por la redención del trabajador quien aboga por el atentado contra sus derechos naturales, entre los que ninguno se hallará más sagrado que el libre ejercicio de sus facultades..» ${ }^{76}$

Dos periódicos semanales ilustrados continúan dando cuenta de nuestro Vico (el filósofo, no el actor): La Ilustración Ibérica (1883-1898) y La Ilustración Artística (1882-1916). En el primero, desplegados en la tinta ilustrada unos «Apuntes psicológicos morales» del escritor y novelista Juan Justo Uguet, considerado de tendencia tradicionalista antiliberal, ${ }^{77}$ se lee a propósito de las tres principales pasiones que enlazan a los individuos en la sociedad humana («la sociabilidad, el amor y la amistad»):

«Los modernos, ó menos impresionables ó más dados á buscar la razón de todo en el análisis concienzudo de lo tangible, abandonaron las esferas de lo fantástico y maravilloso para internarse en las profundidades de la realidad más positiva en persecución del descubrimiento de la verdad; y yo me veo precisado á seguir su derrotero, siquiera sea para que no se me tilde de nota discordante en el concierto general.

A partir de esta base diré que si la literatura es la expresión de los pueblos, como sentó Vico, las pasiones son el termómetro de la vida moral de las sociedades.» ${ }^{78}$

En el segundo semanario que referimos, un interesante y extenso artículo del escritor y crítico Enrique Funes (1851-1904), titulado «La crítica en

76. P. Pérez Guevas, «Un problema. II. (Continuacion)», El Correo de Cantábria. Periódico de Intereses Materiales, a. X, n. 106, Santander, 4 de septiembre de 1891, pp. 1-2; cit. p. 1 c. 2. Periódico dirigido por Alfredo del Río - «literato de talento, poeta de vena, y gran amigo del jolgorio»-, publicado tres veces por semana y con el lema en la cabecera de «Todo por la Montaña y para la Montaña». Pérez Cuevas prologó la Composiciòn en honor de Castelar, por Emilio Nieto y del Río (folleto de 32 páginas publicado en Santander en 1879); y a él se debe una discutida versión libre — a medias con el regeneracionista Julián Fresnedo de Calzada - de la Historia de cuatro obreros ingleses, de Jonveaux, salida de los tipos de la santanderina Imprenta de La Voz de la Montaña en 1881. De él dice un anónimo cronista: «Patricio Pérez Cuevas, otro buen colaborador de El Correo. Escribe bien, muy bien, especialmente en prosa. Dicen que escribe también preciosos versos; pero el autor de estos párrafos nunca vió poesías de este escritor, digno de ser colocado en el lugar de los excelentes» ([], Nuestros papeles públicos. Apuntes desordenados, por Un Antiguo Periodista, Imprenta Militar y del Comercio, Santander, 1891, p. 65 (cfr. p. 63). Cfr. J. De la Cueva Merino, Clericales y Anticlericales, cit., p. 126.

77. Cfr. Juan I. Ferreras, La novela en España: Historia, Estudios y Ensayos, Biblioteca del Laberinto, Madrid, 2009-2012, 6 tomos; t. IV, p. 190.

78. J.J. Uguet, «La amistad», La Ilustración Ibérica. Semanario científico, literario y artístico, a. IX, n. 452, Barcelona, 29 de agosto de 1891, pp. 550-554; cita p. 551 c. 1. 
el arte del actor», arranca en su primer apartado - de los cinco que consta el artículo - afirmando que no existe aún fundada la Crítica en España, para decir al momento en el segundo párrafo:

«La Crítica es la Filosofía de la Historia, y anda la Ciencia de Vico muy desacreditada en estos tiempos, desde que la ley providencial, como suprema profetisa de los hechos del hombre y mostradora de la inmanencia en ellos de un Dios trascendente, se ha convertido en la ley fatal que los preside, según la Filosofía positiva, y en la simple sucesividad proclamada por los que, no teniendo fe en los indestructibles y legítimos fueros del pensamiento, intentan suprimir la Metafísica, niegan los principios y con ellos la ciencia, tan sólo afirman los fenómenos, y elevan con asombrosa tranquilidad el egolatrismo y su consiguiente lógico, la lucha por la vida, á la categoría de ley suprema de la Historia.) ${ }^{79}$

Si se rechaza la aplicación «de los principios á los hechos», principios no aprióricos sino derivados de los fenómenos, se produce un descrédito racional de ciertas «manifestaciones temporales» de la Filosofía de la Historia, y se desprecia «la ley» que «palpita siempre en el fenómeno» y que le permite al hombre — según esgrime Funes con evidentes tonos viquianos«ver lo que es inmutable, eterno, necesario, filosófico á través de los que cambia y es temporal y contingente, á través de lo histórico» ${ }^{80}$ ¿Hay, entonces según cabría preguntarse a propósito de los planteamientos y argumentos que seguirán en la reflexión de Funes - una razón crítica dramática en el actor y no ya sólo en el actor histórico, sino también en el actor teatral en el ámbito soberano de la fantasía y de la belleza-, o al igual que la oposición entre escolásticos y librepensadores, o la confrontación entre metafísicos y positivistas, también se libra en esta época «una cruzada» entre artistas y críticos?

«Mas á pesar del descrédito indicado, ¿quién niega los milagros de la Crítica [Filosofía de la Historia], aplíquese á esta ó á otra determina-

79. E. FunEs, «La crítica en el arte del actor. (El principio y el hecho)», La Ilustración Artística, a. X, n. 510, Barcelona, 5 octubre 1891, pp. 626-628; cita p. 626 c. 1. Silvestre Manuel Enrique López Funes, natural de Nájera (La Rioja), militar que intervino en Montejurra en febrero de 1870, estuvo destinado en Cuba, Canarias y en Sevilla. Dramaturgo, fue académico correspondiente de la RASBL y en sevilla publicó en 1894 La declamación española. Cfr. José Cascales y MuÑoz, Sevilla intelectual, sus escritores y artistas contemporáneos, Librería de Victoriano Suárez, Madrid, 1896, pp. 94-102. En La Ilustración Artística colaboraron Castelar, Ortega y Munilla, Giner de los Ríos, Clarín, Pardo Bazán [véase infra], Galdós, etc.

80. $I b$. 
ción ó fase de la actividad? Ella contiene en límites estéticos las facultades extraviadas del artista; conviértele en gigante si con alientos viene á la batalla; ella hace enmudecer y pisotea al ignorantón desvanecido; y hoy la hija del pensador de Nápoles, impugnador del método cartesiano, amamantada por la Enciclopedia y la Revolución, ya en las cumbres de Kant, de Hegel y de Krause, suelta las ligaduras del exclusivismo escolástico y declara la sustantividad de la belleza y la independencia del Arte, cuyo fin estético no ha de subordinarse al fin docente ni al fin utilitario ni al fin moral.»>1

Un alegato de crítica estética que nada tiene que ver con la conversión sistémica que desde el lado teológico-político de la prensa, con motivo de la celebración de la festividad de San Agustín, hace La Unión Católica (1887-1899) cuando destaca la influencia del Obispo de Hipona en el sistema filosófico de Vico. El 28 de agosto de 1891 escribe el periodista cacereño - licenciando en Filosofía y Letras por la Universidad Central- Eugenio Fernández Hidalgo, asiduo en las páginas del diario neocatólico, a propósito del Padre de la Iglesia que:

«[...], los católicos admiramos con toda nuestra admiración su vastísima construcción de la filosofía de la Historia, que inspiró al gran Bossuet, y cuyo influjo se ha dejado sentir hasta en los sistemas deterministas ó racionalistas de Vico, Hegel, Condorcet, Krausse [sic] y en el sistema cristiano de Scheleger sobre todo.» ${ }^{\mathbf{2}}$

Y al día siguiente, el jurista y funcionario de Fomento César A. de Arruche (1869-1954) firma una carta al Director del Diario religioso, político y literario en la que dibuja a propósito del autor de la Civitas Dei:

«[...], los arranques de su genio inmortal que le hacen adivinar la gran ley de la Historia en medio de la variedad infinita de los hechos humanos, trazando el camino que el águila de Meaux* debía seguir

81. $I b .$, c. 2 .

82. E. Fernández Hidalgo, «El Águila de Hipona», La Unión Católica. Diario religioso, político y literario, a. IV, n. 1.268, Madrid, viernes 28 de agosto de 1891, pp. 1-2; cita a p. 2 c. 1. El periódico fue continuador del homónimo del órgano del partido confesional integrista y de orientación carlista La Unión, integrado en 1884 en el ala ultratradicionalista del Partido Liberal-Conservador de Antonio Cánovas del Castillo. A diferencia de La Unión (1882-1887), La Unión Católica (1887-1899) arrojó el lastre del carlismo e integrismo aunque siguió la estela ultraconservadora dentro del canovismo, a la vez que abrió tienda de posibilismo neocatólico. (Cfr. ficha descriptiva en HD de la BNE). 
siglos más tarde con raudo vuelo é informando, aunque de lejos, las ideas de Herder y de Vico y de Condorcet en lo que éstas tienen de verdadero y aceptable, $[\ldots] \gg .{ }^{83}$

Al año después, en una glosa a San Agustín firmada por el escritor, historiador y biógrafo José Ignacio Valentí y publicada en Palma de Mallorca por El Isleño (1858-1898/99), ${ }^{\mathbf{8 4}}$ escribe sobre La Ciudad de Dios, considerada «briosa y triunfante apología del cristianismo, y el primer ensayo de la verdadera filosofía de la Historia, cultivada más tarde por Bossuet», que:

«La acción providencial de Dios en la humanidad, tal es la idea que informa la concepción agustiniana, idea que, como todas las grandes ideas, se ha perpetuado á través de los siglos, á pesar de las negaciones del racionalismo, y palpita en el fondo de todas las teorías y trabajos acerca de la filosofía de la historia. Porque no es solo en el Discurso sobre la Historia Universal de Bossuet, donde reaparece; encuéntranse también vestigios y reminiscencias de ella en la Scienza nuova de Juan B. Vico con sus corsi é recorsi [sic], y en las Ideas sobre la historia de la humanidad de Herder, y en la perfectibilidad indefinida de Condorcet, y en las edades armónicas de Krause, y en la teoría hegeliana, y, por decirlo de una vez, en todas las que sustenta el panteísmo acerca de la Filosofía de la historia.. ${ }^{85}$

Una columna de "Kasabal", ${ }^{86}$ titulada «El consuelo», elabora una interesante triangulación a partir de un artículo de Emilia Pardo Bazán (1851-

83. C.A. DE ARruche, «Carta del Escorial», La Unión Católica, a. IV, n. 1.269, Madrid, sábado 29 de agosto de 1891, p. 2 c. 3-4; cita en c. 3. [*Se refiere, como es sabido, a J.B. Bossuet (1627-1704), obispo de Meaux y autor del Discours sur l'Histoire Universelle (1681)]. César Antonio de Arruche y Villanueva (natural de Guadalajara y fallecido en Madrid), Doctor en Filosofía y Letras, fue uno de los finalistas en la oposición de la cátedra ovetense de Historia del Derecho que ganó Rafael Altamira en 1897. Ordenador de Pagos en el Ministerio de Fomento, asesor jefe del Banco de España (1937) y en 1938 subgobernador segundo del BE; era Gran Cruz Corona de Italia y Comendador Isabel La Católica.

84. J.I. VAlEnTí, «San Agustín», El Isleño. Periódico de intereses materiales, a. XXXVI, n. 11.663, Palma de Mallorca, sábado 27 de agosto de 1892, p. 1 cc. 1-3. El Isleño (1858-1898/99) comenzó siendo órgano del Partido Liberal, pasó luego al Partido Progresista, para terminar —así en la época a la que nos referimos - afín al conservadurismo. José Ignacio Valentí Forteza (Palma 1836-1924 Barcelona), doctor en Filosofía y Letras y licenciado en Teología, ambos títulos en Valencia; socio de la Academia Barcelonesa y autor, entre otras obras, de La mujer en su historia.

85. $I b$., c. 2 .

86. Pseudónimo del periodista José Gutiérrez Abascal (1850-1907) usando un anagrama de su segundo apellido. Además de escritor y periodista, actuó en política como diputado a Cortes desde 1889 a 
1921) publicado en la revista La Edad Moderna (a propósito — por parte de la literata y ensayista gallega — del tratado La dicha de existir, autoría del optimista ontológico sir P. John Lubbock). "Kasabal" confronta la biblioteca recomendada por el escritor y parlamentario británico, sir Lubbock, con la propia biblioteca del padre del pesimismo existencialista, Arthur Schopenhauer, más del gusto de la académica y novelista española. Vico, Schopenhauer y Pardo Bazán ubicados en un mismo plano biobiliográfico no sólo nos desvelan una posible lectura schopenhaueriana de Vico, cuanto al menos la existencia de la obra de éste en la biblioteca del alemán; además de la inclusión del napolitano en una relación de autores hispanos. Destaca "Kasabal" en la ya referida columna publicada en La Correspondencia de España (1860-1925), y al mes reproducida en el diario jerezano El Guadalete (1873-1936), la preferencia de Pardo Bazán por la biblioteca del autor de La angustia que por la recomendada por el político inglés. De esta manera, dice José Gutiérrez Abascal bajo el pseudónimo, refiriéndose a la elección de la biblioteca a recomendar, que:

«á la insigne escritora le gusta mucho más la de Schopenhauer, que nos ha dado á conocer un volumen publicado en Leipzig con el título de Aedita und inedita Schopenhaueriana.

Según este curioso libro, en la biblioteca del maestro oficial del pesimismo figuraban además de obras de Mariana, de Sabonde, Suárez, Huarte, Gracián y Vico, sino [sic] obras más regocijadas como la Vida y hechos del pícaro Guzmán de Alfarache, las Novelas ejemplares de Cervantes, Las brujas en Zugarramundi, de López Martínez; la Vida del Lazarillo de Tormes. El Buscón, de Quevedo; el Fray Gerundio de Campasas. Estebanillo González, Las fábulas

\footnotetext{
1903. Fue cofundador en 1890 y durante doce años director del diario conservador El Heraldo de Madrid (1890-1939), de tendencia demócrata-liberal. Curiosamente, en 1892 dicho periódico publicó por entregas en su sección «Biblioteca de 'El Heraldo'» el éxito de Alejandro Dumas La San Felice (1864), novela que relata el encarcelamiento y posterior ejecución por decapitación en Nápoles — ciudad en la que el escritor galo vivió cuatro años, tras su llegada con Garibaldi- de Luigia Sanfelice por colaboracionista con los franceses durante la fundación por republicanos napolitanos, junto con el ejército invasor, de la efímera República Partenopea el 24 de enero de 1799. La publicación traduce el diálogo en el cap. LXXXIV acerca de Vico entre el señor Duque, Nicolino, y su 'humanizado' carcelero Roberto Brandi, Gobernador de la fortaleza de San Telmo, quien le ofrece lectura y al que el Duque abronca por no conocer la obra del famoso autor napolitano hijo de un librero (vid. El Heraldo de Madrid, Diario Independiente, a. III, n. 496, viernes 11 de marzo de 1892, pp. 3-4 (pp. 111-118 de la serie a pie de páginas), en especial p. 4 (pp. 116-117 de la serie). Cfr. original francés La San-Felice, Michel Lévy Frères - Librairie Nouvelle, París, 1864, tomo V, pp. 114-116 (trad. al español de los vols. I y III por Federico de la Vega y Fernando Garrido, Abel Ledoux ed., París, 1865).
} 
literarias, de Iriarte, y El café, de Moratín.

Es, pues, mucho mejor la biblioteca de Schopenhauer, que la que recomienda Lubbock. $\rangle^{87}$

En 1892 se produce la dimisión de Cánovas y a finales de año forma gobierno Sagasta. Circular alternancia. Como otras veces, continúa de vez en cuando apareciendo alguna página haciéndose eco del tópico de la circularidad de la historia en Vico. Así, en diarios de derechas como el notoriamente monárquico La Época (1849-1936), en cuyas «Crónicas madrileñas» rememora el periodista y crítico Francisco Fernández Villegas (1856-1916), bajo el pseudónimo "Zeda", ${ }^{88}$ a propósito de la tendencia epocal a la imitación y la moda de la repetición, los círculos del napolitano. Se alinea de este modo Fernández Villegas con la doctrina del tiovivismo histórico:

«En la alimentación, en el traje, en los vicios, en las pasiones, hasta en los mismos crímenes se observa la tendencia al remedo, de tal suerte que, y al fin y á la postre, considerada con cuidado la historia, antójasenos, como Vico sostenía, que la humanidad, en vez de caminar en línea recta, no hace otra cosa sino describir un círculo siempre

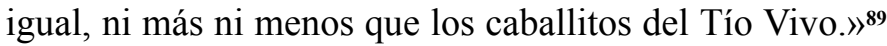

La primera del diario católico El Siglo Futuro (1875-1936) estampada el 8 de abril del mismo año de 1892, pone a Vico como refuerzo del dictamen según el cual las doctrinas socialistas y anarquistas, unidas a la deja-

87. "KasabaL", «El consuelo», La Correspondencia de España. Diario político y de noticias. Eco imparcial de la opinión y de la prensa, a. XLIII, n. 12.352, Madrid, domingo 31 de enero de 1892, p. 1; cita p. 1 c. 5. Idem: El Guadalete. Periódico político y literario, a. XXXVIII, n. 11.002, Jerez de la Frontera, jueves 4 de febrero de 1892, p. 2 c. 2.

88. Pseudónimo de Fernández Villegas «en las críticas literarias de La Época, 1894-95, y después, por algún tiempo, en las de El Imparcial» (Maxiriarth [Eugenio Hartzenbusch], Unos cuantos seudónimos de escritores españoles; con sus correspondientes nombres verdaderos, pról. de J. Fernández Bremón, Est. Tipográfico Sucesores de Rivadeneyra, Madrid, 1904, p. 141). Escritor y dramaturgo, crítico teatral y literario, periodista, traductor, en todas sus facetas Zeda es fiel notario de la crisis de fin de siglo que marcará a la Generación del '98, a la que espiritualmente llegó a acercarse, influyendo quizás su amistad con Unamuno. Fernández Villegas fue redactor en nómina de La Época, periódico madrileño de primera línea y durante años - hasta 1865 - órgano de la Unión Liberal y luego punta de lanza del canovismo restaurador; hasta convertirse en órgano del Partido Conservador de Cánovas en la década de 1875 a 1885.

89. “ZEDA”, «Imitaciones», La Época, Últimas noticias y telegramas de la tarde, a. XLIV, n. 14.195, Madrid, jueves 10 marzo 1892, p. 1 cc. 3-4; cita a c. 3. 
ción liberal, están conduciendo la sociedad hacia el abismo. Resuena el repiqueteo no sólo ideológico ultraconservador sino incluso apologético sobre la civilización europea del fustigador Ensayo sobre el catolicismo, el liberalismo y el socialismo (1851) de Donoso Cortés. Al sentido contrarrevolucionario de éste se une ahora el pesimismo trágico social que aprecia «en grave riesgo los fundamentos sobre los que descansa la sociedad». Dice expresamente el segundo párrafo del artículo editorial de dicho viernes de abril:

«No de ahora, sino de mucho tiempo á esta parte, está anunciando EL Siglo Futuro que la sociedad camina á pasos agigantados á su completa ruina, que por el camino que llevan los pueblos y gobiernos imbuidos en las detestables enseñanzas del liberalismo, no puede llegarse sino á los abismos del caos social, donde toda noción de justicia se desvanece, toda iniquidad tiene su asiento y todo derecho es atropellado por el hecho brutal triunfante, y que lejos de avanzar en la senda de la perfección ó del progreso indefinido, como se dice en la jerga exótica y enrevesada del liberalismo, van las sociedades retrocediendo á los tiempos de la barbarie, como si se hubieran propuesto hacer buena la teoría filosófica del famoso círculo de Vico.

No una, sino muchas veces, no de tarde en tarde, pero casi diariamente, hemos señalado los peligros que para los pueblos se derivan de las teorías del socialismo y del anarquismo, y en tal concepto no podemos ser, no ya sospechosos, pero ni siquiera calificados de tibios en la defensa de cuanto atañe al orden social, cuyos fundamentos hemos defendido contra toda suerte de adversarios. $\rangle^{\mathbf{9 0}}$

En términos parecidos se refiere el narrador montañés Evaristo Rodríguez de Bedia en El Atlántico de Santander (1886-1896), quien comienza su relato «El lobo del Ardeche» diciendo:

«Sabido es, porque la historia lo tiene suficientemente demostrado y la filosofía nos permite afirmarlo sin dudas ni vacilaciones, que el instinto del hombre, sus pasiones, sus anhelos, sus ideales, avances y retrocesos como cuerpo social [...] son siempre los mismos... ¿Tendrá razón el italiano Vico al exponer su teoría fatalista del círculo opresor?» ${ }^{91}$

90. [ ], «Distingamos», El Siglo Futuro. Diario Católico, a. XVIII, n. 5.138, Madrid, viernes 8 abril 1892, p. 1 c. 1. Por entonces el periódico estaba dirigido por Ramón Nocedal, hijo del carlista fundador y primer director durante una década, Cándido Nocedal.

91. E. RodríGueZ DE BEDIA, «El lobo del Ardeche - Narración de todos los tiempos», El Atlántico, a. VII, 
Por su lado, el frenópata valenciano José María Escuder argumenta en El Imparcial (1867-1933) la exaltación de esa época de tolerancia en que vive. Justo para denunciar que ya no se persiga en ella la verdad ni se denoste el error; y, peor aún, para lamentarse de que ya no se pague con la vida o al menos con el escarnio público la osadía de afirmar una hipótesis, como Bruno, Vanini, Galileo, Buffon... «Hoy todo el mundo puede decir lo que se le antoje. Es libre, hasta el delirio.» Pero hay que distinguir, según Escuder, entre tolerar una creencia y tolerar una acción: «no es lo mismo invocar espíritus que considerar que la sociedad toda ella está podrida y descompuesta y tratar de desinfectarla con la dinamita». ${ }^{\mathbf{2}}$ Los tiempos que corren son, según Escuder, propicios para la aparición de «ingenios con mixtura de insensatez» o «aventureros del pensamiento» cuyo «pensar carece de exactitud, orden y realidad»; es decir: carecen de disciplica, de método y de fundamento. Así se refiere el polémico autor a aquellos «agitadores» de la «sonata marxista» que buscan que un alto número de seres humanos piense una sola idea. ¿Mas qué sucede si ésta no se adapta a la realidad? «¿Qué importa que en un día dado miles de obreros expresen la misma idea en todas las naciones? El

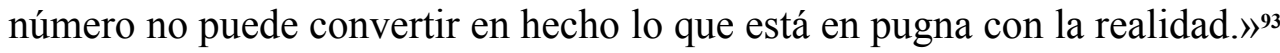
Libre es el delirio en la palabra, ha esgrimido antes el médico psiquiatra, mas no en la acción social, civil o histórica; a pesar de que las ideas, por desva-

n. 129, Santander, lunes 9 de mayo de 1892, p. 2, cita c. 2. El Atlántico fue un periódico regionalista de orientacion liberal dinástica y católica («posibilista»). Evaristo Rodríguez de Bedia († 1944), escritor y periodista cántabro además de corredor de comercio, fue socio fundador del Ateneo de Santander.

92. Escuder, «Los agitadores», El Imparcial. Diario Liberal, a. XXV, n. 8.971, Madrid, miércoles 11 de mayo de 1892, p. 2 c. 3. Periódico fundado por Eduardo Gasset y Artime (1832-1884), innovador e influyente — sobre todo durante el Sexenio Democrático — y el de mayor tirada (el número anterior al aquí citado tuvo una tirada de 77.550 ejemplares), El Imparcial propició el periodismo moderno y la transformación de la prensa al modelo del siglo XX. Hizo gala de realismo político durante la Restauración, a pesar de oponerse a la misma desde una neta posición liberal, enfrentándose al otro gran periódico diario del momento, La Época, ya declaradamente dinástico y canovista.

93. $I b$., c. 4. José María Escuder y Jiménez (valenciano nacido en 1853), médico en el Manicomio de Carabanchel y autor entre otras obras de Locos y anómalos (1895). Médico legal y psiquiatra forente, actuó de perito psiquiátrico para la defensa en el famoso «caso Morillo» en el que se empeñó en demostrar la locura del reo (RICARDo CAMPOS, El Caso Morillo: Crimen, locura y subjetividad en la España de la Restauración, Frenia-CSIC, Madrid, 2012; reseñado en Asclepio, t. 69, n. 1, 2017). Ideológicamente de tendencia socialdemócrata. «También se ocupó de asuntos sociales y relacionados con el derecho público, interviniendo en ruidosas polémicas en el Ateneo y en otras cátedras» (dicen PILAR DE JaIME Ruiz y José M. DE JAIME LORÉNS en «Presencia de la palabra "psiquiatría” en los diccionarios y en la prensa española (1855-1900)», Revista de la Asociación Española de Neuropsiquiatría, 39, n. 135, 2019, pp. 67-90; p. 78). 
riadas que sean, puedan ser esgrimidas por «curanderos» compuestos de «mezcla extraña de razon y de locura» y a quienes «la ambición y la audacia les impulsa á capitanear á los pobres de espíritu mostrándoles el señuelo de su redencion.» ${ }^{\mathbf{9 4}} \mathrm{Sin}$ embargo, esa «actividad devoradora del espíritu» ha sido a veces también beneficiosa para la humanidad, casi respondiendo a una especie de heterogonía de los fines.

«Los locos han prestado á veces grandes servicios á la humanidad. Ningun gran ingenio hubo sin la mixtura de demencia, decía Aristóteles. Y en efecto, Pascal, por querer saber la razon de todas las cosas, perdió la suya; Hobbes sufría alucinciones; Vico se volvió loco, buscando la filosofía de la historia; Lutero hablaba con el demonio; Rousseau infundió su delirio de persecuciones á los jacobinos; Comte enloqueció; Schopenhauer, un insensato de ingenio, ha engendrado el sombrío pesimismo; Krause, un enfermo del cerebro, inventó una nueva metafísica.» ${ }^{95}$

Un plagio de este artículo de Escuder tiene lugar ocho años más tarde en el Diario de Avisos de Segovia (1899-1916) de 17 de junio de 1900, en cuya página 2, sobre la firma de Felipe Aparicio se articula una columna con fragmentos extraídos del cuerpo central del artículo de Escuder, en concreto de sus párrafos sexto a undécimo. Diríamos, medio en broma, que el reconocimiento de Vico es tal que merece hasta ser plagiado. ${ }^{\mathbf{9 6}}$

El mismo argumento manejado por Escuder acerca de la locura de los genios cargados de melancolía se reproduce en otra lista de grandes nombres, subrayándose la idea de que cualquier gran pensador «se contrista al descubrir lo poco que vale la humanidad». Esta selecta lista de distinguidos melancólicos aparece en mayo de 1894 en el El Diario de Murcia, con ejemplos como San Ignacio, Lutero, Lord Byron, Newton, Pascal, Rousseau, Gilbert, Larra...

«El dolor más atroz, es el dolor del hombre de talento que tiene la conciencia íntima de la gloria á que es acreedor, y sin embargo se pudre y se extingue en la oscuridad. Cristobal Colon, Galileo,

94. $I b .$, c. 3 .

95. $I b$.

96. F. Aparicio, «Los locos han prestado á veces grandes servicios á la humanidad», Diario de Avisos de Segovia. Defensor de los intereses de la Provincia, a. II, n. 437, Segovia, domingo 17 de junio de 1900, p. 2, c. 3. (Cfr. el plagio del artículo de J.M. Escuder, «Los agitadores», El Imparcial. Diario Liberal, antes citado, p. 2 cs. 2-4; c. 3; vid. en nota 92 supra). 
Copérnico, Bacon, Vives, Descartes... y otros mil, tuvieron que sufrir ese dolor imponderable. [...] La melancolía penetra por mil vias en los pensadores distinguidos..>97

Aunque durante la Restauración no eran pocos los "mestizos" (católicos que abrazaban el liberalismo; como quizás, por ejemplo, Juan Valera), sí que eran muchos los "neos" (neocatólicos) a veces fanáticos en lo político y también integristas en lo religioso. En esta última senda, y ahora durante la era "fusionista" en política, nuevamente La Unión Católica ataca al racionalismo, centrándose en la falta de originalidad para buscar el elemento sobre el que la historia se desarrolla, pues los modernos racionalistas «al fin y al cabo no hacen más que aplicar las doctrinas de Vico: no son ni aún inventores», firma El Licenciado, Calvo Martín, Presbitero. ${ }^{98}$

En el mismo periódico explica Leopoldo Pedreira (1869-1915) la teoría providencialista del progreso expuesta por el fraile agustino Eustoquio Uriarte (1863-1900) en el discurso de inauguración del Real Colegio del Escorial, sobre la Historia Filosófica. ${ }^{99}$ La tesis de Uriarte ahí resumida es la de que «el progreso tiene el doble carácter de libre y providencial», y que por medio de esa dialéctica entre activismo humano y dirección divina se cifran los misterios de la historia. Según sostiene Pedreira, fray Uriarte toma parti-

97. [ ], «La melancolía de los grandes hombres», El Diario de Murcia, a. XVI, n. 6.262, sábado 5 de mayo de 1894, p. 2 c. 2. La columna no tiene firma. Publicada también en el diario La Lucha, a. XXIV, n. 5.268, Gerona, sábado 26 de mayo de 1894, p. 2 c. 4 y p. 3 c. 1; y reaparecida más de una década después en El album ibero-americano, a. XV, n. 41, Madrid, 7 de noviembre de 1907, p. 485 cc. 2-3, firmada esta vez por Evelio del Monte. Con un añadido de 5 párrafos al inicio y de 4 al final aparece publicado el mismo citado texto completo en La Unión. Periódico de primera enseñanza, a. XV, n. 25, 28 de junio de 1894, pp. 7-8 (cita a Vico en p. 8 c. 1), firmado por P. Monláu. Bajo el pseudónimo de "Evelio del Monte" publicaba en numerosos periódicos y revistas la escritora y periodista de origen catalán Josefa Pujol de Collado († 1904); conocida helenista que fue la directora desde 1879 de la revista El Parthenón y que siempre en sus «trabajos ha seguido muy consecuentemente todos los puntos que se relacionan con el feminismo», según Manuel Ossorio y Bernard (Ensayo de un catálogo de Periodistas españoles del siglo XIX, cit., p. 361).

98. Calvo Martín, «Jesucristo» (II), La Unión Católica. Diario religioso, político y literario, a. VI, n. 1.440, Madrid, martes 12 de abril de 1892, p. 1 c. 2.

99. Fray Eustoquio Uriarte (1863-1900), musicólogo natural de Durango, obsersionado con la restauración del canto gregoriano, autor de un Tratado teórico-práctico de canto gregoriano, según la verdadera tradición (Imprenta de Luis Aguado, Madrid, 1890) y de un volumen de Estética y Crítica Musical (recopilatorio póstumo por el padre Villalba en 1904), además de otros estudios sobre historia, estética y crítica musical. Cfr. la biografía a cargo de José Antonio Arana Martija, «En el 75 aniversario de su muerte. El padre Eustoquio de Uriarte», Boletín de la Real Sociedad Bascongada de los Amigos del País, a. XXXI, cuadernos $3^{\circ}$ y $4^{\circ}$, 1975, pp. 95-114 (en especial pp. 98 y ss.); y cfr. la extensa esquela biobibliográfica de F.J. Campos y Fernández de Sevilla OSA en Dbe Real Academia de la Historia, en http://dbe.rah.es/. 
do por «la calumniada Edad media», arremete contra los clasicistas del Renacimiento no menos que contra los románticos posteriores, y más aún:
«Declárase enemigo de la Filosofia de la Historia y hace suya la frase de Balmes, quien decía que "la Filosofía de la Historia es á menudo Filosofia del Historiador." Opina que en esta suerte de estudios solo es admisible la Historia Filosófica, unida íntimamente á la consideración misma de los hechos $[\ldots . .]_{\gg .}{ }^{\mathbf{1 0 0}}$

Se presta así Pedreira a exponer la opinión crítica de fray Uriarte sobre la doctrina viquiana de la presunta circularidad de la historia, que el propio recensor finaliza apostillando y abriéndole un respiradero a la misma:

«Opina que la línea que sigue el progreso no es un círculo, como quería Vico, ni una espiral como han pretendido otros; dice el P. Uriarte que semejante afirmación implica un fatalismo y se enlaza con las doctrinas de la perfectibilidad indefinida, de la selección de las razas, del progreso por la memoria y demás teorías que desde Bacón, á través de Descartes y Pascal, han venido sosteniendo las escuelas experimentalistas.»101

Sin embargo, y ahora en opinión propia del catedrático gallego:

«En todo estamos conformes con el erudito pensador agustino; pero nos parece que aunque llegase á demostrarse que el progreso es un círculo, quedaría á salvo la libertad humana[.] Pues qué, ¿la vida individual no es acaso un ciclo no interrumpido de nacimiento, crecimiento y muerte? ¿Por qué las civilizaciones no han de seguir en su curso la misma ley cada generación? [...] El progreso no será quizás un círculo; pero hay una verdad innegable: el progreso fue hasta aquí un círculo no interrumpido.» ${ }^{\mathbf{1 0 2}}$

100. L. Pedreira, «Dos opúsculos del P. Uriarte» (I), La Unión Católica. Diario religioso, político y literario, a. VII, n. 1.699, Madrid, viernes 20 de enero de 1893, p. 2 c. 4. Leopoldo Pedreira Tábo (18691915), natural de Coruña; Dr. en Filosofía y Letras por la Universidad Central y discípulo de Sánchez Moguel; catedrático de Geografía e Historia profesando en diversos Institutos de Enseñanza (entre ellos en Baeza y en Cuenca, además de La Laguna; ciudades en las que colaboró en distintos proyectos periodísticos). Pedreira era miembro correspondiente por Cuenca de la Real Academia de la Historia; y correspondiente de la Real Academia Galega. Por esta época que tratamos acabada de publicar su obra Concepto de la Patria (Librería de F. Iravedra, Madrid, 1892). Un año antes de su muerte publicaría sus Cuadros de Historia Universal (1914). De ideología conservadora-liberal, sin reñir con la modernidad, también llevó a cabo estudios sobre el regionalismo en Galicia.

101. $I b$.

102. Ib., p. 2 c. 4 - p. 3 c. 1 . 
Queda de este modo matizado y, en cierta manera, corregido el discurso del musicólogo agustino, aludiendo Pedreira en este caso al valor del sentido viquiano de los ciclos históricos.

Del mismo modo que, en otro plano de crítica (ahora destinada a la recepción de Vico en la escuela valenciana de jurisprudencia), apostilla el notario Rafael Peñalva al jurisconsulto, catedrático y sociólogo krausista Eduardo Pérez Pujol (1830-1894). En la cuarta entrega de su artículo «El libro Savonarola y la cultura valenciana» (1893), Peñalva esgrime que la desviación de las grandes corrientes desde el siglo XVI es un fenómeno no puntual sino «de carácter definitivo y permanente» de nuestro país dentro del orbe de la civilización presente, ya de por sí herida y agónica. Se alega que los «ideales» humanos perseguidos por la humanidad desde el incio del cristianismo «están para desaparecer». Y como adelantándose a la tesis orteguiana de la dialéctica entre ideas y creencias, afirma Peñalva que «la crisis por que atraviesa nuestro espíritu es tan absoluta y dolorosa porque no se vislumbran todavía los ideales y elementos que vengan á transformar nuestra empobrecida sociedad». ${ }^{\mathbf{1 0 3}}$ Decaídos - tras un siglo de régimen «que se funda en los derechos inmanentes del individuo»— los sentidos morales en abstracciones moralistas, «nos encontramos con que el ciudadano gime aplastado bajo el peso enorme de la propia obra á quien dió vida el Estado». ${ }^{104}$ De tal modo que, frente a esta «tendencia individualista» que ha predominado en toda la modernidad, engendrando radicales «concupiscencias antisociales» a partir del egoísmo, sucede que

«llegada nuestra época, cerrado el ciclo de su evolución, obrando como entes de razón y pensando lógicamente, sin garrulerías pseudo filosóficas y parlamentarias, hemos visto, llenos de estupor y sorpresa, que el individualismo nos lleva en derechura á la anarquía en política, al escepticismo en filosofía, al ateísmo en religión, al nihilismo social, [...]». ${ }^{\mathbf{1 0 5}}$

Frente a tanta disolución en la postindividualista caída de la sociedad, Peñalva propone la asociación como acción intermediaria entre el individuo y el

103. E. PeÑalva, «El libro Savonarola y la cultura valenciana», La Ilustración Ibérica, Semanario científico, literario y artístico, a. XI, n. 536, Barcelona, 8 de abril de 1893, pp. 214 [la 2ª cc. 2-3 y 215 [la $3^{a}$ ] cc. 1-2; cita p. $2^{\text {a }}$ c. 3. E. Pérez Pujol, sociólogo y procurador de los gremios; catedrático de Derecho (Santiago, Valladolid, Valencia), fue rector de la universidad valentina (1869-1873).

104. $I b$.

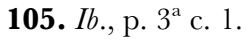


Estado; único régimen capaz de encarar, sobre la base de la solidaridad y la acción colectiva, una transformación social: el régimen corporativo. Este «intermediario» a medio camino de la reforma, toma hechura y manifestación en las cámaras de comercio, de industria, etc.; gremios, sindicatos, asociaciones profesionales, cooperativas laborales, etc. Así, lo que para algunos «defensores del hombre aislado y autónomo» parecerá un «retroceso», en ningún caso habrá de suponerlo quien defiende al individuo integrado en su naturaleza sociable en vez de ir en contra de ella. Es motivo por el que, según Peñalva, ha venido durante años propagando el ilustre jurista y publicista valenciano - aunque salmantino de nacimiento - Eduardo Pérez Pujol el anuncio de la «próxima metamorfosis» hija de la «grave crisis por que atraviesa nuestro espíritu y todo el engranaje social». Lástima que la rama de olivo portada por el reputado orador krausista no fuera correctamente recepcionada, al igual que le ocurrió a Vico, según sentencia Peñalva como colofón de su artículo, sin necesidad de más comentarios:

«El señor Pérez Pujol ha cumplido, por lo que respecta á España, una gran misión histórica en los últimos treinta años. Empero, á éste ha venido á sucederle en cierto modo lo que á Vico con su Scienza Nuova: no ha sido comprendido ni secundado en poco ni en mucho por sus contemporáneos, ni menos por el rancio clasicismo de la escuela valenciana.» ${ }^{\mathbf{1 0 6}}$

En los meses de marzo-abril de 1894 se establece el tratado de paz entre España y Marruecos que pone fin a la primera guerra del Rif contra las cabilas norteñas que asediaban Melilla. Durante ese mismo año, el penalista José García Romero de Tejada recuerda en el diario - ya anteriormente referido supra - El Guadalete (1873-1936) «la conocida afirmación de Vico “de que el tiempo no crea ni destruye el Derecho", cuya sustancialidad es eterna»; y para formular esta similar ley de la termodinámica jurisprudencial — permítasenos la metáfora - completa García Romero la tesis de Vico con el «profundo aserto de Ahrens "de que el tiempo no es otra cosa que una simple forma ó modo de transformación en el mundo, no es la razón ni del nacimiento, ni de la desaparición de un derecho" $[\ldots] \gg{ }^{107}$

106. $I b .$, p. $3^{\text {a c. } 2 .}$

107. J. García Romero de TejadA, «Notas bibliográficas. [Teoria della Transformazione dei capitali di Camillo Supino, Bocca Fratelli editores, Turín]», El Guadalete. Periódico político y literario, a. XL, n. 11.779, Jerez de la Frontera, martes 7 de agosto de 1894, p. 1 c. 2. José García Romero de Tejada, juez de primera instancia y de instrucción, jubilado en mayo de 1908 como Magistrado de la Audiencia de Madrid, es el autor de El libro del jurado y del manual Clave de aplicacion de penas. Por las fechas de este artículo, García Romero ejercía de abogado fiscal de la Audiencia de Albacete. 
Otro recurso a Vico, en verano del mismo año, aparece en el diario conservador santanderino La Atalaya (1893-1927) con objeto de confirmar, en «medio de esta época descreída», que la religión es propia de la naturaleza humana. Razonamiento de la línea católica que, sin embargo, no duda en utilizar tanto a Vico como a Comte a la hora de confirmarlo, aunque - frente al fuerte impulso de la «hipocresía laica»— sea aprovechando la inercia del contrario:

«El género humano, cuya historia se ha dividido en edades, á ejemplo del hombre, ofrece el mismo fenónemo que no es extraño ni singular para los que saben que el alma es por naturaleza religiosa.

Juan Bautista Vico por una parte, y por otra los sociólogos positivistas modernos, dicen - y es verdad, como histórica, innegableque en la edad que apellidan "infancia de los pueblos", la religión lo es todo y todo se refiere á ella: la ciudad, la familia, los astros, los meteoros, la poesía... las leyes... toda la vida, toda la ciencia, toda la cultura aparece entonces informada por la idea religiosa.

[...] y ó nada valen las comparaciones entre las edades del hombre y las de los pueblos, ó es evidente que, pues religiosa fue y es la infancia de los pueblos, religiosa tiene que ser la del hombre; $[\ldots] \gg .{ }^{\mathbf{1 0 8}}$

En el decenal educativo El Pacense, el director de la Escuela de Artes y Oficios, José del Solar, abre portada el día de Navidad de 1894 con un artículo en el que el escritor pacense aboga por la ilustración de la clase obrera capacitándola para introducirse en las corrientes de las distintas escuelas filosóficas, la ética y la literatura, y todo ello gracias a una nueva y única ciencia: la ciencia histórica, por la que «en la actualidad se puede llegar al conocimiento de las sociales, de las naturales, de las estéticas y de las filosóficas».. ${ }^{109}$ Tal es así que, entusiasmado por esa ciencia en que transparece «la silueta del progreso», comienza Solar sus reflexiones diciendo:

«San Agustín, Rossuet [sic] y Vico abrieron á la ciencia histórica dilatados horizontes. A su vasta inteligencia se debió la transformación de un conjunto de hechos inconexos en un todo homogéneo,

108. [ ], «La catequesis», La Atalaya. Diario de la mañana, a. II, n. 550, Santander, jueves 12 de julio de 1894 , p. 1 cc. 2-3; cita c. 3.

109. J. DEL SOLAR, «Reflexiones sobre la Historia», El Pacense, a. IV, n. 114, Badajoz, 25 de diciembre de 1894, p. 1 c. 2. Solar fue colaborador de El Heraldo de Badajoz y Redactor-jefe de La Defensa (1884-1890), periódico liberal dinástico, donde utilizaba el pseudónimo de "Numa" (cfr. Román Gómez ViLLafranca, Historia y Bibliografia de la Prensa de Badaloz, Est. Tip. La Económica, Badajoz, 1901, pp. 175-176). 
foco brillante que facilitó la investigación de los destinos de la humanidad y el descubrimiento de los principios que influyen incesantemente en el desarrollo de las leyes del progreso.» ${ }^{110}$

Un manifiesto entusiasta de esa nueva ciencia histórica fue el eminente político republicano demócrata y filósofo secular Emilio Castelar (18321899), quien, como ya es conocido, citó a Vico algunas veces en sus discursos académicos y en artículos de prensa, tanto en revistas como en diarios. ${ }^{111}$ Escribe quien hubo sido el último de los filósofos presidentes de la I República unos meses entre 1873 y 1874, mas en esta ocasión recordando el republicanismo democrático y católico del historiador italiano Cesare Cantú (1804-1895), que

«cuando nosotros éramos chicos, y habíamos encontrado por toda Historia universal el Discurso de Bossuet y el gran libro de Vico, elocuente aquélla y éste profundo, pero los dos de una gran deficiencia, por no haber pasado del siglo XVII, en que se publicaran, ${ }^{*}$ y haber tenido el uno un criterio sobradamente ortodoxo como el otro sobradamente profano, recibimos con alegría este libro de Cantú, que nos presentaba en una serie lógica y con un verbo inflamadísimo el desarrollo de la humanidad en el tiempo, desde un punto de vista muy parecido al de Bossuet, su maestro, y al de Vico, su compatriota, pero profesando siempre y manteniendo siempre la teoría del progreso, la democracia dentro del catolicismo, y para encarnar uno y otro principio la república cristiana.»1 ${ }^{\mathbf{1 1 2}}$

Y si de catolicismo político se trata — desde la vertiente no ya progresista y liberal del mismo, como en algún caso anterior mostrado, sino ahora en la línea integrista y carlista del catolicismo «oficial»—, téngase en cuenta el

110. $I b .$, p. 1 c. 1 .

111. Cfr. nuestros estudios ya citados, adendas a El espejo de la época: Ad. I «Destellos de Vico en revistas culturales y literarias españolas ...» (pp. 366-367 y en p. 381 notas 92-94); Ad. III «Ráfagas de Vico en la prensa diaria ...» (en especial el apdo. II); y Ad. IV «"Aludir con la palabra Vico”. Nuevas ráfagas viquianas ...» (especialmente el apdo. 2, pp. 34-35 y 39-40).

112. E. CastelaR, «Murmuraciones europeas (I)», La Ilustración Artística. Periódico Semanal, a. XIV, n. 694, Barcelona, 15 abril 1895, p. 274 completa, cita c. 3, apdo. III. [*Si bien la obra del francés es de 1689, extrañamente yerraría Castelar al ubicar la publicación de la Scienza nuova de Vico en el s. XVII: la primera edición es de 1725 y la tercera y última de 1744, año de la muerte del napolitano. Debe de tratarse de una errata de imprenta]. 
trato que Vico merece en la monografía distinguida en el certámen literario de Alicante el 7 de agosto de 1890, publicada cinco años más tarde en la Imprenta alicantina de Manuel y Vicente Guijarro con el título Influencia de La prensa periódica en la cultura e ilustración de los pueblos, autoría del político tradicionalista Vicente Calatayud Bonmatí (1846-1908), «jefe de los carlistas alicantinos» y colaborador primero de El Alicantino (1888) y más tarde de $E l$ Nuevo Alicantino (1895). ${ }^{113}$ Precisamente en la sección «Folletín de El Nuevo Alicantino» se publica, por entregas de cuatro páginas, la monografía de Calatayud. Disertando sobre lo divino y lo humano, en el capítulo VI «El periodismo es discordia social», esgrime el autor que el periodismo (por su naturaleza discutidor y con pluralidad de opiniones) abole la unidad religiosa sin la cual, por otro lado, no es posible la paz social. A favor de este enrevesado argumento cita el autor la Scienza nuova de Vico:

«"Un cuerpo político no se constituye en nación sino cuando tiene un alma nacional", decía Rogier, hablando de la unidad de enseñanza entre católicos y protestantes (1), y lo que éste decía de la doctrina en general, lo dijo antes que él Vico: "Toda ciudad dividida en partidos por causas de religión ó está ya arruinada ó próxima á perecer"; es el regnum divinum desolabitur de Cristo (Mathei XII 25). Esta es la razón de que, como nota el mismo Vico, "la humanidad en todas partes estableció sus prácticas sobre estos tres sentimientos comunes del género humano $1^{\circ}$ etc... $2^{\circ}$ que // se procuren ciertos hijos de ciertas mujeres con las que tengan comunes por lo menos los principios de una religión civil: porque los hijos se educan por los padres y madres conforme á la religión en que han nacido ... Así que no hubo nunca en el mundo una nación de ateos, pero ni siquiera hubo ninguna en que las mujeres no pasaran á la religión pública de sus maridos." (1)».114

Y cita a continuación Calatayud también a Michelet, «escritor nada sospechoso por cierto», ${ }^{115}$ en pro de la antiliberal tesis de que la pluralidad discuti-

113. Cfr. la entrada correspondiente a «Calatayud Bonmatí, Vicente», en J. Paniagua \& J. PiQueras, Diccionario biográfico de políticos valencianos. 1810-2005, Inst. Alfons el Magnànim, Valencia, 2003.

114. V. Calatayud, Influencia en la prensa periódica, en «Folletín de El Nuevo Alicantino», pp. 85-86; en El Nuevo Alicantino. Propiedad y órgano oficial del Círculo Católico de Obreros. Con censura eclesiástica, a. I, n. 117, Alicante, miércoles 29 de mayo de 1895, pp. 1-2. Notas a pie de páginas del texto citado: En p. 85 del Folletín: «(1) Debats, 15 de Abril de 1831, citado por Taparelli.» En p. 86 del mismo: «(1) Vico, Scientia nova [sic] t. I, pag. 101».

115. $I b$., p. 1; en «Folletín», cit., p. 86. 
dora que está en la esencia del periodismo va sustancialmente en contra de la esencia de la religión, que es la unidad del credo y de los creyentes.

En agosto de 1896, la segunda guerra de Cuba — que había comenzado en febrero del año anterior - se extiende a Filipinas, acercándose ya al notorio Desastre del '98 con la implicación interesada de Estados Unidos en la guerra con España (desde el 18 de abril de 1898 hasta el 10 de diciembre del mismo año con el Tratado de París). Obviamente, estos son temas principales que cubren las páginas de la prensa periódica. Para muestra, un botón; incluso de prensa 'regionalista', destinada prioritariamente a sus "intereses": el Diario Imparcial de la Mañana La Rioja analiza en primera página, de la mano de Moret, las diferentes fases de la participación de Estados Unidos en la insurrección cubana; mientras que en la segunda página, bajo el rótulo de «Correo de Cuba», se acogen diversas columnas de opinión y sueltos sobre el tema de la guerra. En la carta de un «movilizado con el cuerpo de voluntarios de color que mandaba» y miembro del «ejército de operaciones», éste describe en el periódico el cambio en el panorama caribeño desde su perspectiva ahora de soldado y a la vez que anuncia su inédito «Diario de un movilizado» (del que sin duda forman parte ésta y otras cartas publicadas) con mando «al frente de mis 300 leones de los cuales 100 son de caballería». Relata el movilizado, con romántico patriotismo, las vicisitudes de las batallas y la necesidad de hacer tropa española «de estos valientes descendientes del África», mulatos «que tenemos que llamar hijos porque nosotros les dimos religión, idioma y libertad» y que si se vuelven adversarios fieros y valientes lo hacen «por ignorancia, no por odio á España». Insiste en reclamar el autor de la carta que se les explique a esas «500.000 mil almas de Colón» que «nosotros los que formamos la clase media también somos hijos de los que gemían en las ergástulas de Roma y Grecia; que también somos descendientes de esclavos que sus cadenas se rompieron al espirar Jesucristo en el Gólgota», y desde entondes la expansión ecuménica del Evangelio va extendiendo sus raíces, las cuales, sin cesar

«lo invaden todo, y producen frutos en unos paises más tarde y en otros más temprano; y la civilización hay que creer con Vico recorre un círculo fatal, y á esos pobres seres de tostada tez lo que les hace falta es civilizarse para entrar á disfrutar la humana herencia para sentarse al banquete de la vida.» ${ }^{\mathbf{1 1 6}}$

116. [ ], «Carta de Cruces», La Rioja. Diario Imparcial de la Mañana, a. VIII, n. 2.209, Logroño, miércoles 22 de abril de 1896, p. 2 cc. 1-2; citas a c. 2. 
Medidas de asimilación racial y de integración social defendidas por el General Pando, jefe del segundo cuerpo del ejército al que pertenece el anónimo corresponsal y defensor de las tesis de su comandante.

En un lunes 25 de enero de 1897 las páginas segunda y tercera de $E l$ Noticiero Tarraconense (1896-1897) ilustraban la tarde con noticias (tomadas del Correo de Madrid del día anterior) acerca de los eventos de la campaña bélica. Entre telegramas y partes de guerra en Cuba y Filipinas y con los americanos del norte inmiscuidos, se halla una frágil columna dedicada a Vico, la filosofía de la historia y la situación actual española. El artículo lo firma «S.», y viene reproducido - reimpreso dentro de las dos citadas páginas idénticas con el anterior - al día siguiente en El Correo de Gerona (1893-¿1899?). Tiene por título «Filosofía de la Historia». ${ }^{117}$ El siguiente interesante texto, fluente desde el ya referido Correo de Madrid del domingo antes hasta desembocar en la sección siamesa «El Dominical» de los recién citados diarios catalanes, y que transcribimos a continuación, da cuenta de la aplicación de la doctrina de Vico al análisis de la historia viviente de la decadencia española, abocada en estos momentos a la pérdida de sus últimas colonias ultramarinas:

«Conocida es la hipótesis del filósofo napolitano Vico, según el cual las naciones, como los individuos, nacen, crecen, decaen, mueren y desaparecen. Si no es exacta esta teoría en toda su a[m]plitud, tiene ciertamente un fondo de verdad que, por desagradable que sea confesarlo, puede aplicarse á nuestra patria.

Echando una ojeada sobre la totalidad de su historia, vemos efectivamente que nació, o renació si se quiere, después de la rota del Guadalete; creció sucesivamente durante los siglos de la Reconquista, hasta llegar á su apogeo en el reinado de Carlos V, en cuyo imperio no se ponía el sol, y empieza luego la decadencia, que va pasando por todos los reyes de la casa de Austria, sigue; á duras penas contenida con la de Borbón hasta que no le quedan á España de sus inmensos dominios más que algunas islas en el remoto Oriente y en el golfo de Méjico.

117. "S"., «Filosofía de la Historia», El Noticiero Tarraconense. Diario independiente de la tarde, a. II, n. 48, Tarragona, 25 de enero de 1897, p. 2 c. 4 y p. 3 c. 1. Ibidem en El Correo de Gerona. Diario de la tarde de avisos y noticias, a. V, n. 20, Gerona, martes 26 de enero de 1897, p. 2 c. 4 y p. 3 c. 1. Diario de efímera vida, como sucedía a otros de salida vespertina, El Noticiero Tarraconense se mantuvo saliendo por un periodo de tres meses (del 5 de diciembre al 28 de febrero). 
Al llegar aquí, despnés [después] de tan rápida excursión histórica, es natural preguntarnos: ¿hemos terminado el período de nuestra decadencia y vamos á subir de nuevo por la montaña de la gloria, como Sísifo en su labor horrenda, á empezar un nuevo día, como el astro después de sus tristes ocasos, ó hemos de pensar que las decadencias de los pueblos son definitivas y sin esperanza de redención?

Ateniéndonos á los hechos que presen//ciamos en este momento, habría lugar á deducir que estamos descendiendo aún en la pendiente que empezó con Felipe III y que no hemos cesado casi de recorrer. Los dos restos que nos quedaban de la basta herencia legada por nuestros ancestros antepasados, se hallan tan comprometidos, que es muy de temer tengan la misma suerte que las demás posesiones europeas y americanas perdidas por nosotros para siempre. Podremos desarmar hoy la rebeldía levantada en armas contra España, pero el fuego de la venganza y odio que ha de quedar bajo las cenizas y puede producir más terribles incendios, éste no será fácil apagarlo; y mientras subsista, nos recordará la funesta trayectoria que hace siglos venimos recorriendo enmedio [sic] de la vida universal.

Lo que procede ahora meditar es si la ley de Vico es una ley mecánica, fatal, irresistible como las leyes del mundo físico; ó si la voluntad humana puede reaccionar y emanciparse de ella, rompiendo sus férreas líneas y convirtiendo en alardes de fuerza los anuncios de forzada decadencia y los augurios de muerte en gloriosa resurrección. Las naciones no mueren si no quieren morir; no decaen si no quieren decaer. Las enfermedades y accidentes, que son inevitables en los organismos individuales, no alcanzan á los colectivos cuando éstos los resisten con decidida voluntad.

En prueba de ello, ahí está Francia que, habiendo tocado las supremas alturas con Carlo Magno, volvió á subir á ellas con Luis XIV y últimamente con Napoleón; Italia ha sido repetidas veces árbitro del Mediterráneo con Roma, con Venecia, Florencia ó Pisa. Se dan excepciones á la regla general. ¿Por qué no habría de ser una de ellas nuestra patria?

Las naciones son grandes o pequeñas, no por su extensión ó por el número de sus habitantes, sino por la idea que brilla en su frente, por el calor que encierran en su corazón.

Ahí está el secreto de su decadencia ó su grandeza. Cuando la antigua Roma se aferró á una religión muerta y la corrupción gangrenó sus entrañas - [f]ué consiguiente que perdiera la hegemonía del mundo. Los grandes siglos para cada nación son aquellos en que han albergado respectivamente una ardiente fé en una idea y la han cultivado con inteligencia y amor; como la Alemania moderna la ciencia; 
la Francia de ayer la libertad; la España del siglo de oro la religión. Es cierto que los ideales cambian, se transforman, evolucionan; pero lo importante es tenerlos, pues en este caso las naciones se levantan y emprenden otra vez la marcha progresiva, á pesar de todas las leyes de la historia y de los círculos dantescos del filósofo napolitano.

¿Se siente España capaz de recobrar una fé ardiente en algo transcendental? En este caso está salvada.

$$
\text { S.»118 }
$$

Pocos artículos se hallarán en la prensa española por estas décadas, desde aquellos once dedicados a Vico por Juan Donoso Cortés a mitad del siglo, que se centren en la doctrina viquiana vinculada indeleblemente a la moderna y aplicada - social e históricamente- disciplina de la Filosofía de la Historia; y que, además, sea utilizada como clave hermenéutica del devenir histórico de la nación española, rodando en su acelerada cuesta abajo hacia la consumación de la crisis de fin de siglo representada en el Desastre del '98, acontecimiento tan impactante en la conciencia nacional como para dar lugar y nombre a una Generación de filósofos, literatos, poetas, artistas e intelectuales, destacable de entre las más representativas e importantes de la historia española moderna y contemporánea.

Durante el mismo año de 1897 continúa la presencia de Vico emergente en la prensa política, tanto en la conservadora, tradicionalista y católica, como en la prensa liberal, demócrata y progresista. Así, dentro de la órbita más conservadora del canovismo, la primera columna de la portada del número correspondiente al sábado 13 de marzo de La Unión Católica (18871899), dirigido por Juan Menéndez Pidal, ${ }^{119}$ abre con una referencia a Vico, bien que disconforme, al inicio del alegato editorial sobre las condiciones de «general en jefe» que el Gobierno ha de tener en cuenta en su política sobre las guerras coloniales en activo. Se lee en esa primera plana:

«La historia, que con frecuencia presenta las mismas vicisitudes una y otra vez repetidas, no es precisamente lo que decía Vico, la copia

118. Ibid. (p. 2 c. 4 // p. 3 c. 1). No hemos logrado ejemplar para confrontar el Correo de Madrid de domingo 24 de enero de 1897; ni descubierto el nombre del autor bajo la sigla «S.».

119. Juan Menéndez Pidal (1858-1915), jurista y académico, hermano mayor del conocido historiador y filólogo Ramón (1869-1968) y del pintor Luis (1861-1932); sobrinos del político Alejandro Pidal y Mon (1846-1913), fundador del partido Unión Católica. 
de los siglos pasados por el actual; pero tampoco la sucesión de espectáculos que no tengan algún parecido. La guerra ha cambiado mucho con la diferencia de las armas, de la táctica y aun de la política, y no seremos quien lo niegue; pero no es menos cierto que también ofrece circunstancias muy análogas al través de los siglos. Y en lo que se refiere á las condiciones de los generales que han de mandar en jefe las expediciones, se observa que, á pesar de aquella diferencia de medios, es bastante grande la analogía en los distintos períodos históricos.»1 ${ }^{\mathbf{1 2 0}}$

Al día siguiente, el domingo 14 de marzo Vico vuelve a aparecer, ahora en la conferencia inaugural — depuesta en el Salón de Recreo de la capital de Burgos - de una serie anunciada por su autor, el cronista, bibliográfo y archivero Anselmo Salvá (1849-1922), sobre «los reyes burgaleses», que, como charla introductoria a las futuras, versó sobre el concepto general de historia; con gran aceptación por parte del público asistente, al parecer, según reseña al día siguiente el conservador-católico independiente Diario de Burgos, de avisos y noticias (1891-e.p.):

«Después de un elocuente exordio, en que recordó el señor Salvá las glorias castellanas y las burgalesas en especial, examinó el punto tan discutido de si la historia es ó no una ciencia, y analizó las diversas doctrinas filosóficas sustentadas por Bossuet, Vico y otros autores, cuyas conclusiones discutió dentro de la más pura ortodoxia, que informó la conferencia en todas sus partes. [...] escuchó al final una entusiasta ovación.»> ${ }^{\mathbf{1 2 1}}$

Un mes antes de la conferencia de Salvá, el diario de Salamanca $L a$ Información (1892-1897), salido de los tipos de la Imprenta Católica Salmanticense, daba noticia de otra conferencia impartida en la Academia de Santo Tomás de Aquino, y en la que había sido tratado Vico. La disertación sobre la Filosofía de la Historia estuvo a cargo del joven académico y «aventajado alumno de la Facultad de Derecho» Eusebio Díaz González (1878-1968). ${ }^{122}$

120. I. DEM., «Las dotes de un general en jefe», La Unión Católica. Diario religioso, político y literario, a. XI, n. 2.904, Madrid, sábado 13 de marzo de 1897, p. 1, cita en c. 1. Curiosamente, dos referencias sobre Vico coinciden en prensa en el mismo día (cfr. infra cita Heraldo de Teruel).

121. [ ], «En el salón.», Diario de Burgos de avisos y noticias. Últimos telegramas y noticias de la tarde, a. VII, n. 1.840, Burgos, lunes 15 de marzo de 1897, p. 2 c. 3.

122. Así anunciaba El Lábaro. Diario independiente de Salamanca, el 30 de abril de 1897, la integración 
Según la crónica local:

«Con facilidad de expresión y elegante palabra desarrolló el señor Díaz el concepto de dicta [dicha] materia exponiendo que el hombre se desenvuelve libremente pero baja [bajo] la acción de la presidencia, pasando luego á desarrollar algunos sistemas ideales sobre dicho asunto deteniéndose principalmente en los de Vico, Hergel [sic] y Herder, citando aunque brevemente á de Maistres y de Bornald [sic] á lo[s] que refutó valientemente, y terminó con el de San Agustín con el cual estaba conforme y anunciando continuar el tema en la sesión inmediata.

Hicieron objeciones de los señores Peña Doreste, Amador Eley, Andrés y Campoamor.»123

No deja de resultar una curiosidad, casi anecdótica si se quiere, que a finales del año siguiente, en plena experiencia del Desastre, El Eco de Santiago (1896-1938) ${ }^{\mathbf{1 2 4}}$ se haga eco de otra conferencia en la misma línea catolicista de la antes citada. En esta ocasión, a pesar de que la reseñada disertación del catedrático Leandro María Silván, ${ }^{125}$ impartida en el Ateneo León XIII de la capital gallega el lunes 14 de noviembre, trataba sobre el

de Díaz en el consejo de redacción del periódico. E. Díaz González fue profesor auxiliar de Derecho hasta tomar posesión como Catedrático de Derecho Romano de la Universidad de Barcelona, de la que fue rector entre 1927 y 1930 bajo la dictadura de Primo de Rivera. Huyó de Cataluña en agosto de 1936, tras haber sido cesado por el gobierno de la Generalidad por su señalamiento «españolista» bajo su rectorado; fue posteriormente depurado y rehabilitado por el gobierno franquista en 1939 dada su significada militancia política de derechas. Cfr. Diccionario de catedráticos españoles de Derecho (18471943) [en línea], Universidad Carlos III de Madrid - Instituto Figuerola de Historia y Ciencias Sociales: http://www.uc3m.es/diccionariodecatedraticos

123. [ ], Noticias Locales en La Información. Diario de Salamanca, a. VI, n. 1.349, martes 9 de febrero de 1897, p. 3 c. 2. Periódico definido como «integrista» dentro de la prensa católica salmantina, en la línea continuada por Manuel Sánchez Asensio antes en La Región (1890-1892). Cfr. JEAN-Claude Rabaté, 1900 en Salamanca. Guerra y paz en la Salamanca del joven Unamuno, Ed. Universidad de Salamanca, Salamanca, 1997, p. 11 del Prólogo de J.A. PAscual y p. 14 de la Introducción del hispanista francés (quien aconseja para más información el libro a cargo de Teresa SANTANDER, Publicaciones periódicas Salmantinas existentes en la Biblioteca Universitaria (1793-1981), Salamanca, 1986).

124. Diario católico-conservador dirigido inicialmente por Maximino Rodríguez Regalado, pero ya en el año y número referido por nosotros la dirección recaía sobre su nuevo propietario, Celestino Sánchez Rivera (1870-1948). Se pone fecha de finalización 1938, aunque continuó su actividad ya que, tras haber apoyado el golpe militar franquista, en ese mismo año cesó su edición para fusionarse en octubre con El Correo Gallego (cfr. nótula en Diccionario da literatura galega, II, «Publicación periódicas», Dolores Vilavedra, coord. del vol., Ed. Galaxia, Vigo, 1997, pp. 161-162).

125. Leandro M. Silván de la Iglesia ( 11874 ? - †1918), en 1884 era catedrático del Instituto Libre de segunda Enseñanza de Ponferrada (León) desde que tomó posesión de su cátedra de Latín y Castellano en octubre de 1870. Según los registros, en 1893 figura de catedrático en el Instituto de Santiago de Compostela (también sigue en 1909), donde había realizado la permuta de su plaza por concurso en Zamora. 
tema de «Gramática general», no falta ocasión ni motivo para que el recensor «B.» incida en la crítica a la originalidad de la ciencia de Vico. ${ }^{\mathbf{1 2 6}}$ Así, al relatar el comienzo de la conferencia, en la que el orador trata de definir «la "Gramática general" llamada por otros "Filosofía del lenguaje"»:

«Negó que esta importante ciencia fuese tan reciente como muchos han creido y á tal fin recordó lo que Vico decía apropósito [sic] de la filosofía de la historia, creyéndola ciencia nueva cuando ya San Agustín en la "Ciudad de Dios" en el siglo IV Paulo Orosio y otros sabios, habían escrito páginas sublimes sobre filosofía de la historia.»” ${ }^{\mathbf{1 2 7}}$

En septiembre de 1897, al hacer «Balance del siglo XIX» el redactor de El Movimiento Católico (1889-1897), Antonio Balbín (1842-1919), recuerda en página de portada del diario madrileño - bajo la dirección propontificia y proeclesiástica de Valentín Gómez - cómo España, en consonancia con el 'occidente' europeo se encuentra en ese momento inmersa en un curso modificacional de decadencia y barbarie:

«Se han vuelto á oir voces fatídicas del fin del mundo, y ha tardado mucho en comprenderse que nos hallamos en una de las que llamaba el filósofo napolitano Vico transformaciones ó círculos de la historia. A principio del siglo se resistían los jurisconsultos á escribir Códigos; al terminar aparecen por todas partes, como los hongos.

Las naciones nuevas en Europa todas son débiles, y las antiguas se nos presentan gastadas. ¿Será así como comienzan los continentes á deponer el cetro que antes llevaban, la hegemonía reconocida por los demás y su representación preponderante en la historia? Detrás de Europa está América, detrás de América Africa. El Asia ya tuvo su parte de sol y de calor mucho tiempo antes de que se inaugurase la Era cristiana.

Los pueblos no se conservan ni se restauran sólo por la ciencia, ni por la preponderancia internacional, ni siquiera por el trabajo. La Religión y la moralidad son las únicas que causan esa revolución bienhadada. ${ }^{\mathbf{1 2 8}}$

126. B., «En el Ateneo León XIII», El Eco de Santiago. Diario de Compostela, a. III, n. 721, Santiago de Compostela, martes 15 de noviembre de 1898, p. 3, cc. 1-2.

127. $I b$., c. 1 .

128. A. Balbín, «Balance del siglo XIX» (II), El Movimiento Católico, Fundado por el Primer Congreso Católico Español, a. X, n. 2.639, Madrid, miércoles 1 de septiembre de 1897, p. 1 cc 1-4; cita cc. 1-2. Antonio Balbín de Unquera (1842-1919), asturiano doctorado en Leyes y Teología; ganó por oposición la plaza de consejero de Estado a los veintidós años, y luego secretario general; académico, profesor 
Además de la referencia directa a la doctrina viquiana de las edades, expresada en el concepto más genérico de «transformaciones» históricas, Balbín hace uso de la tesis de la Scienza nuova sobre la religión como principio de civilidad humana, no sólo al origen de la humanidad sino también en la vuelta que sufren las naciones a la simplicidad de los principios, una vez se disuelven en la decadente «barbarie della riflessione».

Desde la orilla liberal y progresista, un estudio sobre heráldica turolense, a cargo del intelectual republicano, profesor en el Instituto de Segunda Enseñanza de Teruel y activista cultural regeneracionista, Federico Andrés y Tornero (1866-1913), resulta publicado en el sabatino regional ilustrado Heraldo de Teruel (1896-1897). Este artículo de Andrés apoya en la Scienza nuova su tesis de que «los escudos de armas de los pueblos constituyen una de las guías más importantes para hacer su historia». De tal modo, al inicio del texto ya podemos leer lo siguiente:

«Son los blasones que los pueblos ostentan en sus escudos, la representación de los rasgos más salientes de la historia de cada uno de ellos, traducidos generalmente en actos heróicos, realizados casi siempre en el principio de su existencia, actos que unas veces llegan á nosotros desfigurados por las exageraciones que en sí va acogiendo la tradición, y otras apoyados en documentos de valor para la crítica, ciencia por cuyo tamíz tienen que pasar las fuentes de todos los sucesos que la Historia registra en sus anales, dado el nuevo modo de ser que los historiadores han

\footnotetext{
auxiliar de Derecho en la Universidad Central de Madrid y reconocido políglota y traductor. Ejerció también el periodismo, como director de la revista Asturias y colaborador de numerosos periódicos, entre ellos, asiduamente, de la prensa malayesa La Opinión de Villaviciosa (1893-1898) y La Voz de Villaviciosa (1906-1913). Miembro de la Academia de Ciencias Morales y Políticas; de la Asociación de Legislación Comparada (París); y de la Unión Iberoamericana de Madrid, muy vinculado con la emigración; y miembro de la Academia de Arqueología y Geografía Central de España y sus Colonias. Fundador y presidente del Centro Asturiano de Madrid. El Movimiento Católico, diario vaticanista y «posibilista» (proconvivencia entre Iglesia y Liberalismo), seguidor de las directrices de León XIII, se posicionó vehementemente durante el conflicto bélico del Rif (1893-1894) y luego en contra de Estados Unidos por su apoyo a los rebeldes en Cuba. El director del periódico, el conocido tradicionalista Valentín Gómez, fundó junto con Alejandro Pidal y Mon la Union Católica (1876). El diario se despidió de sus lectores al mes siguiente del aquí citado, incapaz de aglutinar todas las tendencias y facciones políticas del catolicismo en España a finales del siglo.
} 
impreso á esta rama del saber, desde que Vico, el famoso autor de la Ciencia nueva, nos hizo comprender que más que a batallas, casamientos y parentescos de reyes deben estudiarse las causas de los hechos y la manera de ser de las generaciones que nos han precedido.»129

Este artículo publicado en el órgano del Ateneo Turolense (una asociación de carácter regeneracionista, 1890), de la mano del Secretario del mismo y a la par fundador y director del Heraldo, ${ }^{130}$ nos ofrece una importante recepción de la obra del napolitano ya no sólo en clave popular de «filosofía de la historia», sino de ciencia histórica misma y de disciplinas historiográficas concretas.

También en la señalada línea liberal, republicana y progresista, El País (1887-1921) esgrime en primera plana - siguiendo la costumbre de los periódicos «de partido» de dejar en primera además del editorial y los sueltos de redacción también las noticias relacionadas con la formación política representada y defendida - el argumento de que de un país con un estado político y social, un estado cultural, y un estado de civilización y progreso tan desoladores como España, «tierra en lamentable atraso, donde lo único que brilla es el circuito establécido en torno de los reyes» y en la que «Cánovas conserva las mazmorras y el tormento», bien podría decirse, «haciendo buena, tal vez sin conocerla, la teoría de Vico, el gran italiano»,

129. F. ANDrés, «Las armas de Teruel», Heraldo de Teruel. Semanario regional, ilustrado, de noticias, literatura, ciencias é intereses morales y materiales de la provincia, a. II, n. 24, Teruel 13 de marzo de 1897, pp. 2-4; cita en p. 2. Federico de Andrés y Tornero, regionalista de ideología republicana que se amoldará primeramente al posibilismo y más tarde al fusionismo, llegó a ser alcalde de su ciudad y diputado. Está reconocido como un prestigioso investigador de la historia de Teruel. El semanario ilustrado turolense tuvo de vida un año, de octubre de 1896 al siguiente.

130. «Federico Andrés, profesor auxiliar de Psicología, Lógica y Ética que redactó una historia de la Literatura turolense por entregas, así como una recopilación de leyendas de Teruel, la mayoría de origen medieval. A finales del siglo fundaría y dirigiría el periódico Heraldo de Teruel, a través del que entraría en contacto con varios regeneracionistas del Bajo Aragón para debatir los males que afectaban a la provincia. A finales de 1892 asumirá el cargo de secretario general de El Ateneo junto a Pascual Serrano que era el presidente.» José Serafín Aldecoa Calvo, «Los inicios de la Segunda Enseñanza en Teruel: el Instituto Provincial en el siglo XIX (1845-1900)», en Guillermo VicENTE y Guerrero (CoOrd.), Historia de la Enseñanza Media en Aragón (Actas del I Congreso, Zaragoza, 2009), Institución Fernando El Católico, Diputación de Zaragoza, 2011, pp. 169-198; cita p. 194. Sobre Andrés véase la reseña biobibliográfica publicada por el profesor de IES e historiador S. ALDECOA CALVO, «Federico Andrés y Tornero», A tres bandas, n. 35, Teruel, febrero 2011-febrero 2012, p. 73. 
que este «país perdido es un país bueno para ser conquistado» por otra nación con intenciones expansionistas y coloniales. ${ }^{131}$

Como en el caso anterior, igualmente un nuevo autor firma con sus iniciales su «Conclusión» en la sección de Revista Internacional del diario fusionista El Liberal (1886-1887), órgano del Partido Liberal de la provincia de Alicante, en el número del jueves 5 de agosto, es decir, tres días antes del magnicidio de Cánovas del Castillo bajo las balas de un anarquista italiano. El final del artículo, centrado en Estados Unidos de Norteamérica, iniciado en la entrega del día anterior, lo dedica "E.M." a la «vanidad» — de las personas y de los pueblos (lo que nos recuerda a las viquianas concepciones de «boria dei dotti» y «boria delle nazioni») — que de manera evidente alcanza a grandes colectividades humanas, una de entre las cuales, Estados Unidos de Norteamérica, que destaca por ser «un ejemplo tan raro como notable de prodigiosa velocidad en su desarrollo y crecimiento», constituye la diana de los dardos de "E.M." En especial porque, creyéndose aquélla «superior á todas las demás naciones, invencible, segura, más fuerte y poderosa», también se cree exenta de las obligaciones de la cortesía y de la diplomacia, y eximida de cualquier consideración y formalidad internacional para con aquellos países a «los que mira como inferiores, equivocándose acaso por los ímpetus de su vanidad nacional». ${ }^{132}$ En este contexto de crítica a la «hiperbólica» y arrogante «vanidad nacional de esa república» ante el «colosal [...] desprecio que le inspiran todas las demás naciones», ${ }^{133} \mathrm{y}$ de crítica enmarcada en las circunstancias de búsqueda europea de un tratado de paz que ponga fin a la contienda bélica entre España y Estado Unidos, es significativo que la disertación periodística tenga comienzo con la

131. E.L., «Para su alteza», El País. Diario Republicano Progresista, a. XI, n. 3.656, Madrid, jueves 8 de julio de 1897, p. 1 c. 3-4; cita c. 4. Se trata de una crítica «Croniquita» — en la sección «Cosas del Mundo»- a propósito de la visita del príncipe japonés Arisugawa. Las siglas del autor bien podrían corresponder — aventuramos una suposición - al redactor del periódico Ernesto López Fernández (1867-1923), gaditano conocido en los periódicos de la corte por el pseudónimo de «Claudio Frollo». El periódico El País era el órgano de expresión del Partido Republicano Progresista (de Manuel Ruiz Zorrilla y Nicolás Salmerón), acción en la que tomó el relevo del espacio oficial dejado por El Progreso desde su suspensión por las autoridades autoritarias. La misma que sufrió El País el 18 de agosto de 1898 después de dos años y medio de acoso político por la fiscalía de imprenta, con encarcelamiento de redactores y del editor que figuraba de responsable del periódico (cfr. la nótula descriptiva en la ficha del periódico en la HD de la BNE).

132. E.M., «Revista Internacional. (Conclusión)», El Liberal. Diario político y de intereses materiales. Órgano del Partido Liberal de esta provincia, a. XII, n. 3.376, Alicante, jueves 5 de agosto de 1897, p. 3 cc. 1-2; cita c. 1.

133. $I b$., c. 2. 
rememoración de la obra de Vico y su «talento extraordinario». Arranca escribiendo "E.M." el argumento que vertebra toda la columna:

«Hay un libro notabilísimo, ya casi olvidado, que se titula la Scienza nuova, escrito por Juan B. Vico, de una profundidad, de una erudición y de un talento extraordinario, en el cual, con pruebas numerosas históricas, se señala la poderosa influencia que la vanidad nacional ha ejercido en todos tiempos en la suerte de los Estados y en la humanidad entera. El amor propio exagerado es, en efecto, la pasión más general, la más predominante, la más multiforme de nuestra especie, y su desarrollo y manifestaciones muy comunmente desapercibidas, constituyen el núcleo ó materia principal, casi esclusiva, de las obras de los grandes moralistas ú observadores del corazon humano, como Montaigne, La Rochefoucauld, Vaurenargues y otros.

Los estragos de esa vanidad se notan sobre todo en las personas que por cualquier causa se levantan mucho sobre las demás, y en los pueblos que, á semejanza de aquéllas, adquieren con rapidez poder y riquezas. [...]»» ${ }^{134}$

\section{Del Desastre del '98 al final de la Restauración (1902). Como «un háli- to del sepulcro».}

Recién finalizada la Gran Depresión del '73 que marcó el devenir económico europeo (1873-1896), acontece 1898 como uno de los años determinantes en la conciencia trágica del pueblo español y, desde luego, cifra paradigmática en la historia de España. En abril se produce la guerra con Estados Unidos; en julio acaece el irremediable desastre de Santiago de Cuba; y en diciembre el tratado de finalización de la guerra entre España y Norteamérica. La gran crisis española representada en el '98, no lo es tanto económica como sí de crisis de valores, de conciencia identitaria (el tan debatido "problema" de España; la definición de Europa; los nacionalismos; el nuevo imperialismo norteamericano; afán emancipatorio; etc.), de "rebelión de las masas", de creencias en el individuo, y de hundimiento de la arquitectura social de la clase media y de los ideales de una pequeña burguesía (que en España nunca hubiera una revolución burguesa, como tampoco existió una reforma agraria, son dos elementos básicos para comprender esa 'frustración' fini-

134. Ib., c. 1 . 
secular, sea pequeñoburguesa por un lado — mostrada en el regeneracionismo-, sea obrera-jornalera por otro - evidenciada en las movilizaciones revolucionarias del proletariado- - ). Mas, tal y como se presenta, la denominada «crisis de fin de siglo» en España está ubicada en el vórtice del tornado histórico que constituye la más general crisis europea de fin de siècle; y que, en lo referente a política internacional, desde 1895 va centrifugándose como una crisis mundial ya no estrictamente eurocentrista sino expansionista de influencia estadounidense en todo el completo escenario mundial. España encadena acontecimientos bélicos que entintan las páginas de la prensa, desde la segunda guerra del Rif (1893) a la guerra de Cuba (1895), y de ésta a la guerra contra la insurrección independentista tagala en el archipiélago de las Filipinas apoyada por Estados Unidos (1896). De ahí directamente a la confrontación entre España y Estados Unidos a finales de 1897, justo cuando España preparaba una autonomía política para Cuba y firmaba un pacto con el independentismo filipino, mientras que los americanos intervenían pro domo sua en la guerra cubana. El intervencionismo bélico exterior que caracterizará la política mundial estadounidense se evidencia, precisamente, en el conflicto hispano-norteamericano en 1898, al declararse tutelar de la recién proclamada independiente república de Cuba, y con su paso al dominio colonial de las otras provincias españolas de Puerto Rico (hasta hoy) y de Filipinas (esta última, a principios de 1899 comenzará su guerra independentista frente a los EEUU durante tres años). Suele decirse que ante el conflicto generalizado a finales de siglo entre países europeos y colonias ultramarinas, el gobierno español optó por la derrota militar en el exterior antes que arriesgarse a una revolución interior que pusiera en peligro a la monarquía. El tratado parisino de 10 de diciembre de 1898 programó la independencia de Cuba, así como la cesión del dominio y la tutela a EEUU de Filipinas, Guam y Puerto Rico. Con la venta a Alemania, al siguiente año, de las últimas colonias españolas en Oceanía, España asistió al final de su imperio colonial y al comienzo de un evidente imperialismo norteamericano, iniciado externamente en el Caribe, que habrá de marcar el cambio de brújula de las relaciones internacionales en el siglo XX tanto como las aspiraciones emancipadoras de antiguas colonias europeas, ahora intervenidas por la nueva potencia emergente.

Como también es sabido, a la conciencia española de decadencia y pérdida se unió, paradójicamente, la movilización sociopolítica del regeneracionismo (cuya exponencia recae en Joaquín Costa) frente al caduco canovismo; el positivismo burgués asumido por el krausismo (y en este ámbito la reubicación de la Filosofía de la Historia metamorfoseada en "ciencia social"); y el activismo inte- 
lectual y literario-filosófico de la Generación del '98 (representada en la figura de Miguel de Unamuno y la filosofia de la novela, también con Valle-Inclán, Baroja, “Azorín”, A. Machado et alii), ${ }^{135}$ con fuerte apertura hacia las corrientes existencialistas y las filosofías de la vida. En el ámbito de la política nacional se asiste a la recta final de la época de la Restauración. Aceleran esta cuesta abajo de la monarquía y de transformación histórica el asesinato de Cánovas del Castillo, gran muñidor y garante de la política oligarquica de gobiernos alternantes en la Restauración, y los atentados terroristas y magnicidios; la emergencia del anarquismo ibérico; el auge del asociacionismo obrero; la organización política y sindical del socialismo; el peso del regionalismo y los conflictos autonomistas e independentistas; el afán de unionismo católico; el avance republicano, insustancial en las elecciones legistativas por sí a partir de de las municipales de 1892; ... $\mathrm{y}$, por supuesto, el final de la alternancia bipartidista de gobiernos (cambiando para que todo permanciese igual) hasta que bajo el gobierno presidido por Sagasta acontezca ejecutivamente el reinado de Alfonso XIII tras su mayoría de edad el 17 de mayo de $1902 .{ }^{136}$

De «dos actitudes opuestas» habla Antonio María Poveda (1880-¿?) en sus «Impresiones», de febrero de 1898, recogidas por El Cantábrico (18951919/1937), diario regional republicano democrático e independiente y de tendencia progresista, regeneracionista y laica, dirigido por José Estrañi y Grau. Poveda ejemplifica la 'frustración' noventayochista refiriéndose a quienes antaño «destruyeron teorías inútiles y en su lugar pusieron la enseña de la fraternidad y de la igualdad»y que ahora «son los primeros que se ensañan con seres indefensos». ${ }^{137}$ Rememora el tiempo en que vencieron las nuevas ideas y con ello «per-

135. Algunos recientes replanteamientos en: José LuIS MORA GARcía, «El valor filosófico de la literatura del 98», en Filosofia Hispánica Contemporánea: el 98. Actas del XI Seminario de $\mathrm{H}^{\mathrm{a}}$ de la Filosofía española e iberoamericana (USAL, septiembre de 1998); ID., «La generación del 98. Entre literatura y filosofia», en Miguel de Unamuno, estudio sobre su obra, IV (Actas VII Jornadas unamunianas) Casa-Museo, Salamanca, A. Chaguaceda (Coord.), 2009, pp. 421-431; Francisco José Martín (Ed.), Las novelas de 1902, Biblioteca Nueva, Madrid, 2003 (vid. «Filosofía y novela», en pp. 183-193); MARía RodRíGUEz GarCíA, Filosofia y novela. De la generación del 98 a José Ortega y Gasset, Athenaica Ediciones, Sevilla, 2018.

136. Véase Historia de España, dirigida por M. Tuñón de Lara: VIII Revolución burguesa, oligarquía y constitucionalismo (1834-1923), en especial Tercera Parte «La época de la Restauración: panorama político-social, 1875-1902», a cargo de José Luis García Delgado, con introd. (1900-1913) por M. Tuñón de Lara.

137. A.M. PovedA, «Dos actitudes opuestas», El Cantábrico. Diario de la mañana, a. IV, n. 1.013, Santander, miércoles 2 de febrero de 1898, p. 1 c. 5 y p. 2 c. 1; cita p. 2 c. 1. A.M. Poveda Sánchez es autor de El Derecho en la vida. Estudio-Memoria leído en los ejercicios del Grado de Doctor (L.G. de Victoriano Suárez, Madrid,1903). En 1905 fue nombrado juez de primera instancia en el partido de Cangas de Onís. 
diéronse para siempre en el olvido de los pasados tiempos las diferencias existentes y que hacían enemigos á los hombres que en escuelas opuestas profesaban». ${ }^{138} \mathrm{Y}$ así reflexiona Poveda viquianamente sobre el ideal de humanidad (por decirlo con guiño al título de la versión krausista del titulado por Julián Sanz del Río):

«El ideal de nuestra época se iba realizando; las más opuestas ideas se respetaban en el palenque de la lucha científica, y los que un día fueron considerados como ilusos y utopistas veíanse hoy en posesión de la verdad por demostraciones miles comprobada. Y con proceder contrario de sus enemigos de antes, respetaban teorías opuestas sin recordar para nada tiempos de opresión con derramamiento de sangre y procesos calumniosos mezclados que, de renovarse según la antigua teoría de Vico, sólo producirían un retroceso á épocas de no dudoso salvajismo.

¿Cómo, pues, no ha de causar extrañeza que sin excusa alguna se dé en los actuales tiempos una de las más incomprensibles aberraciones de la libertad?»139

Podría parecer que a Poveda le contestase Francisco Fernández Villegas (1856-1916), oculto bajo su pseudónimo de "Zeda", ${ }^{140}$ desde la primera de La Época (1849-1936) con motivo de zarandear las vergüenzas de los periodistas norteamericanos avaros de ganancias a costa de la guerra hispano-americana. De hecho, ya el inicio de la crónica contemporánea de Fernández Villegas tiene lugar así de contundente:

«Los periódicos yankees han experimentado una gran decepción. Hicieron cuanto les fué posible para que estallase la guerra entre España y los Estados Unidos, propalaron mentiras, excitaron las pasiones y consiguieron, finalmente, empujar á Mac-Kinley á que cometiera la brutal iniquidad, cuyos resultados han de ser forzosamente duelos y quebrantos.

138. $I b .$, p. 1 c. 5 .

139. $I b$.

140. Periodista y crítico literario y teatral en El Imparcial y en La Época, en los que firmaba con la inicial «Z.» y conocido por el pseudónimo de "Zeda”, Fernández Villegas era colaborador de semanarios, revistas y otras publicaciones como La Ilustración Artística, La Ilustración Española y Americana, Nuevo Mundo, La España Moderna, La Lectura, Hojas Selectas, El Teatro y Nuestro Tiempo (cfr. M. Ossorio y Bernard, Ensayo de un catálogo de periodistas españoles del siglo XIX, cit., pp. 136 y 487). 
Empezó la guerra, y los periodistas de la gran República lanzaron alaridos de júbilo. [...] Si los buitres tuvieran periódicos, clamarían por la guerra. [...]

La guerra, por esta vez, no es para los diarios norteamericanos un negocio pingüe, y como no lo es, el entusiasmo bélico ha decaído.»141

Y, reflejo de la mella que hace en él la dentellada noventayochentista de esa mordida cruel llamada crisis de fin de siglo, el dramaturgo, novelista y periodista español finaliza escribiendo:

«La verdad es que la bestia humana no ha perdido todavía sus instintos: en diplomacia rige el vae victis, en la sociedad el auri sacra fames $y$ en todas partes los instintos de crueldad que reinaban entre nuestros apreciables antepasados de la edad de piedra.

Estas cosas dan la razón al gran filósofo napolitano Vico. "La historia moderna no es más que la repetición de la historia antigua." $\gg{ }^{\mathbf{1 4 2}}$

"Repetición", que es concepto también fluyente de la pluma ilustre de Emilia Pardo Bazán (1851-1921) cuando pensando en Vico la escritora evoca imágenes de círculos y de serpientes mordiéndose la cola. Y lo hace a propósito de las insistencias del carlismo, que le hacen parecer que España no hubiera avanzado en años y en cambio se retrocediese en la historia, como en un déjà vu persistente: «No nos encontramos en el de 1898, sino en el de 1873; no ha sucedido, ¡qué alegría!, nada de lo que deploramos; son un mal sueño la guerra norteamericana y la pérdida de nuestras últimas colonias...», escribe con ironía. ${ }^{\mathbf{1 4 3}}$ Por eso, si bien comienza su artículo la escritora gallega evocando a Vico ${ }^{144}$ como en un recurso literario, en cambio en la parte central del texto la doctrina viquiana aparece ya aplicada a la interpretación de la vida histórica española. Escribe Pardo Bazán al inicio de la columna, con inteligente cinismo:

«El anuncio de que los carlistas van á echarse al monte otra vez, me ha recordado aquella famosa serpiente que se muerde la cola, símbo-

141. ZEDA, «La prensa y la guerra», La Época. Últimos telegramas y noticias de la tarde, a. L, n. 17.227, Madrid, domingo 22 de mayo de 1898, p. 1 cc. 2-3; cita c. 2.

142. $I b$., c. 3 .

143. E. PARDo BAZÁN, «La vida contemporánea. Margaritas», La Ilustración Artística, a. XVII, n. 883, Barcelona, 28 de noviembre de 1898, p. 762 completa a tres columnas; cita c. 2.

144. De nuevo advirtiéndose: "el filósofo", no el famoso actor teatral. 
lo de la Historia, en opinión de Vico (el filósofo). - No sé si se muerden la cola otras naciones; pero España... ¡ con qué fruición y constancia se entrega á ese significativo sport!

Morderse la cola es sin duda el carlismo, no por ser carlismo,

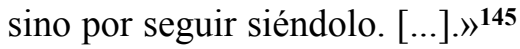

Con no menos afligida frustración que crítica ironía, continúa luego diciendo la ensayista:

«La serpiente que se mordía la cola y que vuelve á mordérsela con furia hoy, engañaba y engaña á quien la contempla: mientras las demás naciones evolucionan, renuevan la historia, cambian de piel, España continúa describiendo la $\mathrm{O}$ enorme, el círculo de la eternidad, como si el siglo no hubiese transcurrido y estuviésemos en los años que precedieron á la muerte de Fernando VII, en los primeros hervores del descontento y de la conjura apostólica.»146

¡Con qué belleza literaria se descalza la condesa de todo conceptualismo abstracto para expresar, con impresionista manera de naturalismo gaélico tan en consonancia con la idea de un 'fatalismo' viquista - la congoja por la repetición del temido acontecimiento fratricida de otra rancia guerra carlista!

«Todos estos pensamientos - más bien melancólicos, y sugeridos por la noticia de un empréstito que nos amaga con una guerra civil- me acudían á la hora en que las últimas gotas de la lluvia temblaban aún en la corola amarilla de las margaritas arbóreas.»>${ }^{\mathbf{1 4 7}}$

Dos meses más tarde, de nuevo La Ilustración Artística (1882-1916) refiere el nombre del napolitano vinculado ahora a la semblanza del reputado académico y jurista, político católico-conservador y catalanista Manuel Durán y Bas (1823-1907). De él nos recuerda Teorodo Baró (1842-1916) que al Catedrático de

145. E. PARdo BAZÁN, op. cit., p. 762, c. 1.

146. $I b$. , c. 2. Los «apostólicos» eran denominados los miembros del sector carlista dividido y separado de los «moderados» a finales de la I Guerra Carlista.

147. $I b$. c. 3. Tres fueron las guerras carlistas en que se enfrentaron los dos bandos, el de los tradicionalistas monárquicos absolutistas y el de los liberales: 1833-1840 (tras la muerte del rey Fernando VII y la proclamación de Isabel II); 1846-1849 (la guerra montemolinista, proclamada por el conde de Montemolín); diferentes alzamientos e intentonas carlistas tuvieron lugar entre 1855 (frente a la Revolución de 1854 que había puesto fin a la Década Moderada y dado inicio al Bienio Progresista) y 1870 (tras un fallido plan de secuestro de Don Carlos) hasta producirse la tercera guerra: 1872-1876. 
Derecho en la Universidad de Barcelona — de la que Durán llegó a Rector en 1896 - y senador vitalicio desde 1891, se le debe un notable ensayo sobre «la teoría del derecho en "La Ciencia nueva de Vico"», publicado en 1861 por la Revista General de Legislación y Jurisprudencia. ${ }^{148}$ Resulta curioso que esta apología de la que se encarga Baró, más o menos por el quincuagésimo aniversario del ingreso como auxiliar en 1850 en la Universidad de Barcelona del egregio catedrático, y cabeza en el país de la Escuela Histórica del Derecho tanto como de la Escuela Jurídica Catalana, coincida con su nombramiento —a los setenta y seis años de edad — de Ministro de Gracia y Justicia dos meses más tarde, el 3 de marzo. Con esta cartera, Durán y Bas formará parte durante algunos meses, ya que dimite durante el mismo año, del primer gabinete de gobierno del conservador Francisco Silvela, designado presidente a raíz del llamado Desastre del ' 98.

También, otra vez de nuevo, Eusebio Díaz González (1878-1968) saca a colación la ejemplaridad histórico-jurídica del «Vico de Nápoles», ${ }^{149}$ ahora en el contexto de una exposición acerca de la justificación de la posición de la Iglesia ante la esclavitud. ${ }^{150}$ En el momento de argumentar el hecho de que «en

148. Teorodo Baró y Sureda, escritor y periodista, político del Partido Liberal (fue elegido diputado a Cortes en cuatro ocasiones entre 1881 y 1895; y nombrado Gobernador civil provincial por 3 veces); miembro de la Real Academia de Buenas Letras de Barcelona, al igual que antes Durán y Bas, y correspondiente de la RAE; fue redactor y director de Crónica de Cataluña y también del Diario de Barcelona. (Cfr. el Db e de la Real Academia de la Historia: http://dbe.rah.es/biografias/7897/teodoro-baro-y-sureda). T. BARÓ, «D. Manuel Durán y Bas», La Ilustración Artística, a. XVIII, n. 889, Barcelona, 9 de enero de 1899, p. 27 a tres columnas (con retrato al centro); ref. a Vico en c. 2. Ciertamente, el estudio de Durán y Bas sobre el derecho en Vico posee una gran envergadura en su tratamiento expositivo y notable profundidad en la línea hermenéutica y explicativa. Fue inicialmente presentado como memoria leída en la Academia de Buenas Letras de Barcelona en la sesión del 29 de abril de 1859, y luego publicada en la RGLJ: cfr. M. DuRÁn y BAS, «La teoría del derecho en la "Ciencia Nueva" de Vico», Revista General de Legislación y Furisprudencia, publicada por D. Pedro Gómez de la Serna y D. José Reus y García, a. IX, t. XIX, Madrid, 1861, pp. 5-21 (véase reproducido el texto en la reedición, conforme al texto original, en Cuadernos sobre Vico, n. 5/6, 1995-96, pp. 459-470, a cargo de J.M. Sevilla y M.A. Pastor). Sobre la recepción de Vico en Durán, cfr. J.M. Sevilla, El espejo de la época, cit., Parte II, cap. II apdo. 5 («La imagen reflectada en el ámbito jurídico (M. Durán y Bas)», pp. 170-176); y también, ID., «Nuevos aportes (históricos y filosóficos) para la fortuna de Vico en el siglo XIX español», Cuadernos sobre Vico, 5/6, 1995-96, pp. 217-236 (sobre Durán y Bas: en apdo. 4, pp. 227-229).

149. Vid. notas 122 y 123 supra.

150. E. Díaz GonZÁlez, «Jesucristo y la humanidad. IV: La esclavitud», El Lábaro. Diario Independiente, a. III, n. 546, Salamanca 18 de enero de 1899, p. 3 cc. 2-5. Argumenta el autor que si la Iglesia no había procurado la inmediata abolición de la esclavitud fue porque, «inspirada en altas razones de conveniencia social, prefirió proceder por evolución á emplear los medios violentos de la revolución»; si bien no cabe duda alguna de que a «la doctrina de Jesucristo» le corresponde «por completo el mérito de la abolición de la esclavitud» (ib., c. 5). 
la culta nación helénica» la consideración acerca de la esclavitud aparezca «legalmente justa y equitativa para eterno baldón de la humanidad», es cuando Díaz se refiere al autor de la Ciencia nuova con objeto de avanzar un paso más en su argumentación: «nos encontramos en la Historia un pueblo que destinado, según Vico de Nápoles, para poseer el mejor Derecho, es considerado por todos como el pueblo legislador por excelencia», aquel que aporta «exactas concepciones jurídicas» inmortalizadas por Papiano, Gayo y otros apreciados jurisconsultos, cuyos códigos «son base fundamental de las leyes modernas». ${ }^{151}$ Mas, no obstante, y a pesar «de tanta perfección y de tanto progreso en la ciencia jurídica», incomprensiblemente esta gloriosa civilización sancionaba la esclavitud como legítima institución en aquella sociedad de aquella época. ${ }^{152}$ Desde luego, así visto, no le servirá Vico a Díaz González para sus pretensiones teodiceicas de trasvasar la lógica histórica del allá y entonces a una pretendida justificación de la lógica histórica del aquí y ahora.

Repite también El Pacense (1891-1899), ahora en su «Folletín», revelando la presencia de Vico cuando publica el ensayo por fascículos en que Eloy Pedrajas y Núñez Romero († 2-7-1913) expone cómo a propósito de la obra del Obispo de Hipona resultó que más tarde acaecieron las modernas filosofías de la historia. El autor, presbítero y desde julio de 1895 distinguido profesor de religión del Instituto General y Técnico de Badajoz, deja impreso en la séptima de las entregas de su Teoría de la belleza y de las bellas artes que la poderosa inteligencia de San Agustín lo mismo se ejercitaba frente a problemas metafísicos, que batallaba frente a las sectas heréticas de los primeros siglos del cristianismo; que lo mismo

«escudriñaba con admirable vista filosófica la naturaleza íntima de lo bello, como echaba las bases de esa, que llaman ciencia novísima, la filosofía de la historia en su inmortal obra "La ciudad de Dios" preliminar soberano, antecedente histórico, fuente de la doctrina abundante donde Bossuet se inspiró para trazar con mano maestra su admirable "discurso sobre la Historia Universal" donde Vico encontró pensamientos para escribir su scienza nuova con sus corsi é ricor$s i$, donde Herder, Hegel, Condorcert [sic] y Krausse [sic] y otros filósofos novísimos, hallaron sin entenderle según su espíritu, la grandiosa ley del progreso que el Cristianismo llevaba en su seno, la mar-

151. Ib., c. 2 .

152. $I b .$, cc. $3-4$. 
cha progresiva y ordenada de la humanidad bajo la acción de la Providencia divina, bajo las aspiraciones previas, é impulsión presente del ideal cristiano.»153

El 25 de mayo de 1899 fallece Emilio Castelar, sin duda una de los principales políticos que haya tenido España, agrandado por su virtuosismo de elocuente orador, su finesse de escritor y su vasto talento intelectual. Como es de suponer, no pocos fueron los panegíricos, artículos de prensa y recordatorios en su honor. ${ }^{154}$ Uno de ellos estuvo a cargo del novelista Jacinto Octavio Picón (1852-1923), ${ }^{155}$ quien al año siguiente de la «nunca suficientemente llorada muerte» de Castelar ocupó la plaza de miembro de número electo de la Real Academia Española dejada vacante por el insigne académico gaditano, y a cuyo elogio y semblanza dedicó todo su discurso de ingreso el académico recipendiario, constestado por Juan Valera (1824-1905). Un extracto del Discurso titulado «Castelar» fue publicado por La Correspondencia de España (1860-1925) en sus ediciones de noche del 24 de junio de 1900 y de mañana del día siguiente; y, ya completo, lo publica más tarde durante ese mismo verano el semanario liberalista El Álbum Ibero-americano (1891-1909). El extenso resumen del dicurso articula citaciones de párrafos salientes del homenaje de Picón al «tribuno de la libertad» y amante de la patria «que a raíz

153. E. Pedrajas y NúÑEz Romero, «Teoría de la belleza y de las bellas artes», en «El Folletín de 'El Pacense'» (7)*, El Pacense. Revista de Enseñanza, a. IX, n. 270, Badajoz, 25 de abril de 1899, p. 2 c. 2. [*El inicio (1) del texto aparece en el folletín del n. 264, de 25 de febrero de 1899; y el cap. VII al que pertenece el texto referido comienza en el n. 269.] Además de pertenecer al Claustro del Instituto de Badajoz, Eloy Pedrajas impartió docencia en el Seminario, antes del Instituto de Enseñanza Media y también posteriormente, hasta que en 1901 ocupó la Cátedra de Religión y Moral en la Normal Superior de Maestros de Badajoz y en 1906 pasó a ser canónigo doctoral de la catedral de Badajoz. Fue miembro de la Real Academia de Buenas Letras de Sevilla. Además de la Teoría de la belleza y de las bellas artes publicó el libro Guadalupe. Impresiones artísticas religiosas (1902). (Sobre la Hoja de Servicios del ilustre sacerdote natural de Cabeza del Buey, puede confrontarse: PILAR Sánchez Pascua, «Afanes por expandir la cultura en la provincia de Badajoz: la formación eclesiástica "pilar" de la segunda enseñanza pública (1600-1900)», Revista de Estudios Extremeños, t. LXX, nº extra, 2014, pp. 477-510; pp. 507-509.)

154. Refiriéndose al «recuerdo de aquel hombre eminente», se llegó a decir que «la prensa había agotado en un año todos los elogios» (José FernáNDEZ BREMÓn, «Crónica General», La Ilustración Española y Americana, a. XLIV, n. XXIV, Madrid, 30 de junio de 1900, 2ª́ página [p. núm. 374] c. 3).

155. Sobre el literato, periodista y académico Jacinto Octavio Picón véanse las páginas del prefacio en su honor leídas por su sucesor, José Francos AndRados, en el sillón letra D de la Academia: Discurso leído ante la Real Academia Española en la recepción pública del Excmo. Sr. D. Fosé Francos Rodríguez el día 16 de noviembre de 1924, Impresor J. Morales, Madrid, 1924. 
de nuestras derrotas le hizo exclamar en una de las últimas cartas que escribió: "Muero de la agonía de España"». ${ }^{\mathbf{1 5 6}}$ Contiene — en el apartado dedicado a reseñar el análisis de «El filósofo y el estilista»— el repaso de autores favoritos de Castelar y de la convicción de Picón de que las ideas filosóficas del homenajeado tienen más hondura en sus estudios históricos que en los filosóficos. Es ahí cuando el periódico, en su crónica, citando un fragmento del discurso de Picón, expone:

\begin{abstract}
«Yo no me atreveré á decir que pueda hoy designarse á Castelar como dechado de historiadores, porque sé que está en tela de juicio si la historia $[\ldots]$ ha de ser meramente expositiva ó ha de procurar en ella que del examen de los hechos se desprenda la crítica de las ideas que lo produjeron; si se encamina a conocer el desarrollo de las ideas mismas, apreciando los sucesos como sus consecuencias ineludibles; si ha de ser considerada sólo como experiencia viva y dolorosa; mediante la cual va purificándose la conciencia humana, ó si hemos de reconocer y admirar en su desenvolvimiento la presencia eterna de Dios; pero si la historia, ya se sujete al principio filosófico de Vico y de Herder, ya al providencialismo de Orosio, San Agustín y Bossuet, ha de ser siempre, como dijo Cervantes con la intuición sintética de los grandes poetas: "testigo de lo pasado, ejemplo y aviso de lo presente y advertencia de lo porvenir", entonces sí me arriesgo á decir que Castelar poseyó el concepto exacto de la historia [...]».157
\end{abstract}

156. «En la ACAdemia española. Recepción de Jacinto Octavio Picón», La Correspondencia de España. Diario político independiente y de noticias, a. LI, n. 15.482, Madrid, domingo 24 de junio de 1900 (edición de noche), y n. 15.483, lunes 25 junio 1900 (edición de mañana), p. 1 cc. 3-6 y p. 2 cc. 1-3. Contiene también el extracto del discurso de contestación de Juan Valera, en p. 2 cc. 2-3. Cfr. el discurso completo de Picón y la contestación en: «En la ACADEMIA ESPAÑOLA. Discurso de recepción de D. Jacinto Octavio Picón», El Álbum Ibero-americano, a. XVIII, n. 30, Madrid, 14 de agosto de 1900, pp. $2^{\text {a }}-5^{\text {a }}$ (numeradas pp. 350-353 a tres columnas); cita p. 351 c. 1. El Discurso se continúa en los dos números siguientes: n. 31 correspondiente al 22 de agosto, pp. $2^{\mathrm{a}}-5^{\mathrm{a}}$ (numeradas $\left.362-365\right)$, y n. 32 el 30 del mismo mes, pp. $4^{\text {a }}-5^{\text {a }}$ (pp. 376-377), y da comienzo la «Contestación del Excmo Sr. D. Juan Valera» en la $5^{\text {a }}$ página (p. 377) hasta la $8^{\mathrm{a}}$ (p. 380), para concluir en el número siguiente del 7 de septiembre, pp. $2^{\text {a }}-5^{\text {a }}$ (pp. 386-389). El Álbum Ibero-americano era un semanario ilustrado de carácter hispanoamericanista y con importantes aspectos feministas por estar vinculada a éste la periodista Concepción Gimeno de Flaquer (llamada C. Gimeno y Gil, 1850-1919; fue editora de La mujer y directora de La Ilustración de la Mujer; y finalmente de El Álbum de la Mujer, desde 1883 hasta 1890, iniciando en 1891 con su marido el proyecto del Álbum Ibero-americano, que concluirá en 1909).

157. Ib., p. 1 c. 6 de La Correspondencia de España, cit., y p. 353 c. 1 de El Álbum Ibero-americano, también citado. Hemos revisado diversos periódicos de los días 24 y 25 de junio que recogen la noticia de la RAE y/o publican extracto del Discurso de Picón — así, p.e., La Época, El Heraldo de Madrid, El Liberal, etc.-, pero no recogen la referencia a Vico hecha por el nuevo académico. 
Aparece Vico también citado a propósito de la nueva reforma de la debatida Ley del Servicio Militar Obligatorio, que en el Parlamento se trataba de defender —así el mismo Castelar, ${ }^{158}$ no menos que el radicalista Pi y Margall- eliminando la tradicional exclusión del servicio militar por «la redencion á metálico» y la sustitución subrogada, medios que eran muy utilizados para librarse de la guerra, con un significativo alto número durante el conflicto de Cuba. ${ }^{159}$ En este contexto, el diario gerundense La Lucha (18711910) y el tarraconense La Opinión (1875-1904), así como el semanario independiente La Nación Militar (1899-1912) publican durante el mes de septiembre un artículo tomado del Diario de Barcelona (1792-1994 [dig. 2009]) dado a luz unos días antes firmado bajo la sigla "J.". El anónimo pero bien informado comentarista defiende, precisamente a la contra del servicio obligatorio, que lo importante no es llevar a todo el mundo al cuartel, sin distinción ni posibilidad de "redención", sino proporcionarles a todos los mozos la instrucción militar correspondiente y, en caso de guerra, decretar la movilización general. De este modo, frente a las posiciones igualitaristas, tachadas por "J." de radicalismo intransigente que abanderan el lema revolucionario francés de «Un hombre no es más que un fusil», el artículo esgrime el siguiente razonamiento liberal-conservador:

«Pero el tiempo, que no es siempre factor de adelantos y que parece empeñarse frecuentemente en dar carta de naturaleza á la teoría de Vico, ha resucitado ahora, en España sobre todo, la desacreditada propaganda de soluciones extremas con arreglo á las cuales debe desaparecer en absoluto todo lo que no sea el concurso personal de cada ciudadano en la noble empresa de garantizar la seguridad de Estado.

Desde nuestras recientes guerras coloniales, el argumento se ha repetido hasta la saciedad: los ricos deben sufrir las mismas fatigas é

\footnotetext{
158. Véase el famoso discurso de Castelar en el Congreso a favor del servicio militar obligatorio como principio democrático hacia la patria de - a imagen de Roma- un «ejército de ciudadanos» frente al -imagen de Cartago- «ejército de mercenarios»; imágenes evocadas por el «gran historiador Juan Bautista Vico» y su idea de «que la historia de Roma es como la escuela de la humanidad». Discurso publicado al menos por El pueblo español y por La Época en Madrid el 14 de diciembre de 1876. Véase nuestra Ad. IV «"Aludir con la palabra Vico". Nuevas ráfagas viquianas ...», cit., p. 35. El Discurso de Castelar está recogido en el n. 145 del Diario de sesiones de las Cortes de 13 de diciembre de 1876 (pp. 4.029-4.032).

159. En cifras, 23.284 en 1898 y 8.173 en 1899; además de los cerca de 8.000 objetores en 1898, muchos de ellos desertores a Portugal, Francia, África y América (cfr. https://almirantecervera.com/ la-espanade-1898/el-servicio-militar-y-la-redencion-en-metalico/ web creada por el historiador militar Dr. Ángel L. Cervera Fantoni).
} 
idénticos peligros que los menos favorecidos por la suerte, á fin de que el sacrificio de la libertad, de la salud y de la vida que á éstos impone el servicio de guarnición ó el que se presta en el campo de batalla, alcance por igual á todos los españoles sin escepción de personas ni calidades, esto es, sin diferencia alguna "de bolsillos"». ${ }^{160}$

De nuevo La Correspondencia de España recuerda a Vico, esta vez en el número extraordinario por el fin de siglo y la entrada del nuevo. Número con unas primeras páginas continentes de análisis y augurios históricos firmados por Pi y Margall, el Marqués del Vadillo, López Domínguez, Romero y Robledo, Ugarte, Soldevilla, Verdes Montenegro, Dato, etc.; destacando entre tanta gente ilustre e importante la firma del filósofo krausopositivista $-\mathrm{y}$ diputado parlamentario en 1881 por el Partido Republicano- Urbano González Serrano (1848-1904). El heterodoxo discípulo de Nicolás Salmerón y de Francisco Giner de los Ríos titula su columna «El nuevo siglo». Ciertamente un título adecuado, porque en vez de hablar del pasado siglo González Serrano mira hacia adelante, con una mirada sociológica más que política a la hora de desvelar el rol del socialismo en ese siglo que comienza su andadura por senda peligrosa girando en torno al «problema de los problemas»: el social. «¿Cómo convertir la preñez de peligros en fecundidad de auroras?», se pregunta poéticamente el krausista: transformando el socialismo de «grito de guerra», y lucha de una clase, en ideología influyente en la política reformadora de la realidad social. Para ello, afirma González Urbano que antes habrá de dar el socialismo la batalla en el campo de la ciencia que indaga la vida social, yendo de la mano del método adecuado: el sociológico. Porque la sociología, «más que una ciencia, es un proceso que orienta todo el saber hacia nuevas direcciones, recurre al método genético e histórico evolutivo». ${ }^{\mathbf{1 6 1}}$ No en vano es, junto con su coetáneo Manuel Sales Ferrer

160. J., «El servicio militar obligatorio», La Lucha, a. XXX, n. 7.163, Gerona, miércoles 19 de septiembre de 1900, p. 1 c. 4 y p. 2 c. 1-3; cita p. 2 c. 2 . Ib. en La Opinión. Diario político de avisos y noticias, a. XXVI, n. 215, Tarragona, miércoles 19 de septiembre de 1900, p. 1 c. 1-3; cita en c. 3. Ib. en La Nación Militar, Semanario independiente, de Ciencias Sociales y Militares, Literatura y Artes, a. II, n. 92, 30 de septiembre de 1900 (dedicado a la memoria del general Arsenio Martínez Campos), pp. 742743; cita p. 743 c. 1. Dice el semanario militar — que inició su andadura editorial tras el Desastre del '98-, en una breve introducción a la transcripción del artículo tomado del decano de la prensa catalana, que «se atribuye este trabajo á una personalidad saliente de la política, que tiene desde hace tiempo la confianza de los señores presidente del Gobierno y ministro de la Guerra»; si bien es cierto que el autor «parece bien enterado, y que resume perfectamente los argumentos que se oponen á la adopción pura y simple del servicio obligatorio» (La Nación Militar, cit., p. 742 c. 2).

161. U. GONZALEZ SERRANO, «El nuevo siglo», La Correspondencia de España, 31 de diciembre de 1900 - 1 de enero de 1901, p. 1 c. 4. Afirma González Serrano que el método genético-histórico rechaza «el 
(1843-1910), difusor en España de la moderna sociología científica. Ciencia modesta y enemiga de «la inercia mental», la sociología va de los datos de los «hechos-tipos» a la indagación reflexiva, es decir, se conduce de los hechos a las ideas, y de tal modo: «el sociólogo señala discretamente el límite que separa lo infinito del querer de lo condicionado del poder, y que distancia lo posible de lo imposible, la utopía del ideal práctico ó de acción». ${ }^{\mathbf{1 6 2}}$ Ese camino le viene declarado al socialismo militante por su propia evolución, el cual Urbano González Serrano fija al «ideal práctico» de reformas demandadas por la propia época, por el espíritu del tiempo propio; una evolución que el filósofo sociológico y socialista fija al papel con que finaliza su escrito a modo de consigna:

«Que evolución tan fecunda enseñe á las clases directoras que ni es buen consejero el miedo, ni vale contra los gritos de los que demandan justicia un terror que comienza por no compadecerse con el espíritu y las costumbres del tiempo. Pero á la vez que recuerden que el ideal cumplido es realidad venida á menos y que exige, contra la inmovilidad, signo de muerte, concepción de otro nuevo; tejer y destejer continuos (que le hacían pensar á Vico, juzgando solo por apariencias en su corsi e ricorsi), en cuyos entresijos y entrañas late la fuerza de la vida y el impulso para su desarrollo.»163

Si el argumento de Urbano González Serrano aquí expuesto transita desde un siglo que ha sido prolífico en derramamiento de sangre a punta de bayonetas y fuerza de hechos consumados, hacia un siglo en el que habría de imperar «la fuerza incoercible de las ideas» dirigiendo de modo pacífico e incruento la lucha de clases, no menos parece insistir el sociólogo krausista en reiterar en el mismo periódico, transcurrido ya el primer verano del nuevo siglo, el mismo problema y en los mismos términos. Sucede cuando a propósito de un discurso de Costa - mantenedor de los Juegos Florales de Salamanca- viene a comentar González Serrano, instado ante las tres fórmulas de colectivismo propuestas por Costa para abordar el problema social agrario, que éstas resultan fórmulas ya anticuadas hoy, que

\footnotetext{
individualismo revolucionario con su violenta y anárquica protesta» y «los formalismos vacíos», además de que se «opone al materialismo económico, según el cual concibe C. Marx la historia humana» (ibíd.). Sobre Vico y González Serrano cfr. dos ligeros apuntes en El espejo de la época, cit., p. 98 y en la Adenda IV «"Aludir con la palabra Vico”. Nuevas ráfagas viquianas ...», cit., p. 42.

162. $I b . .$, p. 1 c. 5.

163. $I b$.
} 
«si respondieron á necesidades de época, son insuficientes, por varias razones; la principal, porque el enigma de los enigmas, el problema social de hoy, es más complejo que el antiguo del pauperismo, y la muy atendible de que los conflictos sociales, si se reproducen en la historia, no se repiten uniformemente, como pensaba Vico, en sus corsi y ricorsi (círculos). Semilla para recoger el fruto es lo que se necesita, y la semilla es la reorganización política, de la cual brote la social. Inculpe Costa á los que han menospreciado la primera, presumiendo que sin ella se podía obtener la segunda.»164

También a propósito de Juegos se pronuncia la Redacción del Noticiero Salmantino (1898-1904) cuando analiza los simbolismos de los juegos olímpicos de la antigua Grecia para, de camino, rememorar la independencia griega en el pasado siglo y la generosidad de Europa para con la vieja hermana de la familia. En ese contexto periodístico, sin embargo, la intención del Noticiero salmantino es exponer cómo se otorga significado al restablecimiento de unas nuevas olimpiadas, ya más internacionales que helenas, si bien aquéllas significarían la resurrección de bellas y admirables antichità griegas, que diría Vico, no en vano citado el napolitano en el tramo conclusivo del editorial del periódico:

«La teoría de Vico de que los acontecimientos se repiten y la historia de la humanidad es un círculo, se confirma frecuentemente, y así como apenas existen verdaderas / novedades, de la misma suerte reaparecen, cuando menos se piensa, las olvidadas costumbres.

Los griegos hacen bien en resucitar sus antigüedades, que son gloriosísimas y que jamás olvidarán los que están bien persuadidos de su belleza.»165

Durante el primer año del siglo XX también imprimen la huella del nombre de Vico los diarios republicanos La Región Extremeña (1863-1920), de Badajoz, y El Liberal (1881-), de Mahón. El primero lo hace dentro de una ácida crítica del periodista krausista Alfredo Calderón (1850-1907) ${ }^{\mathbf{1 6 6}}$ hacia

164. U. González Serrano, «Los juegos florales», La Correspondencia de España, a. LII, n. 15.948, Madrid, domingo 6 de octubre de 1901, Hoja Suplementaria al n. 15.948, p. 3 cc. 1-2; cita c. 2.

165. [ ], Noticiero Salmantino. Diario imparcial de la noche, a. IV, n. 1.198, Salamanca, miércoles, 3 de julio de 1901, p. 1 cc. 1-4; en cc. 3-4. (En cabecera del periódico: «10 ediciones diarias»; citada la de la tarde).

166. Discípulo de Julián Sanz del Río y de Fernando de Castro, el madrileño Alfredo Calderón y Arana (1850-1907) estuvo vinculado a la enseñanza con Giner de los Ríos y a la ILE. Cfr. ANTONIO HEREDIA, «El krausismo español», en Cuatro ensayos de historia de España, Edicusa, Madrid, 1975, p. 394. Calderón destacó como periodista militante laico y republicano, y durante la Restauración combatió con su pluma al régimen. 
quienes por dejación y decadencia han derivado en vano nombre de lo bello a «erigir á la moda en criterio sumo de la verdad y el bien», como hacen «unos cuantos Petronios de sotana» erigidos en árbitros de la elegancia en el cielo de la cursilería. Sin embargo, lo que desvela de fondo Calderón es que tanto en la acción estética como en la ética se condujo un ataque reaccionario al liberalismo, no ya frontal moralmente ni por dogmas de fe o creencias, sino por cuestiones de gusto. La estrategia, a juicio de Calderón, se fundamenta en un relativismo de lo cursi sobre la condición subjetiva de lo elegante. Los «nuevos apóstoles» condenaron la herejía sólo por vieja, y se «anatemizó el liberalismo, no por pecaminoso, sino por schoking»; y se hizo ver cursi el «ser liberal» o «ser republicano». «El buen gusto sustituyó á los artículos de la fé. El buen tono se constituyó en el primero de los Mandamientos. Y hubo devociones, templos santos, Padres de moda». No dice Calderón que todas las épocas tienen sus Popes, como bien sabemos y sufrimos, porque él está enfrascado en la suya propia frente a ese neoclericalismo estratega en la estigmatización que el «cursilismo», a falta de elegancia, arremete contra la independencia de criterio, la convicción, la sinceridad... como si tales valores éticos fueran groserías estéticas. Una «cruzada degradante y corruptora en que han coincidido eclesiásticos sagaces y políticos podridos», que entroniza «la negra reacción, madre de la miseria, la ruina, la sangre y la mugre» y que, cual imagen de la circularidad viquiana de la historia, no hacen sino repetir tanto la mediocridad y la insustancialidad como «el cretinismo» y la impostura.

«La moda es voluble, pero monótona en sus cambios. Reducida á muy limitada esfera de posibles variaciones, se repite con desesperante uniformidad, girando en el círculo de hierro en que pretendió el pensador Vico encerrar la evolución entera de la historia. [...] La moda reaccionaria no ha sido más que un atavismo. Desechó la casaca de Voltaire para endosar el sayal de Torquemada. [...] Cerró por añeja la Enciclopedia, para enfrascarse en la Summa. Con arreglo á su figurín, el alma de la patria resulta vestida de rigurosa Edad Media.» ${ }^{\mathbf{1 6 7}}$

167. A. Calderón, «Lo cursi», La Región Extremeña. Diario Republicano, continuación de La Crónica, a. XXXVIII [errata en la portada que dice «Año XXXXIII»], n. 4.810, Badajoz, jueves 14 de febrero de 1901, p. 1, c. 1-3; cita sangrada de c. 2. 
Y vuelta a empezar. Tal y como vuelve de nuevo Calderón a describir meses más tarde, en su artículo «Atavismo». Éste es tomado del diario republicano barcelonés La Publicidad (1878-1922) por El Liberal balear — que llena la primera con cuatro columnas en portada - y de nuevo a su vez por La Región Extremeña ${ }^{\mathbf{1 6 8}}$ No sólo cita a Vico como autoridad, sino que todo el escrito del krausopositivista madrileño (una reflexión sobre la tradición histórica del terrorismo y los asesinatos políticos — nihil novum sub sole-) destila viquismo entre los poros de sus caracteres tipográficos. «El pasado resucita; los muertos vuelven», dice el pensador krausista. «Problemas que parecían definitivamente resueltos, se suscitan de nuevo en estos pueblos latinos, los más hondamente convertidos por las revoluciones». ${ }^{169}$ Del molde del fanatismo religioso salen fanatismos ideológicos. Resulta obvio que deba de pensarlo así un positivista como Calderón, que probablemente asumirá la doctrina comteana de los tres estadios. «Un fanatismo redivivo restaura para nosotros aquellos días turbados que sucedieron á la Reforma. Diríase que estamos en vísperas de otra guerra [...]», profetiza recién inaugurado el siglo en el cual, sólo en su primera mitad, sufrirá dos Guerras Mundiales. Un hastiado «espíritu contemporáneo» que no acierta a creer en algo nuevo y es incapaz de renovar su fluido vital moral, retorna endeble al pasado. Nada más evidente que la decadencia de Occidente, advertida en una fenomenología del abismo que muestra cómo «Ninguna esfera de la humana actividad puede sustraerse á ese ambiente de regresión atávica que hoy invade el medio moral, como un hálito del sepulcro.» ${ }^{\mathbf{1 7 0}}$ Menos aún en el orden de la cultura: «Las creaciones contemporáneas son frutos de la cópula entre la impotencia y el tedio.» ${ }^{171}$ Es en este clímax literario descriptivo del barbarismo de la reflexión y de la quiebra de los pilares de la civilización contemporánea cuando, de nuevo como hizo anteriormente en febrero, Calderón rememora al filósofo napolitano, esta vez con una llamada conclusiva de las tres columnas de denso, erudito y bello texto:

168. A. Galderón, «Atavismos», La Publicidad, edición de la mañana, a. XXIV, n. 6.259, Barcelona, miércoles 18 de septiembre de 1901, p. 1 cc. 4-5. ID., «Atavismos», El Liberal. Diario de Unión republicana, a. 21, n. 6.070, Mahón, sábado 21 de septiembre de 1901, p. 1 cc. 1-4. ID., «Atavismos», La Región Extremeña. Diario Republicano, continuación de La Crónica, a. XXXVIII, n. 4.104, Badajoz, martes 24 de septiembre de 1901, p. 1, cc. 1-3.

169. Ib., cita en La Publicidad, p. 1 c. 5; El Liberal, p. 1 c. 3; y La Región Extremeña, p. 1 c. 2.

170. $I b$.

171. Ib., cita en La Publicidad, p. 1 c. 5; El Liberal, p. 1 c. 4; y La Región Extremeña, p. 1 c. 3. 
«¿Será este visible agotamiento, símbolo hipócrita de una civilización que muere? ¿Estará destinada la nuestra á hundirse tambien en el abismo de la degeneración en que tantas otras cayeron? ¿Tendría razón Vico, el historiador filósofo, al afirmar que la especie humana se halla condenada á dar eternamente vueltas dentro de un mismo círculo, á modo de mula de noria? ¡Quién sabe!»\$172

En cualquier caso, está claro que ante estadios históricos de barbarie, crueldad, ignorancia y superstición, que frente a épocas de cobardía, indiferencia y servilismo, Calderón pone su talento y su pluma - bien como escritor filosófico (o sociológico), bien como filósofo periodista y cronista de la humanidad - contra «todo el hediondo envilecimiento en que vivimos»:

«La pluma ha de ser en nuestras manos espada que hiera, maza que aplaste, escoba que barra. [...]: combatir escribiendo. [...] Hoy la pluma es investidura, es magisterio, es apostolado. ¿Para qué escribir sino [sic]?»»173

Si el siglo XIX finaliza con la marea del desastre noventayochista, que se adentra como afluente en el caudal del nuevo siglo hasta 1902 — tan sólo cuatro años después - , aquello que ahora cambia no es sólo el espíritu respecto del «problema social», como denuncia Calderón, sino el debilitamiento del Estado de la Restauración, al alza el afán regeneracionista, la crisis de las oligarquías y el ascenso de las ideologías pequeño-burguesas del Estado democrático liberal y de las ideologías obreras del Estado socialista del proletariado, el empoderamiento de los regionalismos, el último gobierno de la Regencia abortado de una profunda crisis - y el advenimiento del nuevo monarca tras cumplir su mayoría de edad a los diceciséis años... El 29 de noviembre de 1901 muere Pi y Margall, figura del republicanismo federal, presidente efímero del gobierno ejecutivo de la I República, y convencido progresista y antimonárquico. El 17 de mayo de 1092 Alfonso XIII jura la Constitución, y reinará en España hasta la proclamación de la II República el 14 de abril de 1931. En este tramo histórico que ahora comienza, poco o al menos relevante hallamos sobre el historiador filósofo Vico —en definición de Calderón- en la prensa periódica española. No ha desaparecido el napolitano, y más que probable segura-

172. $I b$.

173. A. CaLderón, «Los deberes de la pluma», La Publicidad, edición de la mañana, a. XXIII, n. 7.835, Barcelona, viernes 26 de octubre de 1900, p. 1 cc. 2-3; cita c. 3. 
mente no hayamos descubierto por ahora otras nuevas vetas en el rastreo de la multitud de diarios publicados, que esperamos — siguiendo ese rastreo historiográfico y abriendo cada vez más el espectro de cabeceras periodísticas analizadas - irán siendo completadas en posteriores y continuadas Adendas o en indagaciones complementarias de nuevos investigadores.

Quedan como ejemplo cuatro o cinco pequeñas recepciones de Vico. Una de ellas a final del año 1901 en la lista de temas y premios del Certamen de la Academia Jurídico-escolar de Valencia, noticiada en el Diario de Valencia Las Provincias (1866-), refiriéndose entre los premiados y bajo el número 23 al catedrático de Economía Política y Estadística y Hacienda Pública, de la Universidad de Valencia, Dr. Melchor Salvá Hormaechea (1834-1918), ${ }^{174}$ con un tema dedicado a la doctrina de Vico de que el principio regulador del Derecho se basa en una razón. ${ }^{175}$ Pero el espectro de recepciones de Vico, como casi siempre divididas entre prensa progresista y prensa conservadora, la mayoría de veces suele remitir a la doctrina de la circularidad de la historia. Porque es la repetición el concepto que martillea en la mente de los periodistas y cronistas ocupados en el tema de su tiempo. Así, por ejemplo, una réplica de "Chinita" a sus compañeros de tabloide, en la que para defender los libros por él recomendados les recuerda que ésos «nos enseñan los misterios del yo y el no yo, principios fundamentales como el de contradicción ó / como el sentado por Descartes con su duda metódica al decir y demostrar brillantemente "yo

174. Natural de Pamplona, doctorado en Derecho en la Universidad Central en 1858. Catedrático de Elementos de Economía Política y Estadística de la Universidad de Santiago en 1858; cátedra que continuó ocupando en la Universidad Central de Madrid desde su traslado en 1860. Catedrático de Ampliación de Derecho Mercantil y Penal y Economía Política y Estadística en la Universidad de Santiago en 1867. Catedrático de Legislación Comparada de la Universidad Central en 1876. Catedrático de Economía Política y Estadística y Hacienda Pública de la Universidad de Valencia desde 1896. Se jubiló en 1903. Era desde 1872 académico de la Real Academia de Ciencias Morales y Políticas. Cfr. PAREs Portal de Archivos Españoles, Ministerio de Cultura y Deporte http://pares.mcu. es/ParesBusquedas20/catalogo/autoridad/68191

175. «23.-Del Dr. D. Melchor Salvá, catedrático.-Tema: «Significado de la palabra derecho en general. Doctrina de Vico sobre que el principio regulador se basa en la razón infinita de Dios. Si el Estado solo declara el Derecho preexistente. Los tres modos con que el estado procura y aplica el derecho, previniendo, imperando y juzgando. Reseña histórica de las doctrinas acerca de la noción del Derecho desde Platón, fijándose particularmente en las de Vico y Gioberti.-Premio: Una obra de Derecho.» En «Academia Jurídico-escolar-Temas y premios del Certamen», Las Provincias, a. XXXVI, n. 12.901, Valencia, domingo 22 de diciembre de 1901, p. 3 c. 2. (Periódico de orientación regionalista y conservadora, Las Provincias se publicó desde 1866 hasta 1936, y tras el periodo de la Guerra Civil continuó en 1939, hasta hoy). 
pienso; luego existo" ó como Vico al creer verdadero lo hecho por él y..... basta, dirás [...]». ${ }^{176}$ Igualmente un comentario del Comandante de Ingenieros Francisco del Río Joan, en la publicación decenal de tipo técnico Madrid Científico (1897-1936), dentro de uno de los muchos artículos acerca de la electricidad (que, como elemento civilizatorio y de progreso, fue un proceso muy vinculado al inicio del reinado ejecutivo de Alfonso XIII). Río Joan, autor de varios artículos y ensayos sobre el novedoso mundo de la electricidad y su significativo avance para el desarrollo de la humanidad, se pregunta en «El proceso de la electricidad» qué nos es dable imaginar una vez que hemos alcanzado estas altísimas cotas de infinito progreso gracias a la energía eléctrica:

«¿Volveremos por estertores cósmicos, al hombre troglodita para cumplir así la ley palingenésica de Vico, ó serán las ráfagas cometarias de Lockyer las que ahogue nuestro afán desapoderado, destruyendo las actuales formas biológicas, ó retornándonos á la edad de las cavernas? ;Chi lo sa!»». ${ }^{177}$

Por su lado, El Progreso de Asturias (1901-1905), ${ }^{178}$ diario ovetense de tendencia republicana liberal, dice en la primera de las entregas dedicadas al tema de la pena de muerte que: «El historiador Vico no pudo encontrar en los tiempos medios un círculo histórico; no pudo ver una reproducción progresiva de la filosofía antigua.»> ${ }^{\mathbf{1 7 9}}$

Por último, traemos a colación una inclusión dramatúrgica de referencia a Vico, de nuevo en orden cómico, esta vez en Gente Vieja (1900$1905)^{180}$ y a propósito de unos «Fragmentos de una comedia inédita, con tesis y todo, contra el divorcio», epítome con que se subtitula el cuadro en tres

176. Chinita, «Cartas abiertas. - Chinita á sus compañeros», La Provincia. Semanario conservador, a. IV, n. 175, Soria, 24 de junio de 1902, pp. 2-3; cita p. 2 cc. 3-4 y p. 3 c. 1. Vinculado al Partido Conservador soriano, La Provincia comenzó a publicarse el 3 de octubre de 1899.

177. F. DEL Río JoAn, «El Mundo Eléctrico - El proceso de la Electricidad», Madrid Científico, a. IX, n. 396, Madrid, 1902, pp. 275-278 a dos columnas; cita p. 278 c. 2. A partir de 1917 la publicación pasó a ser quincenal.

178. Cfr. Florencio Friera Suárez, «Colaboraciones de Ramón Pérez de Ayala en El Progreso de Asturias», Moenia, n. 18, 2012, pp. 95-149; p. 97 y nota 3.

179. [ ], «La pena de muerte» (I), El Progreso de Asturias, a. II, n. 330, Oviedo, martes 3 de junio de 1902, p. 1 c. 4.

180. Publicación decenal — fundada y dirigida por el literato Juan Valero de Tornos (1842-1905)— fuertemente antimodernista, al igual que el ya citado Madrid cómico, y desde el costumbrismo y casticismo contraria al decadentismo tanto político como estético propios del fin de siglo. La cabecera se abre con una lista de algo menos un centenar de «los mozos viejos que escriben en Gente Vieja» (entre ellos el más tarde presi- 
actos de Cenizas de amor, firmado por F. Díaz Gallo. ${ }^{181}$ De nuevo el círculo de Vico emerge en boca de personajes ficticios. Ahora, en un fragmento del acto I, en una escena entre Fernando, personaje del amigo, y Luis, protagonista del marido en crisis de Aurora:

«FER. El tiempo te hará volver

de tu lastimoso error, renaciendo aquel amor

que tuviste á tu mujer.

LuIs. "Como no muele el molino

con el agua que ha pasado, así el amor que ha olvidado,

no toma el mismo camino"

dice Lope; y si esto llega

en nuestra ventura corta,

se acabó.....

FER. ¿Y eso qué importa?

Pues yerra Lope de Vega.

En círculo hasta la Historia

gira siempre sin cesar.

LuIs. ¿Y el corazón ha de dar

también vueltas como noria?

¡Nada no te canses, chico;

será sin duda un dolor,

pero lo que es en amor

falla el sistema de Vico!

FER. Aunque eso digas ahora,

al cabo es sólo decir, y no has de poder vivir

sin tu mitad, sin Aurora.

LuIS. ¡Muy bien!

FER. $\quad$ Pues no eres sincero.» ${ }^{\mathbf{1 8 2}}$

Cerramos con esta publicación el año inicial de Alfonso XIII, y el sistema de Vico a 31 de diciembre de 1902.

dente de la II República, Manuel Azaña, que introducido por su tío materno Félix Díaz Gallo —citado aquí- comenzó sus colaboraciones en el semanario bajo el pseudónimo de «Salvador Rodrigo»).

181. Félix Díaz Gallo y Muguruza (1840 ca.-i??), Doctor en Derecho.

182. F. Díaz Gallo, «Cenizas de amor - Fragmentos de una comedia inédita, con tesis y todo, contra el divorcio», Gente Vieja. Ecos del siglo pasado, siglo II, a. III, n. 73, Madrid, 31 de diciembre de 1902, pp. 3-4 a tres columnas; cita p. 3 c. 2. 